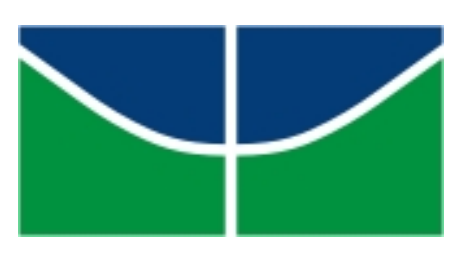

UNIVERSIDADE DE BRASÍLIA - UNB

FACULDADE DE DIREITO

EDMUNDO BELARMINO RIBEIRO DOS ANJOS

ESTADO EMPREENDEDOR E O REGIME JURÍDICOADMINISTRATIVO DAS PARCERIAS PÚBLICO-PRIVADAS EM CIÊNCIA, TECNOLOGIA E INOVAÇÃO 
EDMUNDO BELARMINO RIBEIRO DOS ANJOS

ESTADO EMPREENDEDOR E O REGIME JURÍDICOADMINISTRATIVO DAS PARCERIAS PÚBLICO-PRIVADAS EM CIÊNCIA, TECNOLOGIA E INOVAÇÃO

Dissertação apresentada como requisito parcial para obtenção do grau de Mestre, no Programa de Pós-Graduação da Faculdade de Direito da Universidade de Brasília, linha de pesquisa "Transformações na Ordem Social e Econômica e Regulação".

Orientador: Prof. Dr. Márcio Nunes Iorio Aranha Oliveira

Brasília, janeiro de 2017. 
FOLHA DE APROVAÇÃO

EDMUNDO BELARMINO RIBEIRO DOS ANJOS

\section{ESTADO EMPREENDEDOR E O REGIME JURÍDICO-ADMINISTRATIVO DAS PARCERIAS PÚBLICO-PRIVADAS EM CIÊNCIA, TECNOLOGIA E INOVAÇÃO}

Dissertação apresentada como requisito parcial para obtenção do grau de Mestre, no Programa de Pós-Graduação da Faculdade de Direito da Universidade de Brasília, linha de pesquisa "Transformações na Ordem Social e Econômica e Regulação".

Aprovada em: de de

BANCA EXAMINADORA

Prof. Dr. Márcio Nunes Iorio Aranha Oliveira (Orientador - Presidente)

Dr ${ }^{\mathbf{a}}$. Simone Henriqueta Cossetin Scholze

(Membro externo - Ministério da Ciência, Tecnologia, Inovações e Comunicações)

Prof $^{\mathrm{a}}$. Dr ${ }^{\mathrm{a}}$. Ana Frazão Vieira de Mello (Membro - UnB)

Prof. Dr. Othon de Azevedo Lopes (Suplente - UnB) 


\section{FICHA CATALOGRÁFICA}

\section{ANJOS, EDMUNDO BELARMINO RIBEIRO DOS}

Estado Empreendedor e o Regime Jurídico-Administrativo das Parcerias PúblicoPrivadas em Ciência, Tecnologia e Inovação. orientador Márcio Nunes Iorio Aranha Oliveira. Brasília, 2017.

xii, 129 p., 210 x 297 mm (FD/UnB), Mestre, Dissertação de Mestrado - Universidade de Brasília, 2017.

Faculdade de Direito

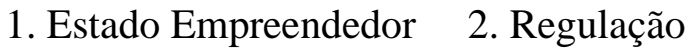

3. Lei de Inovação $\quad$ 4. Parcerias público-privadas em P\&D

$\begin{array}{ll}\text { I. FD/UnB II. Título } & \end{array}$

\section{REFERÊNCIA BIBLIOGRÁFICA}

ANJOS, E. B. R. dos (2017). Estado Empreendedor e o Regime JurídicoAdministrativo das Parcerias Público-Privadas em Ciência, Tecnologia e Inovação. Dissertação de Mestrado em Direito, Faculdade de Direito, Universidade de Brasília, Brasília, DF, $129 \mathrm{p}$. 


\section{AGRADECIMENTOS}

Agradeço à minha esposa, Patricia Cruz, a quem dedico este trabalho, por ter sido a grande incentivadora do meu ingresso no mestrado e pela torcida e presença constantes durante todo o curso.

Aos meus pais, Tarciso e Dilma, pela torcida e incentivos de hoje e de sempre.

Ao Prof. Dr. Márcio Iorio Aranha, meu orientador e professor no mestrado, pelas valiosas lições ao longo do curso e pela orientação competente e profissional que me foi concedida.

Agradeço, por fim, à Drª. Simone Scholze e aos Professores Drª . Ana Frazão e Dr. Othon de Azevedo Lopes, por gentilmente aceitarem o convite de participar da banca de mestrado.

Muito obrigado! 


\section{RESUMO}

Este trabalho tem como objetivo apontar os elementos conceituais do Estado Empreendedor e identificá-los no texto constitucional, com o intuito de fornecer dados teóricos para uma avaliação jurídica crítica de políticas industriais e de desenvolvimento da ciência, tecnologia e inovação. É aprofundado o conceito de Estado Empreendedor introduzido por Mariana Mazzucato (2014) e explorado o texto constitucional brasileiro para identificar os elementos conceituais desse modelo de Estado. Sustenta-se que a Constituição Federal do Brasil adotou o modelo de Estado Empreendedor para a regulação da ciência, tecnologia, inovação e do desenvolvimento industrial, de modo que as políticas públicas direcionadas a esses setores deverão ter a regulação do Estado como pressuposto, com o fim de promoção do desenvolvimento nacional sustentável. O Estado Empreendedor é concebido como uma dimensão do Estado Regulador e tem como umas de suas principais consequências a refutação de concepções teóricas que defendem o afastamento da regulação estatal sobre os mercados e a aceitação de políticas de desenvolvimento que valorizem as características locais do país. No trabalho também é sustentado que a Lei de Inovação brasileira, após as alterações realizadas pelo Marco Legal da Ciência, Tecnologia e Inovação, criou no direito brasileiro um novo regime jurídico para as parcerias público-privadas em pesquisa e desenvolvimento científico e tecnológico, na esteira do reconhecimento de que tais parcerias são fundamentais para o desenvolvimento econômico e social baseado em inovações tecnológicas.

Palavras-chave: Estado Empreendedor. Regulação. Política industrial. Sustentabilidade. Lei de Inovação. Parcerias público-privadas em pesquisa e desenvolvimento. 


\begin{abstract}
This work points out the conceptual underpinnings of the Entrepreneurial State and identifies them in the Brazilian Constitution, in order to draw a theoretical framework for a juridical and critical assessment of industrial policy and science, technology and innovation development. The building blocks of the concept of Entrepreneurial State introduced by Mariana Mazzucato (2014) are deepened and the Brazilian Constitution is explored in order to identify the conceptual elements of this model of State. It is argued that the Brazilian Constitution has adopted the Entrepreneurial State model for the regulation of the science, technology and innovation sector and industrial policy, according to which policy related with these sectors must have state regulation with the objective to promote a sustainable national development. The Entrepreneurial State is conceived as a dimension of the Regulatory State and it has as the main practical consequences the refutation of theories that support the removal of state regulation on markets and the adoption of development policies that value a country's local feature. In this work, it is also supported that the Brazilian Innovation Law, after been reformed by the Brazilian Science, Technology and Innovation Act, created new rules for the public-private partnerships in research and development, recognizing that these partnerships are essential to the social and economic development based on technological innovations.
\end{abstract}

Keywords: The Entrepreneurial State. Regulation. Industrial policy. Sustainability. Brazilian Innovation Law. Public-private partnerships in research and development. 


\section{SUMÁRIO}

INTRODUÇÃO.

\section{CAPÍTULO 1 - ESTADO EMPREENDEDOR E DESENVOLVIMENTO TECNOLÓGICO

1.1. A incerteza no processo de desenvolvimento tecnológico.

1.2. Novas tecnologias, desenvolvimento econômico e criação de mercados.

1.3. Pressupostos conceituais do Estado Empreendedor...........................................................37

1.4. A metalinguagem do Estado Empreendedor.................................................................41

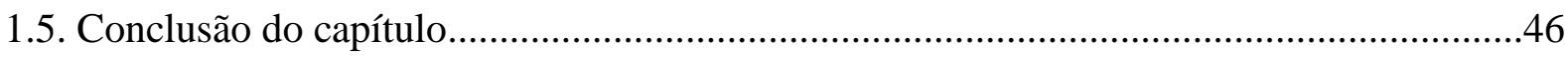

CAPÍTULO 2 - PRESSUPOSTOS CONCEITUAIS DO ESTADO EMPREENDEDOR

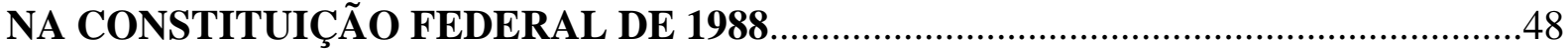

2.1. Estado Empreendedor e capitalismo de Estado...............................................................59

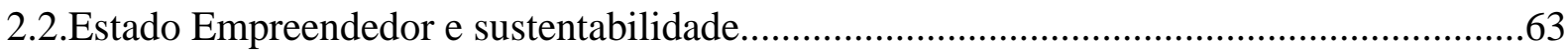

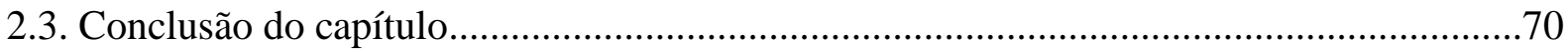

CAPÍTULO 3 - O ECOSSISTEMA DE INOVAÇÃO E O REGIME JURÍDICOADMINISTRATIVO DAS PARCERIAS PÚBLICO-PRIVADAS EM CIÊNCIA, TECNOLOGIA E INOVAÇÃ O...................................................................... 71

3.1. Aspectos gerais do regime jurídico das contratações públicas........................................77

3.2. O regime jurídico-administrativo dos negócios da Administração Pública em ciência, tecnologia e inovação.

3.3. A Lei de Inovação brasileira e o regime jurídico-administrativo das parcerias públicoprivadas em ciência, tecnologia e inovação

3.4. Conclusão do capítulo.

CAPÍTULO 4 - OS CONVÊNIOS DE EDUCAÇÃO, CIÊNCIA, TECNOLOGIA E

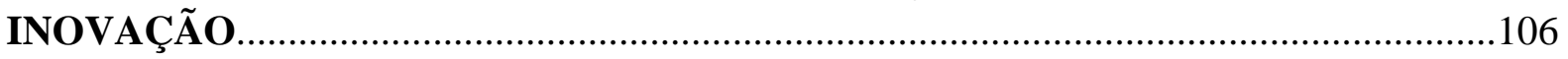

4.1. Convênios de educação, ciência, tecnologia e inovação e fundações de apoio...............109

4.2. Convênios de educação, ciência, tecnologia e inovação e organizações sociais.............113

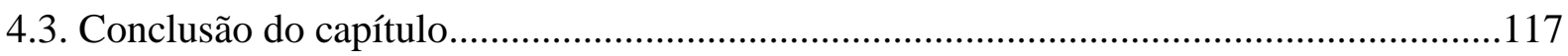

CONCLUSÃO

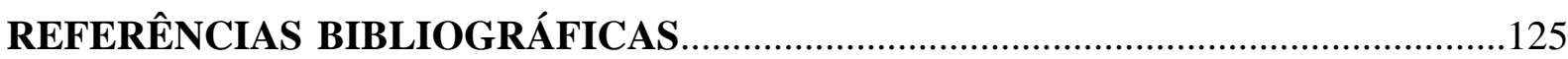




\section{INTRODUÇÃO}

O desenvolvimento econômico é um dos temas mais importantes da agenda política contemporânea nos âmbitos nacional e global. Dele dependem questões que vão desde a qualidade de vida das populações à posição que os países ocupam na geopolítica mundial. Em outras palavras, tanto a vida individual quanto a coletiva em uma nação possuem elementos importantes ligados a questões econômicas, essenciais para a fruição de direitos e o exercício de papéis políticos proeminentes nas relações internacionais.

Atualmente, já se tem experiência histórica suficiente para afirmar que uma economia sólida tem como um de seus pontos de apoio o nível de desenvolvimento tecnológico alcançado pelo país, seja na esfera industrial, com infraestrutura madura dos bens de produção, seja no grau de sofisticação de bens e serviços que põe no mercado. Com efeito, países que hoje figuram na liderança do comércio mundial e têm mantido por décadas seguidas posição de destaque na economia devem esses resultados ao amadurecimento tecnológico de suas indústrias, que ofertam produtos e serviços de elevado nível tecnológico, com alto valor agregado e ampla procura pelos consumidores em todo o mundo. É o caso, por exemplo, dos Estados Unidos, Alemanha e Japão. Mais recentemente, países emergentes que hoje possuem destaque na economia global optaram por seguir a mesma trilha do investimento em tecnologia e inovação em suas indústrias e nos produtos que oferecem, alcançando notável inserção no comércio mundial, exemplos dos quais são Coreia do Sul (CHANG, 1993) e Finlândia (ARBIX e VARON, 2010).

Este é caminho que o Brasil deve seguir se pretende alcançar o mesmo nível dos países mencionados, consolidando uma economia madura e competitiva em nível global, capaz de gerar riqueza de forma sustentável e que dê suporte ao desenvolvimento econômico e social do país. Glauco Arbix (2007) aponta que para o Brasil não existe opção senão inovar, ou seja, desenvolver o nível tecnológico de sua indústria, notadamente pela inovação dos produtos que coloca no mercado, para adquirir maior competitividade no comércio internacional, estando apto a ser exportador de bens com maior valor agregado e que empreguem nível intensivo de conhecimento.

É preciso desenvolver uma cultura de inovação no Brasil, que abranja os diversos atores da economia capazes de produzir inovação: universidades, empresas, pesquisadores, 
centros privados de pesquisa, Estado. A experiência internacional (ARBIX et al, 2010) ${ }^{1}$ demonstra que a instalação de uma ampla rede em prol da inovação promove a elevação do patamar tecnológico do país, refletindo em crescimento econômico sólido por consequência da inserção em mercados de produtos com maior valor agregado no comércio mundial, e também em elevação do nível social do país, pelo esforço que se faz na educação básica e na maior riqueza a ser distribuída. Em outras palavras, o fomento a uma rede ou sistema de inovação traz, com o tempo, resultados positivos concretos em termos de desenvolvimento humano e econômico da nação. A rede de inovação deve ser difusa por todos os setores da economia, a fim de propiciar maior articulação entre os diversos atores e instituições na geração de pesquisas e tecnologias. Portanto, um dos desafios para o desenvolvimento econômico brasileiro é elevar o nível tecnológico de sua indústria e dos produtos que suas empresas comercializam no mercado global. Seguir o caminho da inovação, principalmente através da implantação progressiva e constante de um sistema de inovação abrangente o máximo possível de todas as regiões do país e de diversos setores da economia.

O estabelecimento de uma economia fundada em tecnologia e inovação contribui não só para melhorar o desempenho no comércio internacional, mas também para fortalecer o mercado interno, de modo que os empresários nacionais produzam e forneçam aos consumidores brasileiros produtos que hoje são importados. Os empresários nacionais, por este caminho, retomam espaços do mercado doméstico dominados por empresas estrangeiras, reconquista que aumenta a independência tecnológica do país e amplia a difusão em rede da economia do conhecimento. Uma economia fundada em pesquisa, tecnologia e inovação foi o que faltou ao Brasil no período nacional-desenvolvimentista das décadas de 1960 e $1970^{2}$. Nessa época, houve forte concentração na proteção do mercado nacional e concessão ampla de subsídios a produtores nacionais (modelo de substituição de importações), mas sem ter sido estimulada pelo Estado, nem praticada pelo setor privado, uma cultura de pesquisa e

\footnotetext{
${ }^{1}$ Em 2010, a Agência Brasileira de Desenvolvimento Industrial (ABDI) publicou estudo empírico sobre os sistemas e políticas de inovação em sete países (Estados Unidos, França, Finlândia, Irlanda, Canadá, Reino Unido e Japão), com o fim de observar o que a experiência internacional tinha a oferecer ao Brasil como lições e caminhos ao desenvolvimento através da inovação. Cada país ficou a cargo de um ou mais pesquisadores, que foram in loco averiguar as estratégias e políticas realizadas, entrevistar agentes públicos e demais atores nos respectivos sistemas. O resultado foi um farto conjunto de orientações que poderão ser seguidas e adaptadas às características do Brasil. No estudo, a experiência internacional demonstrou que a inovação pode oferecer um caminho sólido para o desenvolvimento nacional.

${ }^{2}$ Lauro Mattei (2013) afirma que no período do nacional-desenvolvimentismo o modelo de substituições de importações concentrou-se na proteção do mercado interno e na produção voltada para este mesmo mercado, sem buscar uma indústria preocupada com a competição internacional. Segundo o autor, “(...) apesar do impulso dado pelo Estado, as empresas privadas nacionais praticamente tiveram um papel secundário na industrialização do país, fato que levou a desequilíbrios setoriais importantes, particularmente no setor de bens de capital, além de defasagens tecnológicas e baixa competitividade internacional".
} 
inovação, com esforço intensivo em tecnologia, voltada para a competição internacional. O resultado se fez sentir mais claramente a partir da década de 1990, com a abertura da economia brasileira ao mercado internacional, quando o país se viu em dificuldades de competir com outras nações que em décadas anteriores fizeram esforço em matéria de P\&D.

É importante esclarecer que não se desconhece o fato de, especialmente na segunda metade do século 20, ter havido investimentos em ciência e tecnologia no Brasil que levaram à formação da estrutura científica nacional, com surgimento de instituições de pesquisa e constituição de corpo de pesquisadores. Aqui, salientamos que este processo aconteceu com a característica de ter sido capitaneado pelo Estado, em especial através de várias de suas empresas públicas, contudo sem o foco específico na inovação voltada para as exportações, mormente a inovação desenvolvida por empresas privadas brasileiras, nem se buscou o desenvolvimento de relações público-privadas em CT\&I que formassem uma cultura de integração público-privada em inovação na economia nacional. Dessa forma, embora os investimentos públicos tenham formado uma estrutura de pesquisa e desenvolvimento no país e capacitado o Brasil ao acesso de novos setores industriais (petróleo, aviação etc), não houve a formação de uma cultura de inovação voltada para a exportação, principalmente por parte das empresas privadas.

Dados recentes sobre a balança comercial brasileira mostram que, em 2014, nosso principal produto de exportação foi a soja, seguida por minérios, petróleo e combustíveis, material de transporte e carnes. Além disso, no mesmo ano a balança comercial brasileira registrou que apenas $7 \%$ dos produtos exportados pelo Brasil eram de alta tecnologia ${ }^{3}$. Estes dados permitem concluir que o Brasil ainda é um país majoritariamente exportador de produtos primários e importador de tecnologia, o que em termos de balança comercial significa maior desvantagem competitiva em razão do pouco valor agregado dos produtos exportados.

O caminho da tecnologia e inovação requer diversas medidas que passam por uma revolução na educação nacional, o investimento contínuo em infraestrutura e o maciço suporte à pesquisa e desenvolvimento, especialmente para a criação e comercialização de novos produtos e serviços. Certamente, alcançar o patamar de país exportador de tecnologia exige perene investimento em pesquisas que irão gerar novos conhecimentos, a partir dos quais o

\footnotetext{
3 BRASIL. Ministério do Desenvolvimento, Indústria e Comércio Exterior. Balança Comercial Brasileira. Dados Consolidados. 2014. Disponível em: 〈http://www.desenvolvimento.gov.br//arquivos/dwnl_1423144482.pdf〉. Acesso em: 18 mai. 2015.
} 
país produzirá os produtos de alta tecnologia que hoje são importados, além de exportá-los para consumidores estrangeiros, angariando fatias do comércio mundial. É o investimento em pesquisa e desenvolvimento (P\&D) que viabiliza a geração de produtos inovadores (inovação), com abertura de novos mercados e do processo de enriquecimento nacional no âmbito da economia e do conhecimento, ensejando não só desenvolvimento econômico sustentável, mas também social, dado que a elevação do padrão tecnológico constrói o conhecimento que soluciona diversas outras demandas nacionais, não só mercadológicas.

Desde 2000, com a ampliação dos Fundos Setoriais, o Brasil tenta impulsionar sua política de ciência e tecnologia, mediante a consolidação de diretrizes e rumos estratégicos nesse setor e a estruturação de um arcabouço jurídico-institucional em pesquisa e inovação. Além dos citados Fundos , a Lei da Inovação (Lei no 10.973/2004) e a Lei do Bem (Lei no 11.196/2005) são instrumentos jurídicos que vieram somar na estruturação institucional da ciência e tecnologia nacionais. Recentemente, Emenda Constitucional no 85, de 26 de fevereiro de 2015, acrescentou diversos dispositivos à Constituição Federal, alterou outros, e dotou o texto constitucional de conteúdos inéditos que dão embasamento a novas formas de parcerias público-privadas em inovação e à criação de um Sistema Nacional de Ciência, Tecnologia e Inovação, no qual o Estado estimulará a formação e o fortalecimento da inovação nas empresas, bem como nos demais entes, públicos ou privados, a constituição e a manutenção de parques e polos tecnológicos e de demais ambientes promotores da inovação, a atuação dos inventores independentes e a criação, absorção, difusão e transferência de tecnologia.

A agenda da inovação é fundamental para o desenvolvimento econômico e social, através dela os países terão condições de inserção competitiva no comércio internacional e poderão solucionar problemas mediante o emprego de conhecimento e tecnologia. Pesquisas para inovação tecnológica estão na ordem do dia de políticas públicas, sobretudo em países

\footnotetext{
${ }^{4}$ Os fundos existentes atualmente são: Fundo Setorial do Petróleo e Gás Natural (CT-Petro), criado pela Lei no 9.478/97; Fundo Setorial de Energia (CT-Energ), criado pela Lei no 9.991/2000; Fundo Setorial de Transportes Terrestres (CTTranspo), criado pela Lei no 9.992/2000; Fundo Setorial Mineral (CT-Mineral), criado pela Lei no 9.993/2000; Fundo Setorial de Recursos Hídricos (CT-Hidro), criado pela Lei no 9.993/2002; Fundo Setorial Espacial (CT-Espacial), criado pela Lei no 9.994/2000; Fundo Setorial para o Desenvolvimento Tecnológico das Telecomunicações (FUNTELL), criado pela Lei n10.058/2000; Fundo Verde Amarelo (CT-Verde e Amarelo, Universidade-Empresa), criado pela Lei n-10.168/2000); Fundo Setorial de Tecnologia da Informação (CT-Info), criado pela Lei no 10.176/2001; Fundo Setorial de Infraestrutura (CT-Infra), criado pela Lei no 10.197/2001); Fundo Setorial de Saúde (CT-Saúde), criado pela no 10.332/2001); Fundo Setorial Aeronáutico (CT-Aeronáutico), criado pela Lei no 10.332/2001; Fundo Setorial de Agronegócios (CT-Agronegócio), criado pela Lei n- 10.332/2001; Fundo Setorial de Biotecnologia (CT-Biotecnologia), criado pela Lei no $10.332 / 2001$; Fundo Setorial da Amazônia (CT - Amazônia), criado pela Lei no 10.176/2001; Fundo para o Setor de Transporte Aquaviário e Construção Naval (CT- Aquaviário), criado pela Lei no 10.893/2004. Disponível em: < http://www.mct.gov.br/index.php/content/view/724.html?execview=>. Acesso em: 13 jan. 2016.
} 
em desenvolvimento. Nesse cenário, o papel do Estado ganha relevo, notadamente em razão das pesquisas em inovação envolverem capital de risco, tendente a afastar a iniciativa privada que visa retornos certos e rápidos para seus investimentos. As incertezas existentes quanto aos lucros e resultados tecnológicos de investimentos em pesquisas exigem que o Estado se articule para suprir a lacuna do investimento privado. Entra em cena o conceito de Estado Empreendedor (MAZZUCATO, 2014), segundo o qual, cabe ao Estado o papel de conduzir e promover o desenvolvimento tecnológico, especialmente nas fases iniciais das pesquisas cujas incertezas afastam a iniciativa privada. A liderança do Estado nos processos de inovação precisa ser em parceria com o setor privado, cabendo ao parceiro público prospectar nichos carentes de impulso para promoção do desenvolvimento nacional.

A questão que se coloca é: que relação existe entre os elementos conceituais do Estado Empreendedor e a política de ciência, tecnologia e inovação (CT\&I) brasileira pósConstituição Federal de 1988? Trata-se de pergunta fundamental para definição dos papéis que os atores econômicos devem desempenhar na formulação e execução de estratégias e modos de cooperação com o escopo de alavancar o desenvolvimento econômico nacional por meio da tecnologia e da inovação, dado que esta definição necessita de um parâmetro de análise através do qual se possa avaliar as políticas públicas voltadas à CT\&I. Como parâmetro, é apresentado o conceito de Estado Empreendedor, conforme demonstraremos neste trabalho.

Partiremos da premissa de que o desenvolvimento sustentável requer o incremento das políticas de pesquisa e desenvolvimento (P\&D), com acentuação do papel do Estado como financiador e regulador da ciência, tecnologia e inovação nacionais, especialmente para a criação de novos produtos e serviços e respectivos mercados. Para tal escopo, é importante o conceito de Estado Empreendedor que será abordado neste trabalho. Por conseguinte, são necessários o estudo e a fundamentação científica do papel do Estado no desenvolvimento tecnológico e das parcerias público-privadas em P\&D.

Para uma análise jurídica do papel do Estado no desenvolvimento tecnológico, é fundamental se voltar para as normas da Constituição Federal de 1988 que repercutem na política de $\mathrm{P} \& \mathrm{D}$, articulando-as com as regras constitucionais sobre a ordem econômica, com o escopo de identificar elementos que justifiquem o Estado brasileiro como regulador e promotor do desenvolvimento tecnológico. Pretendemos demonstrar que a política de P\&D, tal como estabelecida na Constituição Federal do Brasil, permite a atuação do Estado brasileiro nessa função. 
Demonstrar-se-á a importância das parcerias público-privadas no fomento à pesquisa e desenvolvimento, com foco nas regras que formam o novo regime jurídico dos negócios administrativos em pesquisa e desenvolvimento gerado com as alterações da Lei de Inovação (Lei no 10.973/2004) realizadas pelo Marco Legal da Ciência, Tecnologia e Inovação (Lei no 13.243/2016).

Analisar-se-á também o convênio de educação, ciência, tecnologia e inovação (ECTI), modalidade de convênio que se apresenta como alternativa para estimular parcerias público-privadas em projetos de P\&D. Criado com o Decreto no 8.240 , de 21 de maio de 2014, que regulamenta o art. 1--B da Lei no 8.958, de 20 de dezembro de 1994, o convênio ECTI tem como principal escopo fornecer o arcabouço jurídico para a integração entre centros de pesquisa - notadamente Universidades públicas - e empresas. Esse convênio será analisado face às novas disposições da Lei de Inovação, na tentativa de chegar a conclusões críticas sobre o mesmo, destacando-se, no âmbito desse convênio, a inovação jurídica realizada no regime das organizações sociais que atuam no setor de ciência e tecnologia quanto ao fomento a projetos de pesquisa e desenvolvimento.

Para alcançar esses objetivos, além da análise da Constituição Federal, da Lei de Inovação e do Decreto no 8.240, de 21 de maio de 2014, recorrer-se-á, para melhor compreensão da realidade do Brasil, a pesquisas e dados empíricos produzidos por órgãos ou instituições como a Agência Brasileira de Desenvolvimento Industrial (ABDI), o Instituto Brasileiro de Geografia e Estatística (IBGE) e o Ministério da Indústria, Comércio Exterior e Serviços.

Este trabalho terá quatro capítulos. No primeiro, delimitaremos o papel do Estado no desenvolvimento tecnológico e demonstraremos por que o setor privado, ao contrário do que comumente se imagina, não lidera o processo de inovação tecnológica. Identificaremos os pressupostos conceituais do Estado Empreendedor a partir do papel que o Estado possui em relação ao processo de desenvolvimento tecnológico.

No segundo capítulo, analisaremos as normas constitucionais sobre ciência, tecnologia e inovação com o escopo de demonstrar que a Constituição Federal de 1988 determina a atuação do Estado brasileiro como empreendedor. Serão apontadas as características fundamentais da política de P\&D tal como delineada no texto constitucional, com o fim de embasar a atuação empreendedora do Estado brasileiro em pesquisa e desenvolvimento, sem descurar de outros valores constitucionais importantes como o desenvolvimento nacional sustentável. 
O terceiro capítulo tem por objetivo analisar a importância das parcerias públicoprivadas em $\mathrm{P} \& \mathrm{D}$, por entendermos que o setor privado desempenha papel fundamental neste campo, bem como por serem os agentes privados os realizadores da atividade econômica que produz riqueza. Daremos ênfase à Lei no 10.973, de 2 de dezembro de 2004 (Lei de Inovação), especialmente após as alterações realizadas pela Lei no 13.243 , de 11 de janeiro de 2016, com base na qual sustentaremos ter surgido um novo regime jurídico para as parcerias público-privadas em ciência, tecnologia e inovação.

Por fim, no quarto capítulo nos deteremos na análise dos convênios ECTI, instrumento jurídico de estímulo à integração universidade-empresa, como forma de viabilizar a disseminação de projetos de pesquisa e desenvolvimento no país e contribuir para uma rede de inovação nacional. Para além da mera descrição das características jurídicas desses convênios, pretendemos realizar análise crítica à luz da Lei de Inovação. O fenômeno das relações público-privadas tem se acentuado no mundo contemporâneo, inclusive com transferência de atividades antes desempenhadas pelo Estado ao setor privado, como demonstraremos ter acontecido, no ordenamento jurídico brasileiro, em relação ao fomento à pesquisa e desenvolvimento em parcerias público-privadas envolvendo organizações sociais.

É importante deixar claro que ao mencionarmos "parcerias público-privadas" estaremos usando a expressão em sentido genérico, fazendo referência a qualquer espécie de relação ou negócio jurídico público-privado, sem significar especificamente as parcerias público-privadas previstas na Lei no 11.079 , de 30 de dezembro de 2004, como usualmente são conhecidas no Brasil.

Para os propósitos deste trabalho, convém esclarecer desde já o que se entende por inovação ${ }^{5}$. Na linha do Manual de Oslo (OCDE, 2004), da Organização para Cooperação Econômica e Desenvolvimento (OECD), inovação é a implantação de um produto (aqui abrangendo bem ou serviço) ou processo tecnologicamente novo ou aprimorado. Por implantação se entende a efetiva colocação de um produto no mercado ou a efetiva produção de bens e serviços mediante processo novo ou aprimorado. Produto tecnologicamente novo é aquele que se distingue dos demais existentes por suas características tecnológicas ou pelas aplicações que permite fazer. Estas inovações podem decorrer de novas tecnologias ou da combinação de tecnologias existentes. Foi o caso, por exemplo, quando do surgimento do

\footnotetext{
${ }^{5}$ A Lei no 10.973, de 02 de dezembro de 2004 (Lei de Inovação), após as alterações realizadas pela Lei no 13.243, de 11 de janeiro de 2016, define inovação como "introdução de novidade ou aperfeiçoamento no ambiente produtivo e social que resulte em novos produtos, serviços ou processos ou que compreenda a agregação de novas funcionalidades ou características a produto, serviço ou processo já existente que possa resultar em melhorias e em efetivo ganho de qualidade ou desempenho".
} 
avião, do telefone, do computador, da eletricidade, do automóvel, da televisão. Produto tecnologicamente aprimorado é aquele que, após a incorporação de uma inovação tecnológica, tenha melhoria de desempenho ou de aplicação, ou ainda menor custo, seja pela utilização de novos componentes, ou materiais, ou também pela integração de subsistemas técnicos que lhe confiram tal aprimoramento, dos quais são exemplos o telefone sem fio, o smartphone, o surgimento de computadores com componentes de silício, o surgimento de automóveis com direção hidráulica, de televisores de LED, ou ainda produto com design melhor ou mais belo. Por sua vez, processo tecnologicamente novo ou aprimorado é aquele, assim como nos produtos, em que a inovação gera novo ou aprimorado processo/método de produção (mais eficiente, mais seguro, menos custoso etc.), abrangendo o processo de entrega/distribuição do produto (de forma mais rápida, mais barata, com maior conservação do produto etc.). Neste caso, temos como exemplos o emprego de máquinas no processo de produção industrial, de máquinas colheitadeiras na agricultura, do emprego da tecnologia $4 \mathrm{G}$ para fornecimento de serviços de Internet. Cumpre esclarecer que para a inovação no âmbito de uma empresa ou de um país não é preciso que surja produto ou processo, novo ou aprimorado, inédito no mundo, mas sim na própria empresa ou país. Em outras palavras, se a empresa ou país adquirem o conhecimento para produzir tecnologia já existente, que antes não tinham, terão promovido inovação porque elevaram seu patamar tecnológico, adquirindo a capacidade de ingressar em mercados que antes não acessavam e, em termos de país, obtendo conhecimento que lhe dará independência de fornecedores externos para solução dos seus problemas e acesso a novos mercados.

Cumpre esclarecer, ademais, que o presente trabalho não tratará de questões relativas a direitos de propriedade intelectual. Com efeito, em matéria de inovação tecnológica, temos consciência da importância do regime de direitos de propriedade intelectual, nas legislações nacionais e na internacional. A definição desse regime é essencial porque pode estimular ou tolher empreendimentos em inovação. No âmbito da Organização Mundial do Comércio (OMC), por exemplo, o Acordo Trips (Trade Related Aspects of Intellectual Property Rights) vincula as legislações nacionais dos países signatários a respeitar suas disposições, em geral mais benéficas aos países desenvolvidos e produtores de inovação. O ponto fundamental do regime jurídico da propriedade intelectual é chegar ao meio-termo entre a proteção a quem cria inovações, para que se sinta estimulado a investir, sem a rigidez que impeça a democratização do acesso a novas tecnologias às empresas e países menos desenvolvidos. A crítica que se faz ao Acordo Trips (POLIDO, ROSINA e GUIMARÃES 
CÉSAR, 2012) é por conferir maior proteção aos países já produtores de inovação, o que contribui, em âmbito global, para a manutenção da disparidade tecnológica entre as nações. Nesse contexto, políticas de inovação devem considerar a estrutura jurídica internacional dos direitos de propriedade intelectual para encontrar alternativas inteligentes às suas limitações, criar regimes de propriedade intelectual mais flexíveis, adaptáveis às necessidades de desenvolvimento de cada nação, ou ainda, no âmbito da diplomacia internacional, alterar as regras da OMC para regimes mais democráticos de acesso às inovações. Apesar da importância dessas questões para o desenvolvimento tecnológico e a inovação, elas não serão tratadas aqui dado que sua extensão ultrapassaria os limites deste trabalho, merecendo pesquisa específica complementar a que ora é produzida.

O presente trabalho possui abordagem que vai do geral ao específico, partindo do papel amplo do Estado Empreendedor junto ao desenvolvimento tecnológico, inclusive em seus contornos constitucionais, passando pelas parcerias público-privadas em P\&D regulamentadas na Lei de Inovação até atingir o nível de normas jurídicas concretas pelas quais se formam tais parcerias, a exemplo dos convênios ECTI. Acima de tudo, o trabalho é jurídico, pelo foco nas normas jurídicas que embasam o funcionamento do Estado Empreendedor no desenvolvimento econômico e na regulação da política de P\&D com origem constitucional, pela análise do regime jurídico-administrativo para parcerias públicoprivadas em pesquisa e desenvolvimento, bem como pelos convênios ECTI que encontram fundamento de validade em normas jurídicas. Sobretudo, este trabalho é jurídico porque acreditamos que estamos tratando, no fundo, do desenvolvimento econômico mediante a criação de novos mercados, ponto em que comungamos da ideia de Karl Polaniy (2012), segundo a qual, os mercados são criações do Estado, em outras palavras, criações jurídicas. Entretanto, o trabalho não afasta a abordagem interdisciplinar, especialmente com a economia, de onde tiramos subsídios importantes como se verá ao longo do texto.

Com efeito, cabe ao direito perceber as transformações do mundo para lhes dar a regulação jurídica mais adequada aos objetivos que a nação escolheu para si. Cabe, enfim, ao direito fornecer estruturas que viabilizem as novas relações da ciência, tecnologia e inovação, conferindo-lhes segurança jurídica, controle e transparência, em prol do desenvolvimento nacional sustentável. 


\section{CAPÍtULO 1 - ESTADO EMPREENDEDOR E DESENVOLVIMENTO TECNOLÓGICO}

Aventada na introdução a necessidade de o Brasil investir em pesquisa e inovação tecnológica para se consolidar como país economicamente desenvolvido e se inserir competitivamente no mercado mundial não apenas como exportador de produtos primários, mas, sobretudo, com produtos que empreguem conhecimento intensivo e tenham maior valor agregado, a pergunta que se coloca é a quem cabe o papel de conduzir esse processo no campo da pesquisa, desenvolvimento e inovação? Cabe ao Estado liderar a transição e o amadurecimento tecnológicos da economia, ou se trata de tarefa a ser cumprida pelo setor privado, com o Estado apenas fornecendo os meios e estruturas necessárias?

Segundo Mazzucato (2014), o senso comum imagina que o processo de desenvolvimento tecnológico e da inovação decorre da iniciativa privada, que tomaria a dianteira na concretização de ideias de vanguarda. Ao Estado não caberia este papel, sendo inclusive vinculadas à sua imagem as características de burocrático e ineficiente, incapaz de articular suas estruturas para produzir novos conhecimentos que geram desenvolvimento. $\mathrm{O}$ setor público seria desprovido da capacidade de conduzir processos inovadores, restando a ele apenas dar as condições básicas para que o setor privado possa desempenhar o avanço econômico e tecnológico do país. Estaria incumbido apenas de fornecer educação à população, a infraestrutura básica e as fontes de financiamento e/ou incentivos fiscais para o setor privado atuar na produção de riquezas e condução do processo de desenvolvimento tecnológico.

Contudo, se olharmos para a experiência industrial nos países desenvolvidos e que alcançaram nível de desenvolvimento tecnológico maduro, constataremos que a realidade é bem diferente do discurso veiculado e da imagem que se encontra no senso comum em relação ao papel do Estado no desenvolvimento tecnológico e econômico. A história do desenvolvimento industrial no século 20 oferece exemplos nos quais, por trás de grandes avanços tecnológicos que geraram produtos inovadores e abriram amplos mercados, ou ainda de tecnologias cuja aplicação se difunde por toda a economia, alterando a forma de produção e distribuição dos bens e a relação entre os agentes da economia (tecnologias de propósito geral, como a Internet), houve a atuação estatal, que os tornou possível e sem a qual não teriam sido gerados. Diversas inovações tecnológicas surgidas nos países desenvolvidos 
demonstram um papel proeminente por parte do Estado na condução das pesquisas e no aporte de investimentos necessários ao seu surgimento, não por parte do setor privado. Mariana Mazzucato (2014) oferece inúmeros exemplos de liderança do Estado no financiamento e condução das pesquisas que resultaram em novas tecnologias que criaram novos mercados e impulsionaram o desenvolvimento econômico em vários setores, desde medicamentos a tecnologias que tornarem possível o smartphone. A Internet, por exemplo, uma tecnologia de propósito geral, cuja aplicação é fundamental para a economia contemporânea, foi desenvolvida pela Agência de Projetos e Pesquisa Avançada de Defesa (Darpa) dos Estados Unidos, durante a Guerra Fria, quando existia no mundo o medo de guerra nuclear, o que levou os militares americanos a desenvolverem uma rede que pudesse manter a comunicação entre as unidades militares em caso de ataque nuclear. Posteriormente, esta rede foi aplicada para fins civis e com sua difusão chegou-se à atual Internet, ligando pessoas no mundo todo e afetando as mais diversas áreas da vida humana, inclusive a economia. Assim como a Internet, a tecnologia do GPS (Sistema de Posicionamento Global ou, em inglês, Global Positioning System) também foi desenvolvida pela pesquisa militar norte-americana através do Departamento de Defesa dos Estados Unidos, inicialmente para fins militares, mas depois difundida para uso civil e comercial.

No âmbito da indústria de medicamentos, os exemplos são inúmeros. Em regra, novas unidades moleculares (novas drogas) são desenvolvidas mediante financiamento público, em razão do longo tempo de pesquisas (mais de dez anos em média) e do volume de investimentos necessários para obtenção do conhecimento que produz novos medicamentos. O longo tempo de pesquisas e o volume de recursos necessários desestimulam os investimentos privados em razão do interesse pelo lucro no curto prazo que move o setor privado. Além disso, há a incerteza de retorno das pesquisas que podem não gerar conhecimento científico ou ainda qualquer produto comercializável. Somente o Estado, movido por objetivos outros que não o lucro, é capaz de liderar pesquisas cujo tempo e recursos necessários desestimulariam a iniciativa privada. O Orphan Drug Act (Lei dos Medicamentos Órfãos), nos Estados Unidos, é um exemplo de como a liderança do Estado no âmbito da indústria de medicamentos é fundamental para o surgimento de inovações que produzem novas unidades moleculares. Essa lei tem por objetivo estimular as pesquisas de remédios para tratamentos de doenças raras, aquelas que atingem em média até duzentos mil habitantes. Como a população afetada por essas doenças é estatisticamente pequena, laboratórios privados não se viam motivados a investir longo tempo e grande volume de 
recursos em pesquisas visando desenvolver medicamentos cujo mercado consumidor é potencialmente pequeno. Tal investimento não compensaria pela perspectiva da iniciativa privada, que foca o lucro no curto prazo. Com o Orphan Drug Act o Estado pode financiar pesquisas para produção de medicamentos contra doenças raras e atender à população afetada (MAZZUCATO, 2014). Com o suporte estatal, desenvolveu-se a tecnologia que criou um novo nicho no mercado de medicamentos, estimulando a produção de novas drogas para serem comercializadas pelas próprias empresas que se negaram a investir nas pesquisas necessárias. Inúmeros outros casos de medicamentos são desenvolvidos em laboratórios públicos ou com financiamento público, o que demonstra o papel fundamental do Estado como agente condutor do processo de inovação.

Em outros países que, a exemplo dos Estados Unidos, desenvolveram suas economias pela inovação tecnológica de seus produtos, a presença do Estado foi fundamental para criar o ciclo de desenvolvimento, assumindo a coordenação e o papel proeminente de investimentos em pesquisa. Japão e Alemanha são exemplos deste processo. Mais recentemente, a Finlândia (ARBIX e VARON, 2010) se apresenta como outro caso concreto de país que saiu de uma economia preponderantemente baseada em recursos naturais para uma nova economia sustentada pela inovação, mediante processo de transformação conduzido pelo Estado. Em cerca de 20 anos, especialmente a partir de 1990, a Finlândia conseguiu a mutação de sua economia lastreada em produtos primários como papel, celulose, madeira, têxtil e calçados para figurar com destaque no comércio internacional, com exportações de eletrônicos e eletroeletrônicos, adquirindo grande competitividade no mercado global. Essa transformação se deu pelo decisivo papel regulatório do Estado, que conseguiu formar consenso político para investir em educação e ciência, tecnologia e inovação, com elevação progressiva dos investimentos públicos nestes setores até conseguir atingir em 2007 o correspondente a $3,7 \%$ do PIB, com planos de aumento para os anos seguintes. Os investimentos em educação, da básica à universitária, e no setor de $\mathrm{P} \& \mathrm{D}$, deram o ambiente material e humano necessários para o surgimento dos primeiros resultados positivos. $\mathrm{O}$ mercado de trabalho se fez sentir com mais profissionais qualificados para sustentar a transformação da economia rumo à oferta de produtos com emprego intensivo de conhecimento. As políticas voltadas à P\&D passaram pela criação de um Sistema Nacional de Inovação, que articulou órgãos e agências públicos, setor privado (empresas) e centros privados e públicos de pesquisa (universidades). O papel do Estado consistiu em disponibilizar amplas fontes de financiamento, dentre elas fontes não reembolsáveis, com 
assunção do risco dos investimentos em projetos que se mostrariam desestimulantes para o setor privado. Fomentaram-se interações público-privadas (universidade-empresa em especial), com políticas e programas públicos para estimular sinergia entre os diversos atores do sistema nacional de inovação, a fim de criar uma estrutura de produção baseada no uso intensivo do conhecimento. Outra estratégia adotada pelo Estado foi ampliar a internacionalização dos atores da economia finlandesa, através da adoção de padrões internacionais de seleção de projetos a serem financiados, especialmente pelo seu potencial de competitividade, a atração de pesquisadores estrangeiros ao país e a abertura de centros de pesquisa finlandeses no exterior, com o objetivo de aquisição de novos conhecimentos. A experiência finlandesa demonstra que o Estado desempenhou papel essencial no processo de desenvolvimento tecnológico do país, porque cabe a ele - além de investimentos essenciais em projetos cuja incerteza afasta o setor privado - fazer políticas públicas que estimulem os diversos atores da economia, a sinergia entre estes, determinar os rumos da transição econômica e manter constante a estratégia de desenvolvimento pela inovação, com aplicação de recursos públicos em áreas que promovam o crescimento do conhecimento. O setor privado também tem papel essencial no processo de crescimento pela inovação e no caso finlandês não foi diferente. A Nokia é o principal símbolo da transição da economia da Finlândia para a inovação e de sua competitividade internacional. O Estado finlandês financiou esta empresa e as pesquisas que geraram muitos dos seus produtos, além de a empresa ter se beneficiado da elevação da qualificação do mercado de trabalho nacional como consequência dos investimentos públicos em educação e P\&D, mas também seu sucesso se deve à sua postura de busca pela inovação e por seus investimentos em pesquisa e desenvolvimento. De fato, para que haja a transição para a economia da inovação, setores públicos e privados devem estar dispostos a empreender esforços neste sentido e a atuarem em conjunto (parcerias), cada qual no seu papel, para atingirem a elevação do patamar tecnológico do país.

Dentre todos os países que alcançaram recente e notável desenvolvimento pelo caminho da inovação tecnológica, a Coreia do Sul é um dos exemplos mais marcantes do papel proeminente do Estado na condução do processo de desenvolvimento. Desde o início da década de 1960, o Estado sul-coreano adotou uma postura intervencionista e desenvolvimentista, concentrando seus esforços de política industrial no objetivo da criação no país de atividades em setores da economia que dependiam do mercado externo. Ha-Joon Chang (1993) demonstra que a Coreia do Sul definiu setores prioritários a serem criados em 
sua economia, inicialmente indústrias básicas como cimento, fertilizantes e refino de óleo. Em seguida, após o estabelecimento destas indústrias básicas iniciais, passou-se a um segundo momento de formação de indústrias no país, tendo como atividades prioritárias as relacionadas ao aço e maquinaria. Nas terceira e quarta fases, os esforços se concentraram em metais não ferrosos, construção naval e eletrônicos, sendo mantidos os esforços da política industrial, no quinto e sexto períodos, em maquinaria, eletrônicos, automóveis, indústria química, naval e várias outras com emprego intensivo de alta tecnologia (semicondutores, novos materiais, biotecnologia). Progressivamente, ao longo de três décadas, o Estado sulcoreano foi formando diversas indústrias no país, inovando em produtos e processos e fazendo com que sua própria economia produzisse o que antes adquiria no mercado externo. Isso foi possível porque o Estado intervencionista realizou políticas econômicas e industriais que, num primeiro momento, atacaram dois problemas considerados impeditivos ao desenvolvimento nacional: a falta de poupança interna para alavancar investimentos e a pequena capacidade tecnológica do país. O Estado chegou a realizar política de desincentivo ao consumo para fomentar a poupança necessária aos investimentos. A economia foi aberta ao mercado externo, mas como substanciais restrições tarifárias com o fim de proteger os empreendedores locais em processo de formação de suas indústrias. Com este objetivo, de um lado o governo controlou severamente produtos importados, negando crédito a importadores, ao mesmo tempo em que, do outro lado, concedia créditos a empresários locais que chegavam a $90 \%$ do valor dos produtos, máquinas em especial, com o fim de impulsionar a indústria local. Baixas taxas de juros eram concedidas aos empresários locais que formavam novas atividades industriais. O objetivo era aumentar a independência da Coreia do Sul, princípio conhecido como "melhoramento" (upgrading) da estrutura industrial nacional. Um conjunto de medidas integradas compunha a política industrial sul-coreana, com destaque para o monitoramento mensal de desempenho das empresas que recebiam suporte do Estado e programas de racionalização que limitavam temporalmente o apoio financeiro com o fim de estabelecer metas de resultados, demonstrando a capacidade do Estado em retirar investimentos quando a empresa fomentada não apresentava os retornos esperados. Em sua relação com o exterior, a política industrial sul-coreana buscou a assimilação por empresas locais de tecnologias mais avançadas desenvolvidas em outros países. Institucionalmente, foram implementadas inovações que permitiram melhorar a articulação do Estado no processo de desenvolvimento industrial, em especial pela concentração de decisões políticas e econômicas num mesmo órgão, evitando conflitos internos que poderiam prejudicar seu funcionamento. A experiência sul-coreana demonstra ser fundamental a atuação regulatória 
do Estado no processo de formação de novas atividades e novos mercados, mediante processo de inovação tecnológica que confere independência ao país face ao mercado externo e maior competitividade no comércio mundial. O papel do Estado foi fundamental porque, embora a riqueza fosse gerada pelas empresas, foi o Estado quem garantiu uma série de condições para a formação destas empresas e seu desenvolvimento, como medidas jurídicas que protegeram o mercado interno de concorrentes externos, bem como políticas regulatórias e de fomento que disciplinaram empresas e as pessoas em geral. No processo de desenvolvimento sul-coreano, a presença do Estado foi tão marcante e decisiva que, segundo Ha-Joon Chang (1993), valiase de práticas como fusões obrigatórias de empresas e retiradas compulsórias de empresas de determinados setores para abrir espaço ao surgimento de novas, medidas impensáveis no mundo ocidental democrático. Em suma, o processo de desenvolvimento industrial da Coreia do Sul confirma que foi o Estado quem conduziu a formação de novos mercados no país por meio da inovação de produtos e processos que alavancam a autonomia tecnológica nacional. As políticas públicas necessárias são formadas por um complexo de estratégias que se somam num processo de longo prazo, no qual erros são cometidos, mas o aprendizado adquirido corrige rumos e contribui para o aperfeiçoamento institucional.

A experiência brasileira também oferece exemplos de como o Estado está por trás do processo de inovação em setores fundamentais da economia, abrindo novas possibilidades de produtos que ampliam horizontes mercadológicos. Nosso principal setor de exportações, a agropecuária, deve grande parte de seu sucesso às pesquisas desenvolvidas com financiamento público pela Embrapa, a Empresa Brasileira de Pesquisa Agropecuária (BUAINAIN et al, 2014). Foi principalmente devido à pesquisa agropecuária e às inovações geradas neste setor que o Brasil deixou de ser o importador de gêneros alimentícios que era na década de 1960 para atualmente ser exportador e disputar com os Estados Unidos a liderança mundial no comércio de commodities agropecuárias. Em 1975, a produção agropecuária brasileira era de 45 milhões de toneladas, e chegou em 2013 a 187 milhões, de modo que hoje o Brasil domina 34\% do comércio mundial. A intensa produção agrícola brasileira tem reflexo positivo na balança comercial. Os ganhos intensivos em produtividade e o aumento do volume das exportações fizeram a balança comercial do setor agropecuário passar do saldo positivo de 7 bilhões de dólares em 1990 para 83 bilhões em 2013, suprindo deficits de outros setores da economia que não conseguem repetir o mesmo sucesso exportador da agropecuária. O crescimento das exportações brasileiras no setor teve seu início a partir da década de 1980, quando as taxas de produtividade brasileira passaram a ser superiores às do restante do 
mundo, crescimento sustentado no tripé crédito rural, extensão técnica produtiva e pesquisa agropecuária. O salto de qualidade na agropecuária brasileira se deu com a implantação de um sistema nacional de pesquisas agropecuárias, capitaneado pela Embrapa, criada em 1973, e composto também por instituições estaduais, universidades e instituições privadas. Este sistema foi se ampliando e ganhando complexidade ao longo dos anos e tem como característica a interação entre as instituições e órgãos componentes, especialmente entre instituições públicas e privadas, aqui inseridas as empresas. A adoção da pesquisa de inovações para sustentação do desenvolvimento agropecuário no Brasil mostrou-se um caminho de sucesso e corrobora a tese de que a economia do conhecimento é a chave para o desenvolvimento econômico sustentável. O Brasil fez-se inserir na moderna agricultura e agora colhe os resultados positivos na economia: grande volume de exportações, competitividade internacional, acesso a ampla fatia do mercado mundial, balança comercial positiva no setor, geração de riqueza e empregos no país. A modernidade da agropecuária brasileira se fez com inovações químicas, mecânicas e de biotecnologia. Esta última, por exemplo, tem efeitos diretos em simplificação do manejo de culturas, redução de custos e ganhos de produtividade. O Estado teve papel decisivo neste processo, seja por tomar a decisão política de mudar o quadro agropecuário nacional, seja por criar os meios necessários para a mudança, disponibilizando financiamentos, fomentando pesquisas, promovendo interações entre os diversos atores do setor e construindo as estruturas indispensáveis. Sem a assunção de riscos e investimentos por parte do Estado brasileiro, notadamente por meio da Embrapa, muitas inovações não teriam surgido. A implantação de um novo produto no mercado, especialmente em biotecnologia, pode requerer, no mínimo, uma década de pesquisas e investimentos. Tome-se o exemplo da soja, que atualmente ocupa o primeiro lugar dentre todas as exportações brasileiras. O governo federal custeou pesquisas de biotecnologia na Embrapa que viabilizassem seu cultivo no Centro-Oeste brasileiro, a fim de expandir a fronteira agrícola do país, dado que esta cultura não se mostrava adaptável às características do ecossistema do cerrado. Com o sucesso das pesquisas, o governo financiou agricultores regionais para testarem o plantio da soja na região e, numa fase seguinte, concedeu financiamentos para consolidar o plantio no Centro-Oeste. O sucesso das pesquisas e dos incentivos financeiros governamentais levou a expansão agrícola brasileira para o centro do país, que atualmente é um dos celeiros do mundo. Além das inovações biotecnológicas na soja nacional, diversas outras ajudaram a transformar a agropecuária brasileira numa das mais avançadas do mundo: inovações genéticas, novos defensivos agrícolas, fertilizantes, sementes mais resistentes e adaptadas aos ecossistemas nacionais. O Brasil se tornou produtor de 
conhecimento de produção agropecuária em regiões tropicais. Estima-se que a tecnologia seja responsável, em termos percentuais, por $68 \%$ do processo produtivo agrícola do país. O surgimento de inovações na agropecuária gerou também um ciclo positivo em outros setores. Com a indústria, por exemplo, a demanda agropecuária decorrente de sua expansão promoveu interações benéficas, com maior produção, inclusive com inovações, de bens como tratores, caminhões, máquinas e implementos agrícolas. Os efeitos positivos se fizerem sentir em outras áreas importantes da sociedade. De 1974 a 2006, por exemplo, a oferta mais abundante de alimentos como consequência da maior produtividade promoveu a queda constante dos preços, contribuindo para o controle inflacionário da moeda e para a diminuição da pobreza e da fome no país em razão do maior acesso a alimentos, elevando o patamar nacional em termos de segurança alimentar. $\mathrm{O}$ sucesso da agropecuária brasileira nas últimas três décadas comprova que o investimento em pesquisa e inovação, num processo liderado pelo Estado, constrói o desenvolvimento econômico e social sustentável, abre novos mercados, insere o país na economia mundial, aumenta sua competitividade e confere independência à nação em questões estratégicas, devendo ser uma política reproduzida nos demais setores da economia.

A Petrobras talvez seja o maior exemplo brasileiro de inovação, pesquisa e desenvolvimento criado a partir da iniciativa do Estado. Trata-se de empresa por meio da qual o Estado brasileiro possibilitou ao país sua inserção no mercado petrolífero mundial, sendo atualmente uma das gigantes globais no setor. Criada em 1953, por meio da Petrobras o Estado brasileiro desenvolveu ao longo do tempo as condições para a exploração de petróleo e gás natural, estendendo sua atuação em diversas áreas que abrangem exploração e produção de petróleo e gás natural, refino, petroquímica e fertilizantes, geração de energia elétrica, produção de biocombustíveis, transporte e comercialização. Neste processo, pesquisa e inovação foram as chaves do desenvolvimento da empresa e do mercado por ela gerado ao país. A empresa investe em $P \& D$ e tem na inovação de produtos e processos o diferencial que lhe garante inserção e conquista de mercados. O Centro de Pesquisas e Desenvolvimento Leopoldo Américo Miguez de Mello (Cenpes), localizado no Rio de Janeiro, é atualmente um dos principais complexos de pesquisa e inovação no mundo, amplamente dotado da capacidade de produzir conhecimentos que geram novos produtos e processos de produção capazes de aumentar a presença da empresa, e do país, no mercado prolífero e de seus derivados no mundo. Foi a adoção do caminho da pesquisa, desenvolvimento e inovação que permitiu a descoberta de imensa quantidade de petróleo na camada de pré-sal do litoral brasileiro, descoberta petrolífera considerada uma das mais importantes do mundo nos 
últimos anos, que oferecerá a matéria-prima necessária para aumentar a produção brasileira para o mercado interno e para as exportações durante décadas, mantendo o país inserido e com destaque no mercado mundial do setor. A exploração de petróleo na camada pré-sal, considerada de ultraprofundidade, exigiu amplo esforço de inovação para desenvolvimento de novas formas de perfuração e extração do petróleo (inovação de processos), o que foi realizado com tecnologia própria da Petrobras. A empresa é um notável exemplo de como a iniciativa do Estado pode criar novos mercados para o país e realizar um ciclo produtivo positivo, com geração de riqueza, postos de trabalho e aumento das exportações. As atividades da Petrobras se articulam com a indústria nacional, da qual demanda bens e serviços para o fomento do crescimento econômico local em diversos setores.

Uma diferença importante entre Embrapa e Petrobras, que deve ser evidenciada, está no fato de que a primeira não realiza atividade econômica, ao contrário da Petrobras, que explora as diversas cadeias de produção e comercialização de petróleo e gás natural. Em termos de ciência, tecnologia e inovação, a Embrapa realiza pesquisa para que seus resultados tecnológicos sejam aplicados por empresas que exploram a atividade econômica, visando ao desenvolvimento econômico e social da agropecuária brasileira. A Petrobras, por sua vez, realiza pesquisas para aplicar em seus próprios produtos. Aqui o Estado é explorador da atividade econômica e, para melhor realizar esta empresa, investe em pesquisa tecnológica e inovação. Através da Embrapa, o Estado não explora atividade econômica, mas investe em tecnologia e inovação para desenvolver a economia nacional, fortalecendo as empresas nacionais pela inovação. Veremos mais à frente que o Estado Empreendedor está mais afinado ao papel da Embrapa, eis que segundo o ordenamento constitucional brasileiro apenas excepcionalmente o Estado explorará atividade econômica. O Estado Empreendedor é regulador e incentivador da ciência e tecnologia, não estatizante da produção econômica.

A Embraer é outro exemplo brasileiro de empresa bem-sucedida, criada pelo Estado, que trilha o caminho da pesquisa e inovação tecnológica e teve como resultado a criação de novo mercado para o país de forma competitiva em nível global. Foi criada em 1969, vinculada, à época, ao Ministério da Aeronáutica, e teve como objetivo principal o desenvolvimento da indústria aeronáutica no país. Atualmente, privatizada, é uma das quatro maiores empresas do mercado de aeronaves no mundo, produzindo aviões para uso comercial, executivo, defesa e segurança e para a aviação agrícola. Pesquisa e desenvolvimento são as bases para a atuação da empresa desde sua fundação, por meio da qual tem ao longo de sua história inserido novos aviões no mercado e conquistado competitividade no comércio 
mundial. No caso da Embraer, a iniciativa estatal resultou na inserção do Brasil no mercado internacional de aeronaves, posição alcançada graças ao investimento em pesquisa e inovação.

Outras empresas foram criadas no Brasil por iniciativa do Estado e inseriram o país no mercado global em seus respectivos segmentos. Neste processo é possível citar a então Companhia Vale do Rio Doce, criada em 1942 para atuar no setor de mineração, atualmente privatizada e considerada uma das maiores no mundo. A Companhia Siderúrgica Nacional, criada em 1941 como empresa estatal, inseriu o Brasil no mercado de produção e exportação de aço, abastecendo a indústria nacional com matéria-prima para setores como o automobilístico, construção civil, eletrodomésticos, dentre outros, além contribuir para o aumento das exportações brasileiras. Na história industrial brasileira, a atuação do Estado teve peso decisivo para formar mercados e inserir a participação do país na competitividade global em setores hoje fundamentais para as exportações e que colocam o país como um dos mais ricos do mundo. A iniciativa do Estado através de suas empresas fomentou o desenvolvimento tecnológico e industrial nacional em áreas onde a participação brasileira era inexistente, criando a base tecnológica necessária para explorar as potencialidades econômicas do país, gerar riqueza, formar o mercado de trabalho qualificado e inserir o país na economia global. Mariana Pargendler (2013) demonstra que especialmente na segunda metade do século 20 cresceu significativamente a atuação do Estado na economia através da criação de empresas estatais. A grande maioria destas empresas foi formada a partir da poupança decorrente de impostos (PARGENDLER, 2013). A autora aponta que de 1966 a 1976 foram criadas por volta de 231 empresas públicas. Estas empresas contribuíram para o desenvolvimento tecnológico e industrial do país e trilharam o caminho da inovação, tendo em vista que não poderiam ingressar no comércio mundial sem a oferta de produtos com competitividade e processos de produção capazes de atender à demanda externa nos padrões internacionais.

Os exemplos acima, de países que trilharam o caminho do desenvolvimento tecnológico, e do próprio Brasil, demonstram o papel do Estado como condutor do desenvolvimento econômico através da pesquisa e inovação. É o Estado quem, em regra, toma a iniciativa de desbravar setores tecnológicos novos, abrindo fronteiras mercadológicas através da inovação, ao tempo em que insere o país num novo patamar econômico como consequência de seu ingresso competitivo em novos mercados.

Dani Rodrick (2004) ressalta que quanto mais um país se desenvolve maior o grau de diversificação de sua economia. Em outras palavras, países desenvolvidos não se concentram em apenas um setor econômico, mas ampliam o leque de produtos e serviços que 
suas economias realizam. Assim, políticas industriais devem focar a criação de novas atividades econômicas, em diversos setores da economia. O modelo de política industrial (política de reestruturação econômica) a ser buscado é aquele que tenha uma colaboração estratégica entre o setor privado e o governo, com o objetivo de descobrir os obstáculos mais significativos à restruturação econômica e que tipo de intervenção é mais adequada para removê-los. Através do processo que Rodrick denomina de "autodescoberta" (self discovery), o país poderá desenvolver a capacidade de produzir internamente, e com menores custos, tecnologias e produtos antes adquiridos do exterior. Isso é possível através de políticas que subsidiem investimentos em novas indústrias, não em indústrias já estabelecidas. Raramente uma reestruturação industrial se dá sem significativa assistência governamental. Além disso, para uma política industrial de sucesso é fundamental que exista organização institucional adequada. Esta será aquela que permita o fluxo de informações entre os setores público e privado, a fim de que se tenha conhecimento dos principais obstáculos ao desenvolvimento empresarial. Para tanto, é preciso encontrar um ponto intermediário entre o completo isolamento dos formuladores de políticas em relação ao setor privado e uma relação excessivamente próxima que acabe por permitir a captura do funcionamento público por interesses privados. O modelo hierárquico de relação entre Estado e setor privado, principalmente em ambientes de alta volatilidade e incerteza, mostra-se inadequado. É preciso, portanto, uma forma mais flexível de colaboração estratégica entre os setores público e privado, desenhado para permitir a troca de informações, a distribuição de responsabilidades e a avaliação dos resultados alcançados. A política industrial deve focar áreas que podem fazer a diferença no desenvolvimento econômico, observando criticamente as características das circunstâncias locais, não apenas um aspecto genérico de programas de incentivo que se receitam para todos os países em qualquer situação. Contudo, embora as políticas industriais devam ter um direcionamento para as especificidades de cada localidade/região, Rodrick aponta algumas medidas concretas que podem ser prescritas para a política industrial do século 21, tais como (1) financiar os custos da "autodescoberta", especialmente em áreas onde a incerteza afasta a iniciativa privada, mediante regulação que estimule a competição das empresas pelo custeio público submetido a condições tais como (a) que as pesquisas visem gerar novas atividades industriais, (b) que tenham o potencial de gerar novos conhecimentos para outros setores da economia e (c) que as entidades do setor privado aceitem se submeter à supervisão pública e a auditorias de performance; (2) desenvolver mecanismos de financiamento de alto risco, dado que mesmo quando é superada a fase de investimentos iniciais na pesquisa básica, a continuidade da pesquisa aplicada exige investimentos de longo 
prazo e risco, sendo necessário criar formas adequadas de financiamento para realização das pesquisas, cujas alternativas possíveis são os bancos de desenvolvimento, fundos públicos, garantias públicas para empréstimos bancários de longo prazo, dentre outras; (3) criar políticas direcionadas para as deficiências de cada setor, especialmente mediante oitiva e interlocução com o setor privado, em âmbito nacional, regional e local; (4) pesquisa e desenvolvimento públicos, voltados para atendimento das demandas do setor empresarial e industrial; (5) financiar treinamento de pessoal focando nas demandas do setor privado; (6) repatriar cientistas e pesquisadores que estão no exterior, mediante incentivos e condições vantajosas para que usem seus conhecimentos no processo de "autodescoberta" nacional. Muito mais que atrair investimentos externos e privilegiar apenas empresas exportadoras, o foco principal segundo Dani Rodrick (2004) deve ser a criação de competências e tecnologias internas que abram novas possibilidades de atividades econômicas ao país.

\section{1 - A incerteza no processo de desenvolvimento tecnológico}

A atuação protagonista do Estado no desenvolvimento tecnológico não decorre apenas do seu papel de incentivador do crescimento nacional (Estado desenvolvimentista), mas também, e principalmente, em razão de um componente inerente ao processo de inovação que se mostra decisivo para, em regra, afastar a iniciativa privada e exigir do Estado o empreendedorismo na geração de novas tecnologias.

Uma das características mais marcantes no campo do desenvolvimento tecnológico, responsável por desestimular os investimentos do setor privado na fase inicial das pesquisas, é a incerteza quanto à obtenção de resultados, tanto em termos da produção de novo conhecimento (resultados científicos) quanto da aplicação destes conhecimentos em produtos e processos de produção (resultados mercadológicos). Deve-se a Frank Night (1972) a demonstração da importância do fator incerteza para a economia e sua diferença substancial em relação ao risco, dois elementos fundamentais da atividade econômica que repercutem diretamente no processo de desenvolvimento tecnológico. Na atividade econômica, a reunião de fatores de produção para a realização da empresa pressupõe a previsão dos possíveis cenários a serem enfrentados e das dificuldades a serem superadas para que o empreendimento obtenha sucesso. $\mathrm{O}$ empreendedor, ao tomar decisões empresariais as mais diversas, tentará ao máximo evitar o erro ao eleger as opções possíveis. A possibilidade maior 
ou menor de previsão dos cenários futuros vai depender dos diferentes tipos de situação de probabilidade, distintas entre si conforme o grau de probabilidade envolvida. No risco, embora as variáveis não sejam controláveis e não seja possível enumerar a priori as alternativas prováveis e suas combinações, ainda se pode recorrer a uma classificação empírica de casos passados que forneçam uma probabilidade estatística. Há risco, por exemplo, ao se abrir uma empresa: pode-se conhecer o produto a ser vendido ou produzido, a característica do mercado local, os consumidores e suas preferências, os concorrentes e seus produtos, as despesas necessárias e todos os demais elementos que direta ou indiretamente vão influenciar na empresa, sendo possível fazer minimante cálculos e prognósticos, inclusive se basear em dados estatísticos de empresas anteriores no mercado local. Há sempre a possibilidade de o negócio fracassar, mas as variáveis são relativamente conhecidas com base em experiências passadas, embora não controláveis ao todo, não sendo possível fazer uma probabilidade plenamente segura sobre as variáveis envolvidas.

A incerteza apresenta grau maior de probabilidade envolvida em comparação ao risco. Segundo Knight (1972), na incerteza "não há base válida de qualquer espécie para classificar-se os casos" [sic]. Em outras palavras, significa a completa ausência de conhecimento sobre as variáveis presentes em determinada atividade ou projeto, o que impede o cálculo das possibilidades para fazer qualquer espécie de prognóstico. A "incerteza knightiana" situa-se no campo do pleno desconhecimento das variáveis envolvidas no empreendimento, de modo a não permitir sequer comparação com situações passadas, ou tentativa de esboçar prognósticos a partir de dados estatísticos que apontem caminhos de sucesso. A título de exemplificação de situação de incerteza, tome-se o empreendimento marítimo dos portugueses na época das grandes navegações (século 15), quando se lançaram ao mar em busca de novas terras sem terem ideia do que poderia acontecer. Não sabiam se encontrariam terra, se aportariam em algum lugar, o que encontrariam, se a comida seria suficiente para a jornada, nem se a eventual terra a ser encontrada teria algum valor, muito menos se voltariam com vida da aventura. Não havia uma base empírica anterior que pudesse fornecer parâmetros que ao menos permitissem prognósticos, ainda que parciais, sobre as variáveis envolvidas no empreendimento. Tome-se ainda o exemplo das pesquisas para o desenvolvimento de uma vacina inédita contra a dengue, realizadas no Brasil pelo Instituto Butantan e pela Fundação Oswaldo Cruz, empreendimento que, quando do seu início, não tinha qualquer indício de sucesso, apenas a certeza do desafio de criar uma nova fronteira na medicina no combate a uma das doenças que mais assolam o país. É a incerteza, no sentido 
explicado por Frank Knight, que existe no campo do desenvolvimento tecnológico. Quando do início de um projeto cujo objeto é a criação de nova tecnologia, inovação de produto ou processo, criação de novos medicamentos, ou nova tecnologia de propósito geral, não se sabe se as pesquisas iniciadas poderão gerar algum conhecimento básico e se este poderá ser aplicado em algum produto comercializável. Há pleno desconhecimento quanto ao sucesso científico e mercadológico do projeto. É possível que a pesquisa dure vários anos, consuma grande volume de recursos, e, ao final, nenhum resultado positivo seja produzido.

O setor privado, diante da incerteza que marca o processo de inovação tecnológica, desestimula-se em fazer investimentos e dar a largada em pesquisas para aquisição de novos conhecimentos. Isso porque o lucro no curto prazo é o principal fator que move os investimentos privados. Nenhum investidor privado irá, em regra, aportar capital em projeto que não tenha prazo nem certeza mínimos de retorno. Pesquisas para desenvolvimento de novas tecnologias levam em geral mais de dez anos para obterem resultados concretos. $\mathrm{O}$ capital privado, por sua vez, geralmente espera retornos no período de três a cinco anos, em média, segundo Mazzucato (2014). Neste cenário, observa-se que somente quando as pesquisas superam a fase inicial e algum conhecimento básico é obtido, passando-se de um cenário de incerteza para de risco, é que as empresas privadas começam a ingressar na cadeia de pesquisa, visando transformar a pesquisa básica em aplicações que gerem novos produtos comercializáveis. O capital privado não gosta de operar em cenários de risco, menos ainda no âmbito da incerteza, e geralmente ingressa ou inicia projetos de pesquisa e inovação quanto já há uma base científica construída que minora as possibilidades de insucesso dos investimentos. É na fase da incerteza que o papel do Estado se mostra fundamental para iniciar o processo de desenvolvimento tecnológico, através de laboratórios ou financiamentos públicos. Isso porque o Estado se move por objetivos outros que não o mero interesse patrimonial direto (lucro), mas por valores como o desenvolvimento econômico, científico e social do país, a solução de problemas nacionais pela tecnologia, a abertura de fronteiras tecnológicas e industriais para a nação, a saúde pública em caso de novos medicamentos e vacinas, o fortalecimento de setores estratégicos para a soberania nacional tais como energia, defesa, comunicações, e inúmeras outras razões de índole pública decorrentes da razão de ser do Estado. O Estado também se vale da poupança pública formada pelos tributos, e assim pode sustentar pesquisas pelo tempo necessário para a construção de novos conhecimentos. É a incerteza no sentido apresentado por Frank Knight e sua oposição essencial ao lucro certo e garantido que marcam a separação entre a atuação do Estado e a do setor privado no 
empreendedorismo de novos conhecimentos e produtos. Não por acaso, em relação à realidade do Brasil, a Pesquisa de Inovação (PINTEC - 2011) do Instituto Brasileiro de Geografia e Estatística (IBGE), publicada em 2013 e abrangente do período 2009-2011, apontou que dentre os principais problemas e obstáculos à inovação segundo as empresas inovadoras do setor de indústria estão os custos, para $81,7 \%$ das empresas, e os riscos $(71,3 \%)^{6}$. Os dados demonstram que a ampla maioria das empresas inovadoras brasileiras analisadas identifica na incerteza e nos elevados custos dela decorrentes, marcados pela ausência de prognóstico de retornos, os principais gargalos ao desenvolvimento da inovação no setor industrial brasileiro. Trata-se, como temos sustentado, de característica própria do processo de desenvolvimento tecnológico, não apenas da realidade brasileira, mas de toda e qualquer tentativa de descoberta de novas fronteiras tecnológicas, de modo que não poderia deixar de ser sentida também por aqui, como identificado empiricamente pela pesquisa do IBGE.

No campo da incerteza e dos riscos, surge espaço para o Estado exercer sua função regulatória, no sentido de fomentar, controlar e conduzir os rumos do processo de desenvolvimento tecnológico. Cabe ao Estado realizar investimentos de longo prazo que não seriam feitos pela iniciativa privada, mas não de forma passiva, apenas fornecendo os recursos e a estrutura necessária para o setor privado conduzir as pesquisas e determinar qual o rumo do desenvolvimento, mas sim num papel ativo de identificação dos setores estratégicos para o desenvolvimento tecnológico do país, coordenando a canalização dos recursos humanos e materiais neste sentido, com o escopo de fomentar interações entre atores públicos e privados para projetos de pesquisa e desenvolvimento. O Estado deve ser protagonista na condução das pesquisas que viabilizam o desenvolvimento tecnológico, não se limitando à correção das falhas do mercado, nem apenas a viabilizar a estrutura necessária para a atuação do setor privado. Mazzucato (2014) dá o exemplo dos Estados Unidos na década de 1990, quando o governo Clinton reuniu seus formuladores de política e questionou qual seria a nova fronteira tecnológica a ser desbravada e que pudesse, nas décadas seguintes, manter a liderança econômica do país no mercado global. Concluiu-se pela necessidade de estabelecer uma política de pesquisa em inovação para a nanotecnologia, a qual se espera seja a nova tecnologia de propósito geral, sendo lançada a Iniciativa Nacional de Nanotecnologia (National Nanotechnology Iniciative), e desde então o Estado norte-americano vem mantendo

${ }^{6}$ BRASIL. Instituto Brasileiro de Geografia e Estatística. PINTEC 2011. Disponível em: <http://www.pintec.ibge.gov.br/downloads/pintec2011\%20publicacao\%20completa.pdf>. Acesso em: 01 jun. 2015. 
seus incentivos, sobretudo financeiros, para as pesquisas em nanotecnologia a fim de criar uma nova geração de produtos e processos que abram novas possibilidades de mercados e aplicações para os mais diversos setores da economia. Quais seriam as possibilidades de sucesso para a nanotecnologia no início da década de 1990? Não se sabia. Havia o cenário da incerteza. Desde aquela época até hoje, já se passaram mais de vinte anos de pesquisas, investimentos e de grande esforço do sistema de inovação norte-americano para a construção desta nova fronteira tecnológica. Tanto tempo e dinheiro empregados neste empreendimento tecnológico não teriam sido realizados pela iniciativa privada, que funciona visando ao lucro em horizontes de curto prazo. Somente através da liderança do Estado a Iniciativa Nacional de Nanotecnologia norte-americana tem se mantido por tanto tempo.

A função regulatória a ser exercida pelo Estado em pesquisa e inovação tecnológica é crucial para o sucesso desta estratégia como política de desenvolvimento. Se o Estado assume os riscos de investimentos em pesquisas nas fases iniciais em que a incerteza afasta investimentos privados, cabe a ele Estado dar o tom e o rumo das pesquisas no escopo de alavancar setores que interessam ao desenvolvimento nacional, para fortalecer o mercado interno e a competitividade do país no mercado internacional, gerar tecnologias que resolvam problemas nacionais em diversas áreas (pesquisa de vacina contra a dengue, por exemplo), elevem o nível de conhecimento nacional e, consequentemente, da qualidade de vida da população. A regulação da pesquisa em tecnologia e inovação por parte do Estado assume múltiplas formas, que vão desde o fomento por incentivos ficais (da qual a Lei do Bem, no 11.196/2005, talvez seja o principal exemplo no caso brasileiro) até linhas de investimentos diretos disponibilizados por instituições oficiais de fomento como o BNDES, passando por linhas orçamentárias mais robustas para as instituições públicas de pesquisas como as Universidades, e também por políticas e instrumentos que articulem atores privados e públicos da rede de inovação nacional, com a finalidade de viabilizar interações fecundas que gerem novas ideias. O conceito de rede de inovação é fundamental para o processo de desenvolvimento tecnológico nacional, e significa a difusão por toda a economia e sociedade de pessoas e instituições que trabalham e pesquisam inovações, amparadas pela implantação de infraestrutura necessária para a produção do conhecimento, rede na qual tais agentes podem interagir para fornecerem subsídios recíprocos em prol de projetos em P\&D, algo como o que acontece no Vale do Silício nos Estados Unidos, região marcada pela larga difusão de empresas e pessoas trabalhando em tecnologia e inovação, cenário fecundo para nova ideias e conhecimentos. 


\section{2 - Novas tecnologias, desenvolvimento econômico e criação de mercados}

Demonstrado que o Estado exerce o papel de financiar pesquisas que desenvolverão tecnologias inovadoras para novos produtos, o ponto central a ser agora abordado é que a introdução de novas tecnologias cria novos mercados e alimenta o desenvolvimento da economia. Joseph Schumpeter (2008) sustentou a ideia de que o desenvolvimento econômico é decorrência da criação de novas tecnologias que geram novos produtos e processos de produção e abrem novos mercados. O sistema capitalista é um modo de produção que se alimenta e se sustenta a partir da formação, de tempos em tempos, de novas tecnologias, formas de produção e da utilização de novas matérias-primas que instauram novo ciclo produtivo e realimenta a expansão econômica. A criação de novos produtos torna possível o surgimento de um novo mercado instaurado pela possibilidade de comercialização de mercadorias antes inexistentes. Schumpeter fala na "destruição criativa" como o processo em que a inovação elimina produtos até então comercializados, tornados obsoletos diante de uma nova geração tecnológica que se apresenta ao mercado, a qual realimentará a economia através da demanda pela aquisição dos novos produtos. Da mesma forma acontece quando há a introdução de novos métodos de produção, ou pela aplicação de nova matéria-prima, inovações que mudam o processo produtivo pela implantação de elementos novos que geram mercadorias melhores ou com preço menor. Foi o que ocorreu com inúmeros produtos que hoje são fundamentais na vida contemporânea: o automóvel, o avião, o telefone celular e depois o smartphone, as novas televisões, a Internet, todos decorrentes de tecnologias que instauraram novos padrões de comportamento, relações e consequentemente novos mercados. O mesmo se dá com a introdução de novos processos de produção (utilização de computadores, por exemplo) ou novas matérias-primas. Nas palavras do próprio Schumpeter (2008, tradução nossa):

O ponto essencial a ser compreendido é que, lidando com o capitalismo, estamos lidando com um processo evolutivo. (...)

Capitalismo, então, é por natureza uma forma ou método de mudança econômica e não só nem sempre, mas nunca, pode ser estacionário. (...) O impulso fundamental que estabelece e mantém o motor do capitalismo em movimento vem dos novos bens aos consumidores, dos novos métodos de produção ou transporte, dos novos mercados, das novas formas de organização industrial que o empreendimento capitalista cria.

A abertura de novos mercados, externos ou domésticos, (...) é que incessantemente revoluciona a estrutura econômica de seu interior, incessantemente destruindo uma 
velha estrutura, incessantemente criando uma nova. Esse processo de Destruição Criativa é o fato essencial sobre o capitalismo ${ }^{7}$.

Na visão schumpeteriana, empreender não é apenas abrir um negócio, reunir os fatores de produção necessários e desenvolver a atividade econômica. É, mais do que isso, ampliar horizontes mercadológicos, introduzir novos produtos e serviços para instaurar um novo mercado e alimentar o ciclo da produção econômica. Empreender é produzir novos conhecimentos que criarão novos produtos e, com estes, construir mercados. O capitalismo se alimenta da "destruição criativa" de uma geração de produtos e métodos de produção, substituídos pelo progresso tecnológico que lança novos bens no mercado e realimenta a demanda e o consumo de novos produtos, que por sua vez estimula a indústria na produção da nova geração de bens e serviços e impulsiona assim o ciclo do crescimento, ao mesmo tempo em que eleva o nível tecnológico, a riqueza da sociedade e também a qualidade dos produtos.

O papel do Estado, enquanto formulador de políticas industriais, é criar avanços que ampliem as fronteiras tecnológicas da economia pela inserção de produtos inovadores. Para tanto, cabe ao Estado assumir os riscos da fase de incertezas e capitanear pesquisas em setores estratégicos cujos riscos afastam o capital privado, avesso aos investimentos sem segurança do retorno lucrativo no curto prazo. O empreendedorismo do Estado em matéria de inovação tecnológica resulta de sua função institucional de promover o desenvolvimento, o que se faz, neste contexto, pela criação de novos mercados. A esta altura, é fundamental ter consciência sobre a natureza dos mercados e seus fundamentos. Aqui é essencial saber que os mercados são construções jurídicas formadas pela regulação estatal. Os mercados são arquiteturas jurídicas, porque gerados pela regulação/desregulação normativa implementada pelo próprio Estado. A compreensão deste fenômeno é o núcleo do trabalho seminal de Karl Polanyi (2012), no qual demonstrou que na sociedade contemporânea, em que os mercados estão na centralidade da organização social, os mercados tais quais hoje existentes surgiram com a regulação/desregulação jurídica promovida pelo Estado inglês no século 19, que mediante a revogação de determinadas leis e a criação de outras normas jurídicas viabilizou o

\footnotetext{
7 "The essential point to grasp is that in dealing with capitalism we are dealing with an evolutionary process. (...) Capitalism, then, is by nature a form or method of economic change and not only never is but never can be stationary. (...)

The fundamental impulse the sets and keeps the capitalism engine in motion comes from the new consumers' goods, the new methods of production or transportation, the new markets, the new forms of industrial organization that capitalism enterprise creates.

The opening up of new markets, foreign or domestic, (...) that incessantly revolutionizes the economic structure from within, incessantly destroying the old one, incessantly creating a new one. This process of Creative Destruction is the essential fact about capitalism." (SCHUMPETER, 2008).
} 
mercado de livre concorrência que depois se expandiu mundialmente. O mercado autorregulável, típico do liberalismo clássico (laissez-faire), não é outra coisa senão o fruto da regulação jurídica do Estado, que constrói as condições sobre as quais se estabelece e funciona. Em outras palavras, o mercado liberal clássico que funcionaria ou deveria funcionar sem a intervenção do Estado não passa de um mito sem comprovação histórica, porque seu surgimento e funcionamento dependem da forma como juridicamente é regulado, ou seja, é fruto da própria intervenção do Estado sem a qual não poderia existir.

Realmente, os mercados como os conhecemos hoje são arquiteturas jurídicas porque seus fundamentos são jurídicos. São quatro as condições sem as quais não há mercado como existe no mundo contemporâneo: (1) propriedade privada, (2) liberdade contratual, (3) garantia de cumprimento dos contratos (enforcement dos contratos) e (4) a presença de um sujeito supra partes que garanta o funcionamento do mercado e assegure direitos mínimos aos seus atores. Todos estes elementos são jurídicos ou ligados ao Estado. (1) A propriedade privada dos meios de produção é uma construção jurídica, pois é o direito que determina sua extensão, seus limites, sua função social, a forma de aquisição e de transmissão, em outras palavras, é o direito que constitui a propriedade (KENNEDY, 2011). (2) Da mesma forma, a liberdade contratual. Só há comércio e, portanto, mercado, onde as pessoas podem fazer trocas de mercadorias. A troca é o contrato elementar dos mercados, assim como a compra e venda. Não há mercado onde as pessoas, embora tenham a propriedade privada dos seus bens, não possam dispor delas, aliená-las segundo sua vontade. A liberdade contratual é um direito essencial para a constituição dos mercados porque a partir das relações de troca as operações elementares do mercado surgem e se desenvolvem progressivamente até atingirem a complexa rede global de agregados contratuais hoje existente. Portanto, a liberdade de como contratar e construir obrigações contratuais entre os atores do mercado é a própria liberdade contratual que o direito forma e determina em todos os seus elementos fundamentais, assim como o faz em relação à propriedade. (3) Igualmente, o enforcement (cumprimento) dos contratos assegurados pelo Estado, que estabelece institucionalmente órgãos para funcionarem supra partes na resolução de conflitos e assegurar que as obrigações sejam cumpridas, mantendo o funcionamento dos mercados. A eliminação da justiça privada e sua substituição pela justiça do Estado não é só uma condição essencial para a sociabilidade civilizada, mas também para a própria constituição e funcionamento pacífico e regular das relações de troca, em outras palavras, dos mercados. (4) Por fim, a manutenção do funcionamento dos mercados pela assunção do dever de proteção a direitos mínimos aos seus 
agentes é assegurada pelo próprio Estado, a instituição supra partes que mantém o respeito a direitos de convivência elementares como a integridade física do corpo e da propriedade privada, mesmo recorrendo à força se preciso. Os mercados são, portanto, arquiteturas jurídicas criadas pelo Estado para viabilizar e regular a atividade econômica da sociedade, sem a qual nenhuma população humana sobrevive. Aqui cabe uma distinção. A forma social da produção, distribuição e consumo dos bens essenciais à vida é o que constitui a economia. Não há sociedade sem economia. O comércio se dá com a existência de bens excedentes para uns e escassos para outros, de modo que os indivíduos de uma sociedade trocam entre si seus produtos (comércio interno), ou entre indivíduos de outras sociedades (comércio externo). $\mathrm{O}$ comércio é uma parte do processo econômico, notadamente aquela que envolve a distribuição dos bens produzidos em dada sociedade. Os mercados, por sua vez, são instituições mais sofisticadas de realização e controle do processo econômico de uma sociedade, mediante formas jurídicas que criam uma grande arquitetura (jurídica) abrangente da produção, distribuição/comercialização e consumo dos bens. No mundo contemporâneo, a economia se desenvolve no âmbito dos mercados, que são espaços jurídico-institucionais onde as relações econômicas são reguladas pelo Estado, por meio da composição de seus fundamentos essenciais: propriedade privada, liberdade contratual, enforcement dos contratos e proteção do seu funcionamento. Como foi dito, não há sociedade sem economia. Há, contudo, sociedade sem mercado, que é um artifício criado pelo Estado.

Em Polanyi (2012), vemos que no liberalismo do século 19 é adotada a premissa de que os mercados devem funcionar livres de qualquer intervenção do Estado para que, mediante autorregulação, supram suas deficiências pelo ajustamento dos preços mediante o mecanismo da oferta e da procura. Polanyi demonstrou que aquilo que se chama de autorregulação do mercado não é outra coisa senão a própria regulação jurídica do Estado sobre os mercados que permite o funcionamento destes sem restrições, especialmente restrições ligadas a elementos hoje essenciais como direitos trabalhistas, condições sanitárias de trabalho, valor dos salários. A autorregulação do mercado no sentido liberal clássico gerou naquele século um processo que conduziu ao aprofundamento da utilização do trabalho humano como mercadoria, sujeita ao mecanismo de preços influenciado pela lei da oferta e da procura, lançando populações imensas na pobreza na Inglaterra.

Apropriar-se da consciência de que os mercados são construções jurídicas e fruto da regulação estatal é fundamental para afastar discursos que sustentam o alheamento do Estado da economia, a fim de que possa desempenhar o papel que lhe cabe, notadamente pela 
ampliação econômica do mercado nacional a partir de novas fronteiras tecnológicas. $\mathrm{O}$ avanço tecnológico do mercado impulsionado pelo financiamento público deve ser acompanhado da regulação que difunda o desenvolvimento para setores que melhor atendam ao interesse público, mediante formas contratuais que assegurem a socialização da riqueza gerada e democratize o acesso a fontes de financiamento e à aquisição dos novos conhecimentos por toda a sociedade. A mentalidade de autorregulação do mercado, no sentido apregoado pelo laissez-faire, com o Estado passivamente concedendo fontes de financiamento para que o setor privado dê os rumos da pesquisa e do desenvolvimento nacional, significaria afastar o Estado do papel que lhe cabe por ser ele, como demonstrado, o real financiador das pesquisas, como também perder a oportunidade de atingir fins e valores que interessam à sociedade em geral, socializar a riqueza financiada com recursos públicos e impedir o funcionamento da economia que resulte em apropriação da riqueza por segmentos minoritários da sociedade.

\section{3 - Pressupostos conceituais do Estado Empreendedor}

Fincadas as premissas acima, podemos identificar os pressupostos conceituais do Estado Empreendedor.

O primeiro pressuposto conceitual do Estado Empreendedor é o de ser (1) financiador de pesquisas quando as incertezas de resultados afastam a iniciativa privada. Entretanto, o papel do Estado Empreendedor não se limita à mera subtração do risco do setor privado, nem à correção das falhas do mercado. O papel do Estado Empreendedor não é de coadjuvante, mas sim de protagonista do processo de desenvolvimento tecnológico. Em outras palavras, cabe ao Estado Empreendedor conduzir e orientar os rumos do desenvolvimento tecnológico. O papel do Estado é o de regular o setor da ciência, tecnologia e inovação nacionais, regular no sentido de conduzir e moldar este setor, ajustando e reajustando seus rumos segundo as necessidades de desenvolvimento nacional e para atender às demandas tecnológicas do mercado interno e da sociedade. É função do Estado Empreendedor, enquanto regulador do setor de pesquisa e desenvolvimento nacional, manejar seus instrumentos de fomento, financiamento e regulação para conduzir o desenvolvimento tecnológico rumo a atividades de interesse nacional, criando novas atividades econômicas no país, desenvolvendo outras ainda em estágios incipientes e de pouca competitividade internacional, gerando produtos que solucionem problemas nacionais e satisfaçam as 
demandas da economia doméstica, ou ainda criando capacidades tecnológicas que deem independência ao país frente a fontes externas, tais como segurança energética. O papel do Estado Empreendedor pressupõe uma política industrial permanente e em constante reavaliação para ajustes e correções de rumo, sempre com a meta do desenvolvimento tecnológico e econômico nacional.

O Estado Empreendedor como condutor do setor de pesquisa e desenvolvimento (P\&D) não significa a eliminação da liberdade de iniciativa privada, nem muito menos a captura do talento e da inventividade humana pela estrutura burocrática do Estado. Significa que cabe ao Estado detectar nichos tecnológicos deficientes e carentes de investimentos para desenvolvimento, de modo a direcionar seu financiamento para que tal setor se desenvolva. A condução feita pelo Estado é no sentido de prospectar campos para onde a economia nacional possa se desenvolver, sendo as novas tecnologias oriundas das pesquisas financiadas os mecanismos pelos quais novos horizontes poderão ser abertos para o país. Destarte, o segundo pressuposto do Estado Empreendedor é (2) ser condutor e orientador do desenvolvimento do setor de ciência, tecnologia e inovação nacional.

O terceiro pressuposto do Estado Empreendedor é (3) a orientação da política de pesquisa, desenvolvimento e inovação para a criação de novos produtos e serviços e respectivos mercados para a economia nacional. Trata-se de ser empreendedor no sentido que Schumpeter (2008) deu à palavra, mediante a regulação do setor de CT\&I e financiamento de pesquisas onde o capital de risco afasta iniciativa privada, para criação de novos mercados.

O papel desempenhado pelo Estado Empreendedor é de protagonismo, contudo não um protagonismo isolado, e sim articulado como o setor privado. Afastam-se do funcionamento do Estado Empreendedor as concepções que promovem a dicotomia públicoprivada, Estado-sociedade, Estado-mercados. Muito pelo contrário, o Estado Empreendedor reconhece a livre iniciativa como postulado fundamental, pela consciência de que as riquezas são geradas pelo empreendedorismo privado. Mais ainda, o Estado Empreendedor reconhece que para a inovação tecnológica é preciso criatividade e inventividade humanas, as quais somente com liberdade encontram espaço para seu pleno desenvolvimento. Por isso que o Estado Empreendedor busca viabilizar parcerias público-privadas em inovação e desenvolvimento tecnológico (sem excluir também a existência de projetos totalmente públicos) para a realização de pesquisas. O setor empresarial privado tem forte contribuição a dar na indicação das necessidades do setor industrial e para a canalização de pesquisas que 
solucionem demandas da economia nacional. O Estado, por sua vez, através dos seus mecanismos de financiamento, fomento e regulação, poderá apresentar (e criar) novas perspectivas para o setor privado nacional. Juntos, setor público e privado poderão se articular para o desenvolvimento tecnológico nacional. Por conseguinte, o quarto pressuposto conceitual do Estado Empreendedor é (4) a valorização de parcerias público-privadas para o desenvolvimento da inovação nacional.

A partir destes quatro pressupostos, chega-se à conclusão de que o Estado Empreendedor é uma dimensão do Estado Regulador (ARANHA, 2015), aquela que se refere ao setor de pesquisa e desenvolvimento. Não é o caso de esmiuçar aqui o conceito de Estado Regulador, mas tão somente de mencionar suas características fundamentais naquilo que permitam melhor definir o conceito de Estado Empreendedor, revelando pontos compartilhados entre ambos.

Nesse rumo, Estado Regulador ${ }^{8}$ é, em breve síntese, aquele que acima de tudo está comprometido com a realização plena de direitos fundamentais - inclusive econômicos e ligados à produção - através do gerenciamento permanente da realidade complexa, plural, multissetorial e em permanente alteração, a qual direciona seus mecanismos de intervenção políticas públicas principalmente - para condução e direcionamento de cada setor tendo como foco realização de direitos fundamentais. A regulação, que qualifica este modelo de Estado, está no permanente ajuste de seus mecanismos de intervenção na realidade - políticas públicas, instrumentos de fomento, normas em geral, fiscalização e sanções - face à conjuntura sempre em mudança da sociedade contemporânea global, na qual a velocidade das transformações decorrentes de tecnologias da informação e da comunicação aceleram a dinâmica das relações humanas.

O Estado Regulador não é o mesmo que Estado Liberal, porque não visa apenas proteger as liberdades individuais; não é Estado Mínimo, porque enxerga o mercado como uma realidade institucional que necessita da intervenção estatal; não é Estado Subsidiário, porque se mostra protagonista em diversos âmbitos e não se limita a atuar apenas após a

\footnotetext{
${ }^{8}$ Márcio Iorio Aranha (2015) identifica os pressupostos teóricos do Estado Regulador: “a) no Estado garante dos direitos fundamentais, inclusive a igualdade de condições competitivas; b) no Estado de intervenção permanente e simbiótica; c) no Estado Administrativo, por sua apresentação de agigantamento da função de planejamento e gerenciamento das leis; d) no Estado legitimado na figura do administrador, do processo de gerenciamento normativo da realidade ou do espaço público regulador; e) no Estado de direitos dependentes da sua conformação objetiva em ambientes regulados; f) no Estado Subsidiário, em sua apresentação de potencialização da iniciativa privada via funções de fomento, coordenação e fiscalização de setores relevantes; e g) no conceito de regulação como processo de realimentação contínua da decisão pelos efeitos dessa decisão, reconformando a atitude do regulador em uma cadeia infinita caracterizada pelo planejamento e gerenciamento conjuntural da realidade" (p. 33-34).
} 
atuação privada; não é Estado Social dado que, embora assuma o compromisso de efetivar direitos sociais, aceita a execução indireta de serviços pela iniciativa privada, e não enxerga as pessoas como meras usuárias de serviços públicos, mas como cidadãos que, juntos com o Estado, são protagonistas na efetivação de direitos fundamentais. O Estado Regulador tem, de certa forma, em todas as suas dimensões, elementos de todos estes tipos de Estado sem limitar-se a nenhum deles. Toma, na verdade, o arsenal instrumental e institucional dessas diversas formas de Estados para aplicá-los no gerenciamento permanente da realidade em seus múltiplos setores visando moldar comportamos em busca de realizar desenvolvimento social, econômico, político e ambiental, em outras palavras, a plena efetivação de direitos fundamentais.

Na busca desse desiderato pelo Estado Regulador há forte compromisso com a expertise técnica e administrativa, como decorrência do pressuposto de que a realidade contemporânea exige elevado grau de conhecimento sobre os setores regulados, para atingir eficiência na consecução dos seus fins. Por isso que o Estado Regulador supera a estrutura tripartite da teoria clássica da separação dos poderes para reconhecer que, pelo menos, existe uma função a mais desempenhada pelo Estado, a administrativa, que se distingue das demais legislativa, judiciária e executiva, por ser a função administrativa aquela em que o Estado efetivamente gerencia no âmbito da conjuntura fática cotidiana a aplicação das leis, distinguindo-se da função executiva caracterizada pela formação da decisão política em nível macro (WALDO, 2007). Por operacionalizar a função administrativa, o Estado Regulador emprega em seu funcionamento elementos da administração privada, mais ainda, busca formar parcerias com o setor privado. O Estado Regulador também cria novos arranjos institucionais e orgânicos para melhor desempenhar seu papel, os quais têm nas agências reguladoras independentes seus exemplos mais emblemáticos.

Por tudo isso, os pressupostos conceituais do Estado Empreendedor, se analisados com cuidado, ajustam-se ao que é o Estado Regulador. Chega-se à conclusão de que o Estado Empreendedor é na verdade o próprio Estado Regulador quando este se volta para o setor de ciência, tecnologia, inovação e desenvolvimento industrial, enfim, a dimensão do Estado Regulador que molda o setor tecnológico nacional rumo à plena maturação dos seus potenciais, dos direitos fundamentais a ele relacionados, em especial direitos de produção.

A esta altura, podemos tentar conceituar o Estado Empreendedor, numa definição sintética, como aquele que regula (conduz e molda) o setor de ciência, tecnologia e inovação 
visando à efetivação de direitos fundamentais e, mais especificamente, ao desenvolvimento tecnológico da indústria e do país.

Num conceito mais alargado, Estado Empreendedor é aquele que regula o setor de ciência, tecnologia e inovação para a criação de tecnologias que gerem soluções diversas para o país em termos de efetivação de direitos fundamentais, direitos de produção em destaque, em especial a criação de novos produtos e processos para abertura de mercados e ganhos de competitividade, mediante a assunção de riscos de financiamento de longo prazo a pesquisas cujas incertezas afastam a iniciativa privada, visando o desenvolvimento econômico e social do país, com ênfase em parcerias público-privadas.

\section{4 - A metalinguagem do Estado Empreendedor}

Para a compreensão mais aprofundada do Estado Empreendedor, para além dos pressupostos que formam seu conceito, é imprescindível mergulhar na sua metalinguagem. Por metalinguagem entendemos os pontos de partida de uma ideia ou concepção que, embora não estejam expressos do discurso, estão inseridos nele, impregnando suas formulações e os alicerces a partir dos quais o edifício teórico é erguido. A metalinguagem são os dogmas que estão implícitos em qualquer discurso que se veicula na linguagem. São as premissas das quais parte a ideia expressa numa linguagem, teoria ou, no caso aqui em análise, num determinado modelo de Estado.

O primeiro ponto da metalinguagem do Estado Empreendedor é o do intervencionismo do Estado na economia, nos mercados, na sociedade. O Estado Empreendedor recusa a ideia de que os mercados podem funcionar mediante autorregulação (HAYEK, 1980). Afasta a concepção de que ao Estado cabe apenas intervir para corrigir eventuais falhas dos mercados 9 . O Estado Empreendedor, por ser também Estado Regulador,

\footnotetext{
${ }^{9}$ E. K. Hunt, em sua História do Pensamento Econômico: Uma perspectiva crítica (2005), aponta Say, Senior e Bastiat como precursores da economia neoclássica. Segundo Hunt, os economistas neoclássicos apresentam em comum três pilares ideológicos, ainda que em versões às vezes diferentes: “(...) o argumento da mão invisível, segundo a qual as trocas no livre mercado harmonizavam os interesses de todas as pessoas, determinando 'preços racionais' e resultavam numa eficiente alocação de recursos. (...) a fé em que o livre-mercado conduziria automaticamente ao equilíbrio de pleno emprego. (...) a convicção de que a distribuição de renda era determinada pela produtividade marginal dos diferentes fatores de produção e que cada pessoa receberia como renda apenas o valor criado, na margem de produção, pelos fatores dessa pessoa" (p. 429430). Ainda segundo Hunt, os economistas neoclássicos dividem-se em duas vertentes: os conservadores, que sustentam o laissez-faire ortodoxo, sem qualquer interferência do Estado que não seja a proteção de direitos de propriedade e contratos, e consideram os males dos mercados consequências da interferência do Estado, vertente na qual estão Milton Friedman (Escola de Chicago), Carl Menger, Ludwig von Mises e Friederich A. Hayek, estes últimos da Escola Austríaca; os liberais,
} 
assume como sua função a intervenção no setor de CT\&I para conduzir os rumos do desenvolvimento industrial e tecnológico nacional. Através de mecanismos de fomento, regulamentação, financiamento e diversos outros, o Estado Empreendedor gerencia a conjuntura do setor de tecnologia nacional para ir moldando seu desenvolvimento de acordo com a política industrial, as necessidades de implementação de direitos fundamentais, da produção econômica e para solução de problemas nacionais.

Contudo, o intervencionismo do Estado Empreendedor não é avesso à liberdade de iniciativa, pelo contrário, defende-a como pressuposto, porque concebe a articulação entre o público e privado como fundamental para o desenvolvimento nacional. O Estado Empreendedor enxerga os mercados como um dos principais canais do desenvolvimento econômico e realização de direitos fundamentais. Vê no empreendedorismo privado o núcleo formador da inovação e a mola propulsora do aumento dos negócios na economia. Enfim, o dirigismo do Estado Empreendedor aceita o modo de produção capitalista, a economia de mercado, mas afasta, sim, a ideia liberal da autorregulação dos mercados.

Os mercados são compreendidos como ambientes institucionalmente criados $e$ regulados pelo Estado. Este é o segundo ponto da metalinguagem do Estado Empreendedor. Os mercados não são instituições que surgem naturalmente, em relação às quais o melhor que o Estado poderá fazer é não interferir em seu funcionamento porque naturalmente, através do seu livre funcionamento, os mercados irão equalizar os problemas de distribuição de riqueza e fruição de direitos funcionais. O Estado Empreendedor rejeita esta premissa liberal. Acolhe, por outro lado, a tese de Karl Polanyi (2012), segundo a qual os mercados são gerados pela regulação/desregulação normativa implementada pelo próprio Estado.

Estas percepções sobre a metalinguagem e o conceito de Estado Empreendedor não são meras discussões teóricas desprovidas de consequências práticas. São, na verdade, concepções de modelo de Estado que impactam em políticas públicas e no potencial regulatório estatal em termos de implementação de direitos fundamentais. Refiro-me aqui, em especial, que a metalinguagem do Estado Empreendedor se afasta de concepções teóricas existentes que, ao relacionarem direito e economia, prescrevem como solução para o desenvolvimento o reforço de direitos de propriedade e contratuais com o fim de fortalecer os mercados e seus atores - investidores principalmente. Segundo estas teorias, para que haja

neoclássicos que afirmam a necessidade de intervenção do Estado na economia para corrigir falhas ou imperfeições do mercado, através, por exemplo, de agências reguladoras e do direito antitruste, sendo Paul Samuelson um dos seus principais expoentes (p. 436-450). 
desenvolvimento o direito deve focar na propriedade e nos contratos, a fim de que os mercados de capitais prosperem, pois consideram que o crescimento dos mercados de capitais conduz à melhoria econômica do país. Estas são as conclusões principais da Law and Finance $^{10}$ (Direito e Finanças) (LA PORTA, et al, 1998) e da Nova Economia Institucional ${ }^{11}$ (NORTH, 1991). Ambas defendem a ênfase em direitos e instituições que tutelem os mercados de capitais. As boas instituições, segundo estas teorias, são aquelas que priorizam tais mercados, porque estes, uma vez consolidados e maduros, conduzirão à maior riqueza do país.

A consequência prática dessas teorias é a definição de um modelo uniforme de reformas institucionais e jurídicas a ser aplicado em qualquer país, tendo como referência a estrutura institucional de países onde, supostamente, os mercados de capitais são mais desenvolvidos, em geral países do sistema jurídico do common law. Neste rumo, o passo seguinte destas teorias é receitar transplantes institucionais espelhados em países que adotam instituições do common law para os países em desenvolvimento, como o Brasil (SCHAPIRO, 2010). O desenvolvimento somente é viável, segundo essas concepções teóricas, se o Estado fortalecer direitos e contratos que favoreçam os mercados de capitais.

O Banco Mundial, desde a década de 1980, através do programa para países em desenvolvimento denominado Doing Business ${ }^{12}$ (América Latina, África e países em transição do comunismo para o capitalismo), financiou diversas mudanças institucionais tendo com inspiração os postulados da Law and Finance e da Nova Economia Institucional. No Brasil, as mudanças institucionais realizadas a partir da influência do Banco Mundial resultaram na

\footnotetext{
${ }^{10} \mathrm{~A}$ Law and Finance (LF), também chamada de Teoria sobre as Origens, considera que determinados modelos institucionais são mais aptos que outros para promoção do desenvolvimento econômico. A partir de uma análise empírica comparativa entre países de origem no civil law e no common law, a LF conclui que as instituições jurídicas de tradição no common law são mais aptas à promoção do desenvolvimento, porque tendem a prestigiar e fortalecer direitos de propriedade e contratos. Consequentemente, a LF defende como receita de desenvolvimento o transplante de instituições do common law para todos os países, como forma de fortalecer o mercado de capitais, por entender que tal fortalecimento é pressuposto do desenvolvimento econômico. Em outras palavras, os recursos para a promoção do desenvolvimento devem ser buscados no fortalecimento do mercado de capitais.

${ }^{11}$ A Nova Economia Institucional (NEI), cujo principal expoente é o ganhador do Nobel em Economia Douglas North (1991), sustenta que as instituições importam para o desenvolvimento econômico e que este é mais propício nos países cujas instituições fortalecem as trocas de mercado, oferecendo um ambiente de negócios previsível, seguro, com regras definidas e que fortaleçam direitos de propriedade e contratos.

${ }_{12}$ O Programa Doing Business, do Banco Mundial, tem por escopo medir diversos fatores relacionados ao ambiente de negócios mediante análise comparativa entre vários países. São fatores como direitos de propriedade, diminuição de custos de resolução de controvérsias, aumento da previsibilidade nas relações econômicas, medidas de proteção contratual. A partir destas comparações, busca-se identificar elementos importantes na promoção do desenvolvimento dos negócios, a partir dos quais são propostas reformas para impulsionar o desenvolvimento econômico. A metodologia comparativa demonstra sua afinidade com a Law and Finance, e suas propostas de reformas institucionais tendentes ao florescimento dos negócios aproxima o Doing Business da Nova Economia Institucional.
} 
nova Lei de Falências, na nova Lei das Sociedades Anônimas, na Reforma do Judiciário, em novas regras de governança corporativa, todas visando o fortalecimento do mercado de capitais. Há ainda forte influência teórica no Brasil que pressiona por mudanças institucionais inspiradas no fortalecimento do mercado de capitais como caminho para o desenvolvimento, sustentando a inadequação do papel do Estado como indutor do desenvolvimento. Nilson Teixeira (2007), por exemplo, defende a redefinição do papel do Banco Nacional de Desenvolvimento Econômico e Social - BNDES. Este banco público tem sido um dos principais instrumentos da política industrial no Brasil desde meados do século passado (SCHAPIRO, 2010). Sustenta-se a necessidade de que o financiamento industrial no Brasil dê-se via mercado de capitais, com a retirada do BNDES desta função, eliminando-se como consequência os tributos que geram a fonte dos financiamentos deste banco público (TEIXEIRA, 2007).

$O$ Estado Empreendedor - e aqui chegamos ao terceiro ponto de sua metalinguagem - rejeita os postulados da Law and Finance e da Nova Economia Institucional. Assim o faz não porque seja contrário ao desenvolvimento do mercado de capitais no país, mas porque parte da premissa de que as instituições que promovem o desenvolvimento devem ser formadas segundo as características próprias de cada região. A tese dos transplantes institucionais é descartada pelo Estado Empreendedor. Como a realidade regulada é conjuntural, complexa e sempre em transformação, ela será intuitivamente diversa, rica em variedades culturais e respectivas demandas por soluções tecnológicas. Neste contexto, modelos uniformes inspirados na realidade social e econômica de determinados países não servem para promover o desenvolvimento de regiões com características próprias. O Estado Empreendedor nega a tese da dotação (endowment) que determinados modelos institucionais (do common law) teriam em promover o desenvolvimento. Acolhe, por outro lado, a tese do enraizamento (embeddness), segundo a qual os modelos de desenvolvimento devem ter raízes nas características locais. O mercado de capitais, importante para o desenvolvimento nacional, não é, contudo, sob a perspectiva do Estado Empreendedor, o único canal de transformação, devendo haver também instituições estatais e privadas que se articulem com os elementos típicos de cada região e suas idiossincrasias culturais. O Estado Empreendedor se aproxima, portanto, de concepções teóricas sobre direito e economia que reconhecem o papel do Estado no desenvolvimento, a exemplo do Novo Direito e 


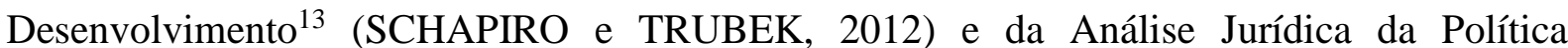
Econômica $^{14}$ (CASTRO, 2014).

${ }^{13}$ O Novo Direito e Desenvolvimento (NDD) tem por objeto de estudo os países em desenvolvimento que, como o Brasil, ainda não concluíram o processo de maturação econômica e tecnológica e enfrentam diversos problemas estruturais e sociais. O que caracteriza o NDD é o foco na criação de alterativas de desenvolvimento específicas para cada país, levando em consideração suas peculiaridades econômicas, culturais, políticas e sociais. Afasta, dessa forma, propostas de desenvolvimento baseadas em transplantes institucionais de determinados contextos para outros, por entender que o direito e as instituições de cada local, com suas idiossincrasias, repercutem na economia e exigem políticas e estratégias específicas. Por essa razão, o método do NDD para construção de suas propostas vale-se do experimentalismo, principalmente de novos arranjos institucionais que destaquem os potenciais de cada país, região ou localidade, salientando a descoberta de aptidões econômicas; do diálogo horizontal com outros países e regiões na busca de modelos alternativos e criativos de desenvolvimento, a exemplo do diálogo entre os BRICS (Brasil, Rússia, Índia, China e África do Sul), para, através da experiência dos outros, aperfeiçoar estratégias de desenvolvimento e evitar erros cometidos; e do pragmatismo democrático, por meio do qual a comunidade destinatária da política é ouvida e chamada a participar da construção das alternativas viáveis de desenvolvimento.

Fala-se em "Novo" Direito e Desenvolvimento (NDD) porque, de certa forma, representa o resgate das teorias de desenvolvimento dos anos 1950-1980, por meio das quais se propunham alternativas de alavancagem econômica dos países não desenvolvidos com políticas industriais e de desenvolvimento inovadoras. Nesse primeiro momento, segundo Schapiro e Trubek (2012), havia o predomínio da teoria do desenvolvimento, a primazia do Estado no papel e o direito público como vetor de transformação. Com o esgotamento deste modelo nos anos 1980, principalmente em razão de sérios problemas econômicos enfrentados pelos países emergentes, abriu-se espaço para o predomínio das concepções formuladas no Consenso de Washington, com base nas quais o mercado substituiu o Estado como protagonista do desenvolvimento, o direito público cedeu lugar para o privado, com foco em direitos de propriedade e contratos, e a teoria do desenvolvimento foi substituída pela desregulamentação dos mercados e a adoção do modelo de transplantes institucionais dos países desenvolvidos para os emergentes, com o patrocínio de grandes organizações internacionais como o Banco Mundial e o Fundo Monetário Internacional, o que resultou em liberalização dos mercados, no aumento do livre fluxo internacional de capitais, privatizações de empresas públicas, redução do tamanho do Estado, dentre outras reformas institucionais.

Como esse modelo pró-mercado não resultou na solução dos problemas dos países emergentes, acabou abrindo campo para a retomada das teorias desenvolvimentistas do primeiro momento, especialmente após a grave crise financeira mundial de 2007/2008. Ocorre que o Novo Direito e Desenvolvimento, além das características mencionadas acima, apresenta viés distinto do primeiro, pois tenta conciliar os papéis de Estado e mercado/sociedade na condução do desenvolvimento. De certa forma, o NDD traz características dos modelos anteriores, evitando criar a dicotomia público-privado, Estado-mercado, por entender que todos os atores são fundamentais no desenvolvimento. Lauro Mattei (2013) afirma que "na estratégia 'novo desenvolvimentista' o Estado continua tendo papel de destaque, porém com funções distintas daquelas exercidas no período anterior". Segundo o autor, o Estado deve "(...) ter a capacidade para regular a economia, estimulando um mercado forte e um sistema financeiro a serviço do desenvolvimento e não das atividades especulativas (...)”.

${ }^{14}$ A Análise Jurídica da Política Econômica (AJPE) possui abordagem que fornece elementos analíticos da realidade empírica e de políticas públicas pela perspectiva da fruição de direitos fundamentais. Os procedimentos analíticos da AJPE são dois: a análise posicional e a nova análise contratual. A primeira tem por finalidade identificar o estado de fruição de um direito fundamental em determinado contexto local, nacional, regional ou global. A nova análise contratual, por sua vez, preocupa-se em identificar os elementos constitutivos dos agregados contratuais por meios dos quais os direitos fundamentais são acessados, especialmente visando avaliar criticamente tais elementos perquirindo sobre seus reflexos sobre a fruição de direitos fundamentais, com o fim de propor reformas que permitam superar déficits de direitos fundamentais.

A análise posicional possui cinco etapas por meio das quais são dissecados a política pública analisada e o direito a ela relacionado: (1) o relacionamento da política analisada a um determinado direito fundamental de produção ou de consumo; (2) a decomposição analítica do conteúdo relacional dos direitos subjetivos, que significa a identificação de outros direitos ou elementos sem os quais o direito fundamental relacionado à política pública não poderá ser fruído satisfatoriamente; (3) a quantificação da fruição do direito no contexto empírico analisado, pela qual será apurado o quão concreto e efetivo é cada um dos elementos apontados na etapa anterior como essenciais para a fruição do direito fundamental relacionado com a política pública analisada, formando o Índice de Fruição Empírica (IFE); (4) definição quantitativa de um Padrão de Validação Jurídica (PVJ), que reflete o grau de qualidade que os serviços e a infraestrutura em torno do direito fundamental 
O Estado Empreendedor, sendo o Estado Regulador em atuação sobre o setor de CT\&I nacional, concebe os mercados como ambientes sobre os quais necessariamente sua regulação deverá incidir, a fim de, mediante articulação com o setor privado e respeitando a liberdade deste, promover o desenvolvimento tendo como instrumentos instituições e políticas concebidas a partir de enraizamento nas peculiaridades locais.

\section{5 - Conclusão do capítulo}

De certa forma, o Brasil já conhece o caminho do desenvolvimento econômico através da inovação e criação de novos mercados. A experiência brasileira na agropecuária, marcada pela intensa pesquisa da Embrapa, e com outras de suas empresas públicas, demonstra que o país já trilhou em alguns setores o caminho da criação de atividades econômicas que antes não exercia, conquistando mercados inclusive internacionais. Cabe agora ao Brasil ampliar sua experiência bem-sucedida nos setores mencionados e constituir uma rede de inovação e pesquisa difusa por toda a economia, abrangente de diversos agentes públicos e privados, com um arcabouço jurídico-institucional moderno, diversificado e complexo, a fim de que novos setores econômicos surjam, haja seu ingresso em novos mercados e que produtos e processos com aplicação intensiva de conhecimento sejam a

devem ter, de acordo com as expectativas da comunidade, para que o direito seja considerado plenamente fruído; (5) a elaboração de propostas de reformas da política pública avaliada, levando em consideração o IFE e o PVJ formados, tendo em mira a plena fruição do direito fundamental em jogo pela comunidade destinatária da política. A análise posicional tem como virtude evitar conceitos abstratos e fechados, abrindo-se para as múltiplas formas que os direitos fundamentais - e as políticas públicas que os efetivam - podem assumir segundo o contexto social, humano e cultural de cada localidade. Por essa razão, a AJPE tem como pressuposto o diálogo com os destinatários das políticas públicas.

A Nova Análise Contratual (também chamada de Análise de Portfólio) foca as cláusulas presentes nos agregados contratuais, por entender que nas sociedades de mercado do mundo contemporâneo o acesso à fruição de direitos passa necessariamente pela complexa e interligada rede de arquiteturas contratuais que favorecem ou impedem a fruição empírica de direitos fundamentais. A análise das cláusulas contratuais poderá revelar elementos que geram déficits de direitos fundamentais. A AJPE considera que os contratos podem ter cláusulas de utilidade, quando se referem a um bem ou serviço da economia real, ou cláusulas monetárias, quando envolvem dinheiro ou ativo da economia financeira. Tanto as cláusulas de utilidade quanto as monetárias podem ter conteúdos de interesse privado, negociados livremente pelas partes, quanto conteúdos de interesse público, quando impostos pelo Estado, geralmente por lei, tributos por exemplo. A nova análise contratual tem ainda a virtude de revelar o fenômeno da deflexão monetária interportfólio, caracterizada pela transmissão na rede de agregados contratuais de elementos presentes nos contratos, como as taxas de juros, que impactam nos direitos fundamentais.

A articulação dos elementos revelados pela análise posicional e pela nova análise contratual permite a consciência sobre os processos que impactam sobre direitos fundamentais e leva, por consequência, à reflexão sobre alternativas para superar os déficits de fruição de direitos. Permite ainda que se construa um liame entre a política pública analisada e suas implicações jurídicas, notadamente através das cláusulas de interesse público presentes nos contratos, por meio das quais o Estado, mediante lei ou qualquer outro mecanismo jurídico válido, pode manejar instrumentos para perseguir objetivos considerados de interesse público. 
característica principal da economia nacional, ainda hoje marcada pela preponderância das exportações de bens primários.

Identificado o papel do Estado no desenvolvimento tecnológico e em que consiste o Estado Empreendedor, cumpre agora investigar se a Constituição Federal, quanto às normas voltadas à política de ciência, tecnologia e inovação, autoriza a postura empreendedora do Estado brasileiro no sentido abordado acima. Este será o objeto do próximo capítulo: analisar se a Constituição Federal confere base jurídica para um Estado Empreendedor em matéria de pesquisa e desenvolvimento tecnológico. 


\section{CAPÍTULO 2 - PRESSUPOSTOS CONCEITUAIS DO ESTADO EMPREENDEDOR NA CONSTITUIÇÃO FEDERAL DE 1988}

Cumpre agora voltarmos os olhos para a Constituição Federal de 1988 com o objetivo de identificar elementos do Estado Empreendedor em suas disposições normativas. Tentaremos responder à seguinte questão: que relação existe entre os elementos conceituais do Estado Empreendedor e a política de CT\&I brasileira pós-Constituição Federal de 1988 ? Em outras palavras: a Constituição Federal optou pelo funcionamento do Estado brasileiro, no setor de ciência, tecnologia e inovação, como Estado Empreendedor?

O objetivo não é esgotar a análise do texto constitucional sobre CT\&I, mas tão somente daquilo que for necessário para demonstrar que o modelo constitucional brasileiro adota o do Estado Empreendedor. Para percorrer este caminho, procuraremos nas disposições constitucionais normas que expressem os pressupostos conceituais do Estado Empreendedor demonstrados acima, bem como sua metalinguagem.

Nossa base empírica de análise são as normas constitucionais estabelecidas no ordenamento jurídico brasileiro, não apenas aquelas do capítulo que trata da ciência, tecnologia e inovação (arts. 218 -219-B), mas de todo o texto constitucional, naquilo que seja direta ou indiretamente ligado ao setor de CT\&I, notadamente as normas da ordem econômica. Recentemente, a Emenda Constitucional no $85^{15}$ deixou ainda mais explícitos os objetivos constitucionais no setor. O ponto de partida está no art. 218 da Constituição, que confere diversos elementos fundamentais para alcançarmos o objetivo aqui traçado.

$\mathrm{O}$ art. 218, caput, prescreve: “O Estado promoverá e incentivará o desenvolvimento científico, a pesquisa, a capacitação científica e tecnológica e a inovação”.

Logo em seus parágrafos iniciais, especificamente no primeiro e no segundo parágrafos, o mesmo artigo dispõe:

A pesquisa científica básica e tecnológica receberá tratamento prioritário do Estado, tendo em vista o bem público e o progresso da ciência, tecnologia e inovação.

A pesquisa tecnológica voltar-se-á preponderantemente para a solução dos problemas brasileiros e para o desenvolvimento do sistema produtivo nacional e regional.

\footnotetext{
${ }^{15}$ De 26 de fevereiro de 2015, publicada no Diário Oficial da União de 27 de fevereiro de 2015.
} 
Tem-se aqui, claramente, disposições constitucionais que albergam três dos pressupostos conceituais do Estado Empreendedor.

A Constituição Federal atribui ao Estado brasileiro o dever de promover e incentivar o desenvolvimento da ciência, tecnologia e inovação nacionais. Interessa-nos aqui, mais especificamente, o dever de promoção (promover) atribuído ao Estado. Promover significa fornecer meios para que algo aconteça, dar impulso para a realização de alguma coisa, ser causa de algo. Em outras palavras, ao Estado cabe criar as condições necessárias para que haja desenvolvimento científico e tecnológico no país. Claudia Lima Marques (2013) afirma existir uma "função promocional do Estado em relação ao desenvolvimento científico, pesquisa em geral e capacitação tecnológica". Ademais, como a Constituição usou os verbos promover e incentivar, significa dizer que ao Estado não cabe apenas fomentar (incentivar) o desenvolvimento da CT\&I, mas também adotar processos concretos diretamente em prol da realização do escopo constitucional. Esta promoção deverá ser, em essência e principalmente, no financiamento de pesquisas quando as incertezas de resultados afastam a iniciativa privada (primeiro pressuposto conceitual do Estado Empreendedor), tendo em vista que é da pesquisa básica que surge conhecimento essencial para a pesquisa aplicada geradora de inovações em produtos e processos, e por ser da pesquisa básica que o capital privado se afasta diante do cenário de incertezas quanto ao retorno financeiro dos investimentos.

Além do financiamento público a pesquisas em ambientes de incerteza, a promoção do desenvolvimento da ciência e tecnologia pelo Estado deve se dar também na construção de ambiente favorável às pesquisas. Refiro-me aos investimentos em infraestrutura material e humana sem os quais as pesquisas não ocorrem: laboratórios adequados e devidamente equipados, tecnologia da informação e comunicação, redes de computadores e dados, pesquisadores capacitados, universidades para formar pesquisadores, acesso a mercados fornecedores de produtos e equipamentos para as pesquisas, intercâmbio com outros países e centros de pesquisa estrangeiros, pagamento de bolsas para estudos no exterior, vinda de pesquisadores de outros países, integração entre centros de pesquisas nacionais, dentre outros. Em relação ao material humano, é dever do Estado, mas palavras de Claudia Lima Marques (2013), a "formação, aperfeiçoamento e ensino de pesquisadores, cientistas e técnicos", o que a autora denomina de "capacitação tecnológica", como um dos focos da função promocional do Estado em pesquisa científica. Trata-se da dimensão objetiva dos direitos - no caso, um direito de produção - a qual, para além da dimensão subjetiva que analisa o titular dos direitos, preocupa-se com todos os elementos concretos - materiais e 
humanos - necessários para realizar determinado direito, ou seja, a dimensão objetiva volta-se para a infraestrutura subjacente aos direitos, sendo dever típico do Estado Regulador orquestrar todos os elementos e diversos mercados envolvidos para tornar possível a fruição empírica de um direito assegurado juridicamente. A Constituição Federal, é importante frisar, adota a metalinguagem do Estado Regulador em matéria de ciência e tecnologia. Dito de outro modo, a Constituição Federal rejeita percepções do determinismo tecnológico segundo as quais o desenvolvimento econômico e social virá como consequência do desenvolvimento das tecnologias, e que estas surgirão quase que espontaneamente, ou pelo atuar das forças do mercado. Tais concepções têm claro viés utópico ao crerem numa espécie de salvação através da tecnologia, sem prescreverem qualquer plano concreto de atuação por meio do qual tais tecnologias surgirão. Pelo prisma da Constituição Federal, o Estado deverá promover o desenvolvimento tecnológico. Cabe ao Estado criar as condições objetivas para que as pesquisas sejam realizadas e delas surjam tecnologias promotoras do desenvolvimento. $\mathrm{O}$ progresso tecnológico pressupõe forte e ordenada atuação regulatória do Estado (WILSON, 2006).

No papel de promotor do desenvolvimento tecnológico, o Estado deverá orientar a pesquisa científica básica e tecnológica (aplicada) para o bem público e o progresso da CT\&I nacional, conforme dispõe do parágrafo $1^{\circ}$ do art. 218 da Constituição, que explicitamente determina que o Estado brasileiro seja condutor e orientador do desenvolvimento do setor de ciência, tecnologia e inovação nacional (segundo pressuposto conceitual do Estado Empreendedor).

Por bem público - conceito vago e indeterminado - devemos entender, utilizando interpretação de cunho sistemático do texto constitucional, a realização dos objetivos fundamentais da República Federativa do Brasil previstos em seu art. 3o-: construir uma sociedade livre, justa e solidária; garantir o desenvolvimento nacional; erradicar a pobreza e a marginalização e reduzir as desigualdades sociais e regionais; promover o bem de todos, sem preconceitos de origem, raça, sexo, cor, idade e quaisquer outras formas de discriminação. Em se tratando de ciência e tecnologia, quanto à classificação entre direitos de consumo e de produção, ambas (ciência e tecnologia) estão mais diretamente ligadas ao segundo tipo, ou seja, direitos de produção, por meio dos quais serão gerados os bens, serviços e processos que permitirão a fruição empírica de direitos fundamentais pela sociedade e maior competitividade para as empresas nacionais. Como já mencionado acima, na atual sociedade, os mercados são instrumentos (arquiteturas) jurídicos por meio dos quais o Estado regula a 
produção e o consumo. Assim, o Estado, ao criar mercados e regular seu funcionamento, está indiretamente regulando e viabilizando a oferta de bens e serviços que permitirão a fruição concreta de direitos fundamentais pelas pessoas. Basta mencionar, como exemplo, o mercado de medicamentos, essencial para garantia do direito fundamental à saúde. Na ausência de medicamento para tratamento de doença - podemos citar a dengue -, o Estado, segundo a Constituição Federal, promoverá pesquisas para criação de medicamento preventivo ou curativo, pesquisas cujos resultados poderão colocar novo medicamento no mercado, por meio do qual a população terá acesso ao tratamento e à fruição empírica do direito à saúde. Percebe-se deste modo a ligação existente entre pesquisa científica, tecnológica e de inovação, mercados e direitos fundamentais. A realização deste ciclo atende ao bem público (bem comum) se permitir a realização plena de direitos fundamentais. Para Claudia Lima Marques, Rosângela Cavallazzi e Bruno Miragem (2013), o bem público mencionado no art. 218, §1ํㅡㄹ da Constituição Federal significa os benefícios decorrentes da pesquisa científica, em seu papel de impulsionadora de novos conhecimentos que geram desenvolvimento e progresso contínuo. Em outras palavras, a pesquisa científica gera o conhecimento que produz soluções para as demandas sociais e econômicas da nação, construindo assim seu desenvolvimento, e nisso consiste o bem público. Para tanto, a pesquisa tem que ser dirigida pelo Estado, não no sentido de controle sobre a inventividade e a genialidade humanas, que não podem ser sufocadas pela burocracia administrativa, mas direção das pesquisas a fim de criarem soluções para problemas nacionais, seja para a população e seus direitos fundamentais, seja para a indústria em busca de maior competitividade internacional. $\mathrm{O}$ Estado deve procurar nichos de desenvolvimento para ampliar a base produtiva nacional, identificar fraquezas da indústria doméstica e observar quais as demandas tecnológicas existentes para solucionar problemas, canalizando seus investimentos para direcionar as pesquisas neste sentido. Aqui se faz presente a prescrição do parágrafo segundo do art. 218 da Constituição Federal, em que há preocupação com a resolução dos problemas brasileiros e com o desenvolvimento do sistema produtivo nacional e regional.

A relação entre CT\&I e mercados, notadamente o mercado nacional, fica evidente no perfil constitucional do Estado brasileiro prescrito no art. 219, segundo o qual "o mercado interno integra o patrimônio nacional e será incentivado de modo a viabilizar o desenvolvimento cultural e sócio-econômico, o bem-estar da população e a autonomia tecnológica do País, nos termos de lei federal”. 
Fica claro que a Constituição Federal determina ao Estado brasileiro a orientação da política de pesquisa, desenvolvimento e inovação para a criação de novos produtos e serviços e respectivos mercados para a economia nacional (terceiro pressuposto conceitual do Estado Empreendedor). Em outras palavras, o Estado brasileiro tem a função de promover a CT\&I nacionais para desenvolver o mercado interno, de modo que seja mais competitivo no exterior, forneça os bens e serviços que gerem bem-estar à população e confira independência tecnológica ao país. A Constituição Federal aceita a tese de que a inovação tecnológica abre e desenvolve mercados e que estes, por sua vez, geram riqueza e bem-estar à população, cabendo ao Estado impulsionar esta relação de causalidade por meio de novas tecnologias.

Toda essa função atribuída ao Estado brasileiro pela Constituição no setor de CT\&I é perpassada pela relação público-privada. O art. 219-A prescreve:

\begin{abstract}
A União, os Estados, o Distrito Federal e os Municípios poderão firmar instrumentos de cooperação com órgãos e entidades públicos e com entidades privadas, inclusive para o compartilhamento de recursos humanos especializados e capacidade instalada, para a execução de projetos de pesquisa, de desenvolvimento científico e tecnológico e de inovação, mediante contrapartida financeira ou não financeira assumida pelo ente beneficiário, na forma da lei.
\end{abstract}

Mais que uma faculdade, a Constituição toma como fundamental a formação de parcerias público-privadas em inovação, inclusive dispõe no art. 219-B que "o Sistema Nacional de Ciência, Tecnologia e Inovação (SNCTI) será organizado em regime de colaboração entre entes, tanto públicos quanto privados, com vistas a promover o desenvolvimento científico e tecnológico e a inovação".

Aqui, tem relevo constitucional o papel das universidades públicas na realização de pesquisas e promoção da inovação. O art. 207 da Constituição Federal prevê que as universidades são regidas pelo princípio da indissociabilidade entre ensino, pesquisa e extensão, e, no art. 213, §2o, dispõe: “As atividades de pesquisa, de extensão e de estímulo e fomento à inovação realizadas por universidades e/ou por instituições de educação profissional e tecnológica poderão receber apoio financeiro do Poder Público”.

Nesse contexto, abre-se o caminho para a interação universidade-empresa, notadamente através da rede federal de universidades espalhadas por todo o país, que tem o potencial de gerar um ecossistema de inovação integrado com o setor produtivo de todas as regiões nacionais. Faz-se presente no texto constitucional, portanto, a valorização de parcerias público-privadas para o desenvolvimento da inovação nacional (quarto pressuposto conceitual do Estado Empreendedor). 
A Constituição Federal, como demonstrado, reúne em suas disposições normativas todos os elementos conceituais do Estado Empreendedor, entendido como a dimensão do Estado Regulador em atuação sobre o setor de CT\&I, com o fim de promover seu desenvolvimento mediante o financiamento de pesquisas cujas incertezas de resultados desestimulam a iniciativa privada, processo no qual o Estado conduz e direciona o desenvolvimento tecnológico para solução dos problemas nacionais e em benefício do mercado doméstico, com a ampliação de mercados e inserção competitiva no comércio internacional mediante concorrência com produtos inovadores, sendo todo este processo construído, em especial, através de parcerias público-privadas em projetos de inovação. Em outras palavras, pode-se afirmar que a Constituição Federal do Brasil adotou o modelo do Estado Empreendedor para sua política industrial e de pesquisa, desenvolvimento e inovação.

Outrossim, se analisarmos com maior profundidade o modelo de Estado adotado pela Constituição Federal e as funções que esta inseriu em tal modelo, veremos que também os pressupostos metalinguísticos do Estado Empreendedor são acolhidos no texto constitucional.

Para revelá-los, é preciso interpretar as normas constitucionais sobre a ordem econômica, articulando-as com as que disciplinam o setor de ciência, tecnologia e inovação. Isso porque ambos os capítulos do texto constitucional estão interligados, não só porque fazem parte de um mesmo sistema constitucional, mas principalmente porque a realidade empírica a qual estas normas se voltam é uma só, com fenômenos que se entrelaçam. Com efeito, falar de CT\&I implica falar de mercados e estes são os espaços onde a atividade econômica é regulada pelo Estado. Consequentemente, as normas da ordem econômica refletem sobre a política de CT\&I e esta, por sua vez, produz efeitos sobre a atividade econômica. Forma-se um todo interligado na realidade empírica que não pode ser desprezado por juristas e formuladores de políticas públicas.

Para compreender a metalinguagem da Constituição Federal, o passo inicial é observar que, em matéria de atividade econômica - entendida como a organização dos recursos necessários para a produção, troca e consumo de bens e serviços - ao Estado cabe tão somente realizá-la em caráter excepcional, apenas para atender aos imperativos de segurança nacional ou a relevante interesse coletivo (art. 173 da Constituição Federal). Isso significa que a Constituição considera que o espaço da atividade econômica é, em regra, reservado à sociedade civil, ao âmbito privado, não sendo assunto estatal sua exploração direta. A Constituição atribuiu a titularidade dos direitos de produção aos particulares. Não cabe ao 
Estado gerar riqueza, mas ao empresariado. Somente quando a iniciativa privada não se organizar para produzir bens e serviços a ponto de tal situação ameaçar a segurança nacional ou periclitar qualquer outro elemento de relevante interesse coletivo, aí sim a Constituição autoriza o Estado a realizar a atividade econômica, substituindo-se ao setor privado.

A Constituição Federal, ao estabelecer como princípio da ordem econômica a propriedade privada (art. 170, II), que não é outra senão a propriedade privada dos meios de produção, optou claramente pelo sistema capitalista de produção, mas não o capitalismo de Estado $^{16}$, dado que o Estado apenas excepcionalmente explora atividade econômica. E indo mais a fundo, ao Estado não apenas não cabe explorar atividade econômica, como também não cabe a ele dirigi-la, isto é, deixa-se que os particulares decidam quando, o que e de que forma produzir, reunindo sem intervenção estatal os recursos necessários para a realização da empresa, sendo este o núcleo fundamental da liberdade de iniciativa, elevada à condição de fundamento da ordem econômica na Constituição do Brasil.

Sendo assim, pergunta-se: se ao Estado não cabe explorar (salvo excepcionalmente) atividade econômica, nem dirigi-la, qual o seu papel em relação à atividade econômica no país?

A própria Constituição Federal fornece a resposta através dos fundamentos e princípios que estruturam a ordem econômica. Ou seja, embora tenha feito a opção pelo sistema capitalista de produção econômica, no qual a propriedade dos meios de produção é privada, e que esta atividade econômica não sofre o dirigismo estatal, isto é, aos agentes econômicos da sociedade civil seja reconhecido o direito à liberdade de iniciativa, tais opções jurídico-econômicas não são livres em absoluto, mas encontram limites em outros princípios e fundamentos da ordem econômica. Refiro-me que, embora a propriedade seja privada, ela deverá atender à sua função social (art. 170, III); embora haja liberdade de iniciativa (liberdade de decidir o que, quando e como produzir), ela estará condicionada ao respeito ao meio ambiente (art. 170, VI) e aos direitos dos consumidores (art. 170, V); está limitada ao fato de o Estado lançar mão de mecanismos (tributários, para citar um dos mais relevantes)

${ }^{16} \mathrm{O}$ capitalismo é o sistema econômico em que os meios de produção (recursos disponíveis para a realização da atividade econômica) são privados, ou seja, não são coletivos, pertencem a um ou mais proprietários definidos que podem usar, gozar e dispor desses meios conforme suas livres vontades. No capitalismo de Estado o proprietário dos meios de produção é o Estado, que realiza a atividade econômica. Importante ressaltar que, segundo a Constituição Federal do Brasil, o capitalismo de Estado que o art. 173 torna excepcional é o que historicamente teve seu auge no século 20, definido por Musacchio e Lazzarini (2015) como aquele em que "os governos são proprietários e gestores de empresas estatais (SOES), como extensões da burocracia pública" (p. 10). Conforme os referidos autores demonstram, no século 21 têm surgido novas formas de capitalismo de Estado em que o Poder Público não é o proprietário da integralidade da empresa, mas atua ora como acionista majoritário, ora como minoritário, de forma conjunta com o capital privado, inclusive muitas vezes sem poder de controle sobre as empresas em que possui participações acionárias. 
que busquem a redução das desigualdades regionais e sociais (art. 170, VII), o pleno emprego (art. 170, VIII), o tratamento favorecido às empresas de pequeno porte (art. 170, IX) e à valorização do trabalho humano, em atendimento aos princípios e fundamentos que regem as relações econômicas no Brasil. O capitalismo no Brasil não se dá numa ordem econômica liberal, na qual a economia se autorregula, mas sim numa ordem econômica intervencionista (GRAU, 2014), em que o Estado atua, com autorização constitucional, para orientar a atividade econômica nos trilhos da concretização de valores fundamentais sem os quais princípios e direitos constitucionais não alcançam realização.

Voltando à pergunta formulada sobre o papel do Estado, respondemos: cabe a ele intervir na economia para que os fundamentos e princípios da ordem econômica sejam concretizados, assegurando a propriedade privada, mas cuidando para que esta cumpra sua função social, garantindo a livre concorrência e a liberdade de iniciativa, mas zelando para que não violem os direitos dos consumidores nem o meio ambiente, estimulando a economia para que haja pleno emprego, redução das desigualdades e favorecimento das pequenas empresas, mas tributando a atividade econômica para que parcela da riqueza gerada seja revertida em prol da comunidade em geral. Enfim, o papel do Estado é regular a economia, para que direitos liberais e sociais, direitos fundamentais em geral, sejam realizados na proporção adequada em que valores tão antagônicos possam assegurar o bem-estar da sociedade em geral. A Constituição Federal tem os mesmos pontos de partida do Estado Regulador e, consequentemente, do Estado Empreendedor, por considerar ser função do Estado a regulação da economia e dos mercados para realização de direitos fundamentais, rejeitando o dogma liberal da autorregulação dos mercados (primeiro pressuposto metalinguístico). Não poderia ser de outra forma, eis que para assegurar valores como trabalho, meio ambiente, direitos do consumidor, desenvolvimento tecnológico, proteção às micro e pequenas empresas, dentre outros, somente por meio da regulação da economia pelo Estado através dos seus diversos mecanismos de intervenção.

O primeiro pressuposto metalinguístico da Constituição Federal conduz ao segundo, dele decorrente, que considera os mercados como ambientes institucionalmente criados pelo próprio Estado e passíveis de regulação. Se a Constituição tivesse determinado que o próprio Estado realizasse atividade econômica, não haveria mercado para a atividade empresarial privada. Foi a opção constitucional pela não realização de atividade econômica pelo Estado que gerou o âmbito da atuação privada que dá forma aos mercados. Em outras palavras, de uma maneira ou de outra, os mercados são decorrentes de uma maior ou menor 
abertura institucional para o seu funcionamento. Na linha deste argumento, compreende-se que se o próprio Estado cria os mercados, pode regulá-los para buscar concretizar valores e objetivos fundamentais previstos na Constituição, em outros termos, para realizar a fruição de direitos fundamentais pela população.

Identificam-se, assim, os pressupostos metalinguísticos da Constituição Federal com os do Estado Empreendedor. E não poderia ser diferente, porque foi a Constituição que adotou o perfil de Estado Empreendedor ao Estado brasileiro em matéria de CT\&I. Este modelo de Estado exige uma política que não se confunde episodicamente com programas de governos, partidos políticos ou dirigentes específicos, mas que permaneça perenemente na agenda do funcionamento do Estado. Exige a superação de entraves patrimonialistas que ainda marcam o funcionamento da administração pública brasileira e de facções que aprisionam a articulação estatal a interesses privados ao invés de perseguir motivações estratégicas. Foi consagrada no texto constitucional a postura de compromisso com o desenvolvimento econômico e tecnológico nacional mediante a regulação do Estado Empreendedor.

A função regulatória a ser desempenhada pelo Estado Empreendedor abrange diversas medidas que podem ser inseridas como conteúdo de políticas públicas voltadas para o desenvolvimento da inovação tecnológica, cuja extensão não temos aqui a pretensão de esgotar, apenas de sintetizar seus traços mais relevantes:

a) Tomar a consciência de que investimentos em educação, pesquisa e inovação são fundamentais para viabilizar o desenvolvimento nacional. Afasta-se a visão míope de que, em nome de ajustes fiscais e metas de superavit primário, deve-se cortar investimentos em políticas estratégicas que darão suporte ao desenvolvimento nacional;

b) Disponibilizar amplas fontes de financiamentos a pesquisas através de diversos órgãos e entidades governamentais que procurem atender à pequenas e grandes empresas em todas as regiões do país e segmentos da economia, pelo critério do fomento a atividades econômicas novas na economia nacional, regional ou local, com potencial de acesso a novos mercados;

c) Assumir os riscos de pesquisas cujas incertezas de resultados científicos e tecnológicos afastam a iniciativa privada, abrindo fronteiras tecnológicas que gerem novos produtos e mercados; 
d) Criar um sistema nacional de inovação que articule os diversos atores públicos e privados em pesquisa e desenvolvimento $(\mathrm{P} \& \mathrm{D})$, abrangente das três esferas do Estado (Federal, Estadual e Municipal), de empresas e centros públicos e privados de pesquisas, notadamente universidades;

e) Fomentar a interação entre empresas e universidades para a realização de projetos em $\mathrm{P} \& \mathrm{D}$, bem como a formação de parcerias entre os diversos atores em inovação;

f) Promover a internacionalização das empresas e diversos atores em P\&D, com o fim de elevar o grau de conhecimento do país e estabelecer padrões internacionais de seleção de projetos para serem financiados;

g) Prospectar nichos com potencial de criação de novos produtos e constituição de novos mercados, canalizando os investimentos e direcionando o fomento público para estes setores estratégicos;

h) Identificar e definir setores estratégicos para a economia, competitividade, soberania e interesses nacionais em geral que possam ser solucionados mediante novas tecnologias e inovação;

i) Focar na diversificação da economia para que esta não fique concentrada em poucas atividades econômicas, superando, em especial, o fato de nossa balança comercial depender em sua maior parte de produtos agrícolas;

j) Traçar estratégias e políticas públicas correspondentes e mantê-las de forma constante, não episódica, nem limitadas a governos e a partidos políticos, a fim de atingir sólida base tecnológica para o país, no médio e longo prazos;

k) Submeter empresas e demais entidades privadas que recebam financiamento público em P\&D à supervisão pública e a auditorias de performance periódicas;

1) Criar políticas direcionadas para as deficiências de cada setor, especialmente mediante oitiva e interlocução com o setor privado, em âmbito nacional, regional e local;

m) Rejeitar concepções de desenvolvimento centradas apenas no mercado de capitais e que sustentem a eliminação da regulação estatal sobre a economia. O Estado não deve ser mínimo nem máximo, mas ter o tamanho necessário para ser capaz de regular a economia e concretizar direitos fundamentais. Afastam-se, portanto, teorias do desenvolvimento que prescrevem reformas ligadas tão somente à proteção de investidores e acionistas e sustentam o fortalecimento das instituições de mercado como as únicas viáveis (endowment), e deixam de lado reformas 
institucionais que prestigiem características específicas de cada local (embeddeness).

No tocante à política pública e aos demais instrumentos de regulação da ciência, tecnologia e inovação, é importante apontar as conclusões apresentadas por Simone Scholze (2016), no sentido de que falta ao processo político-regulatório brasileiro no referido setor a adoção dos pressupostos das principais teorias regulatórias ${ }^{17}$, fato esse que contribui para a dificuldade em superar gargalos que insistem em permanecer na promoção e incentivo às tecnologias da informação e comunicação no país.

A partir da análise da política de apoio e fomento à pesquisa científica, tecnológica e de inovação realizada segundo a Lei de Informática (Lei no 8.248, de 23 de outubro de 1991), a autora constatou que a adoção das prescrições das novas teorias regulatórias poderia aperfeiçoar a atuação do Estado brasileiro, em especial em sua relação com a indústria, e que a conduta estatal carente dos pressupostos de tais teorias resulta em atividade regulatória muitas vezes incapaz de superar os problemas que impedem o desenvolvimento tecnológico sustentável do país.

O Estado, segundo Simone Scholze (2016), deve principalmente se modernizar para realizar interlocução com os atores dos setores regulados, concretizando abertura democrática que renove a interface da relação governo/indústria, notadamente em razão de, no mundo contemporâneo, ser necessária a definição dos papéis que cabem aos atores envolvidos em cada setor regulado, dado que a atuação estanque entre tais indivíduos elimina a possibilidade de sinergias essenciais para a inovação e os empreendimentos econômicos. Daí o foco especial dado pela autora à teoria da regulação responsiva, de Braithwaite, que propõe mecanismos de atuação consensual entre as partes para solução das questões surgidas, ao invés dos tradicionais instrumentos de regulação sancionatória. Considera, com isso, que a teoria da regulação responsiva e as demais teorias regulatórias apontadas poderão oferecer aportes significativos para a construção de um modelo definido de atuação do Estado brasileiro nas políticas públicas de promoção ao desenvolvimento tecnológico.

\footnotetext{
${ }^{17}$ Dentre as teorias apontadas pela autora, estão entre as principais: a Teoria da Regulação de Interesse Público, de Steven Croley; a Teoria da Modernização Reflexiva, proposta por Ulrich Beck e Anthony Giddens; a Teoria Social da Regulação, de Cass Sunstein; a Teoria do Estado Regulador, desenvolvida por Carlos A. Sundfeld, Floriano Marques, Márcio Iorio Aranha, Alexandre Aragão, Marçal Justen Filho; Teoria do Estado Empreendedor, de Mariana Mazzucato; Teoria da Regulação Responsiva, de Braithwaite.
} 


\section{1 - Estado Empreendedor e capitalismo de Estado}

Identificados os pressupostos conceituais do Estado Empreendedor na Constituição Federal, é necessário precisar seu conceito face ao capitalismo de Estado, a fim de evitar confusões sobre o papel que desempenha na economia.

A necessidade de afastar esse tipo de confusão conceitual surge a partir do próprio qualificativo "empreendedor". Empreender significa realizar, fazer alguma atividade, designando, em economia, a realização de atividade econômica. O "Estado Empreendedor”, à primeira vista, poderia levar a crer que cabe ao Estado a realização de atividade econômica diretamente, ou seja, seria o Estado empresário, que reuniria os fatores de produção necessários e exploraria atividade econômica. Contudo, vimos que na Constituição Federal do Brasil somente em situações excepcionais o Estado realiza atividade econômica, e que seu papel é o de regulador da economia para a garantia de direitos fundamentais.

O empreendedorismo do "Estado Empreendedor" é no sentido de regular (moldar e conduzir) a economia para orientá-la ao desenvolvimento, mas de modo que, em primeiro lugar, a atividade econômica seja realizada pelo setor privado. Esse papel se faz por meio da sua atividade regulatória (gerenciamento permanente da realidade através de diversos mecanismos jurídicos para orientar a economia ao desenvolvimento). No campo da regulação da CT\&I, o empreendedorismo é no sentido do desbravamento de novos mercados através da inovação tecnológica. Em suma, Estado Empreendedor não é aquele que tem por missão realizar atividade econômica, mas sim regular o setor de CT\&I para estimular o desenvolvimento econômico, lançando mão de diversos mecanismos jurídicos para viabilizar esse objetivo.

Afasta-se, portanto, a visão de que o Estado Empreendedor se confunde com capitalismo de Estado, em especial a modalidade de capitalismo de Estado que marcou o século $20^{18}$. Conforme veremos, o século 21 tem conhecido novas modalidades de capitalismo de Estado com as quais o Estado Empreendedor se relaciona, encontrando nelas canais de realização de suas políticas industriais.

\footnotetext{
${ }^{18}$ Neste tópico, não se tem a pretensão de explorar toda a conceituação de Capitalismo de Estado, tema que foi abordado por diversas correntes políticas e econômicas, socialistas e liberais, angariando grande conteúdo teórico e semântico ao longo do tempo. Pretendemos apenas realçar o fato de que Estado Empreendedor não se confunde com Capitalismo de Estado, embora em certas situações recorra às novas formas de Estado como empresário para alcançar seus objetivos regulatórios, como será apontado.
} 
Por capitalismo de Estado nos referimos à exploração de atividade econômica diretamente pelo Estado, em que este é o proprietário dos meios de produção e realizador da atividade econômica através de empresas que fazem parte de sua estrutura institucional. Musacchio e Lazzarini (2015) definem capitalismo de Estado como aquele em que "os governos são proprietários e gestores de empresas estatais (SOES), como extensões da burocracia pública". Em outras palavras, o capitalismo é o sistema econômico em que os meios de produção (recursos disponíveis para a realização da atividade econômica) são privados, ou seja, não são coletivos, pertencem a um ou mais proprietários definidos que podem usar, gozar e dispor desses meios para a realização de atividade econômica. No capitalismo de Estado, o proprietário dos meios de produção é o Estado, que realiza a atividade econômica.

O capitalismo de Estado teve papel importante no século 20, quando os Estados nacionais passaram a explorar atividade econômica diretamente através de empresas pertencentes às suas estruturas administrativas. No Brasil especialmente, o capitalismo de Estado foi responsável pela industrialização do país, tendo ocorrido um aumento vertiginoso de empresas estatais na segunda metade do século passado (BRUM, 1998).

De fato, conforme amplamente abordado acima, o Estado Empreendedor no Brasil não explora atividade econômica, somente excepcionalmente, segundo a Constituição Federal. Para Mazzucato (2014), embora ao Estado Empreendedor caiba a função de financiar o desenvolvimento tecnológico, deve deixar a exploração direta de atividade econômica ao setor privado.

Por outro lado, segundo demonstram Musacchio e Lazzarini (2015), novas formas de capitalismo de Estado têm surgido desde o fim do século 20, intensificando-se a partir dos anos 2000. São modalidades marcadas pelo fato de o Estado não ter mais a totalidade da propriedade de empresas, mas por atuar como acionista majoritário ou minoritário em empresas nas quais outrora fora proprietário integral, ou em empresas que nasceram privadas e das quais o Estado comprou participações acionárias, geralmente através de empresas estatais, holdings ou fundos de pensão.

Essas novas modalidades de capitalismo de Estado - como acionista majoritário ou acionista minoritário - surgiram como consequência da crise pela qual passou o modelo do Estado empresário a partir da década de 1970. Musacchio e Lazzarini (2015) apontam que nas últimas décadas do século passado as empresas estatais passaram por graves dificuldades econômicas notadamente após a crise do petróleo, especialmente nos países em 
desenvolvimento como o Brasil. Os governos sempre socorreram as empresas deficitárias, mantidas mesmo ao custo de prejuízos porque acabavam sendo utilizadas como instrumentos para perseguir objetivos sociais, por exemplo a manutenção da atividade empresarial em regiões não atrativas para ofertar bens e serviços aos consumidores. Além disso, em momentos de crise, as empresas estatais não adotavam as mesmas medidas encontradas no setor privado, como demissão de empregados, tendo em vista que os governos não queriam contribuir para o aumento do desemprego. Ademais, com a quebra da confiabilidade de países em desenvolvimento nas últimas décadas do século passado, em razão da escassez de liquidez no cenário pós-crise do petróleo (anos 1970), as empresas estatais passaram a ser usadas para captação de recursos internacionais a fim de promover a entrada de dólares no país, aumentando seus prejuízos. No Brasil, afirmam Musacchio e Lazzarini (2015), essas práticas foram adotadas na gestão de empresas estatais. Esses e outros fatores contribuíram para que tais empresas passassem a ser um peso excessivo para os governos, aumentando o deficit público, o que implicou numa onda de privatizações e reformas de governança nas estatais para adoção de práticas típicas da gestão privada, como novas regras de transparência.

Em meio à onda de privatizações das estatais, o capitalismo de Estado foi ganhando novas feições. A abertura do capital dessas empresas foi um dos meios de transformação de suas estruturas para ganhos de eficiência e lucratividade. Houve casos em que as regras de governança foram reestruturadas para proteção dos acionistas minoritários, passando a coexistir capital público e privado numa mesma empresa. Em outras situações, o Estado passou a ser acionista minoritário de empresas privatizadas, às vezes como forma de atenuar as críticas contra a privatização do patrimônio público. O fato é que, como afirmam Musacchio e Lazzarini (2015), o Estado paulatinamente passou de capitalista que atua como proprietário da totalidade do empreendimento para dividir com o setor privado a realização da atividade empresarial, ora como acionista majoritário, ora minoritário.

A manutenção da titularidade majoritária de ações confere ao Estado a possibilidade de controle de empresas consideradas estratégicas, em setores como petróleo e gás natural (Petrobras, por exemplo), ao tempo em que permite a restruturação das empresas pela entrada de investidores privados. A adoção de novas regras de governança e a necessidade de atender aos interesses de novos acionistas, preocupados com o lucro ao invés de objetivos sociais, atenuou (mas não eliminou) intervenções dos governos na gestão das empresas, uma das causas da crise do século passado. Já a participação minoritária do Estado em empresas privatizadas, ou até mesmo em empresas que sempre foram privadas (Estado 
como acionista minoritário), passou a ser utilizada como instrumento de política industrial, para injeção de capital em empresas de setores considerados importantes e carentes de impulso, suprindo a falta de um mercado de capitais mais robusto no país. No setor de ciência, tecnologia e inovação, o Banco Nacional de Desenvolvimento Econômico e Social (BNDES) tem realizado a injeção de capital mediante compra de participações em empresas iniciantes, como forma de alavancar pesquisa e desenvolvimento no país. Trata-se, mais especificamente, da atuação do BNDES como investidor em venture capital (capital de risco). O venture capital, segundo Schapiro (2012), é o investimento em empresas iniciantes com potencial de desenvolvimento, mediante aporte de recursos para financiamento da atividade empresarial que se inicia, com o objetivo de retirada dos investimentos com lucro, no futuro, quando da maturação da empresa.

Schapiro (2012) demonstra que o BNDES tem se valido do venture capital em sua política de desenvolvimento da inovação, mediante a realização de aportes de recursos em empresas iniciantes com potencial de sucesso em setores estratégicos (start ups) para fomento de suas atividades e contribuição ao desenvolvimento da ciência, tecnologia e inovação nacionais. Paralelamente à sua atuação com “capitalista de risco", o BNDES tem contribuído para a criação do mercado nacional de venture capital, a fim de que o setor privado exerça a função de investir em empresas iniciantes com potencial de inovação (SCHAPIRO, 2012). Essa contribuição tem se dado principalmente mediante a formação de fundos privados de capital de risco, nos quais o BNDES aporta recursos para atrair capitais privados que aumentem o volume desses fundos e, consequentemente, dos recursos a serem empregados em venture capital voltado à inovação. Aqui, percebe-se a tentativa de constituição do mercado de venture capital no país através da atuação do BNDES, visando à consolidação desse mercado para o contínuo estímulo à inovação mediante capital privado. A criação desse mercado através do protagonismo do Estado, com atuação de um banco público de desenvolvimento, coaduna-se com o pressuposto conceitual do Estado Empreendedor segundo o qual lhe cabe a constituição de novos mercados para o desenvolvimento nacional. Adequa-se também ao pressuposto conceitual de formação de parcerias público-privadas em inovação científica e tecnológica. No caso, através do venture capital, formam-se parcerias entre o ente público (BNDES) que aporta recursos e a empresa privada que realiza atividade econômica e produz inovações. Sobre essa experiência, Lessa Mattos (2009) afirma que a atuação do BNDES caracteriza compartilhamento dos riscos entre Estado e empresas inovadoras emergentes para fomento da inovação nacional. 
Todo esse contexto demonstra que novas formas de capitalismo de Estado entram em sintonia com as políticas do Estado Empreendedor. Embora este não signifique o capitalismo de Estado como visto no século 20, afina-se com outras formas de capitalismo por meio das quais as políticas industriais e de desenvolvimento poderão ser realizadas. Assim, fica esclarecido que o Estado Empreendedor, apesar de não ter por função a exploração de atividade econômica de acordo com o modelo constitucional brasileiro, poderá valer-se de outras modalidades de capitalismo de Estado surgidas com o século 21, sem que tal fenômeno viole a Constituição Federal, como demonstram as experiências do BNDES em venture capital voltado a empresas emergentes inovadoras.

\section{2 - Estado Empreendedor e sustentabilidade}

A análise do texto constitucional de forma sistemática revela ainda outro pressuposto a ser levado em consideração em relação à ciência, tecnologia e inovação, segundo o papel que desempenham a partir das premissas constitucionais adotadas. Trata-se da sustentabilidade, objetivo a ser alcançado pelo Estado Empreendedor e para o qual a inovação tecnológica passa a ser instrumento essencial, tendo em vista sua função de solucionar problemas nacionais e promover o desenvolvimento econômico. A partir da investigação do conteúdo normativo do texto constitucional, em especial dos objetivos fundamentais da República, chega-se à conclusão de que o Estado Empreendedor deve ser sustentável.

O ponto de partida é a premissa segundo a qual, no sistema constitucional brasileiro, desenvolvimento não é outro senão o desenvolvimento sustentável. Trata-se de princípio com inequívoco assento constitucional que espalha sua influência em todo o sistema jurídico, notadamente na construção de novo papel que o Estado Regulador deve assumir, inclusive na dimensão que o caracteriza como Estado Empreendedor.

Por desenvolvimento sustentável, ou sustentabilidade, entende-se o princípio constitucional segundo o qual devem ser assegurados (concretizados) os direitos fundamentais para realização do bem-estar das gerações presentes, sem comprometer estes mesmos direitos e o bem-estar para as gerações futuras (FREITAS, 2012).

A Constituição brasileira, desde seu preâmbulo, deixa claro que tem por objetivo fundamental assegurar o desenvolvimento. Note-se que a Constituição fala em 
desenvolvimento com termo genérico, sem limitação provocada por qualquer adjetivo, para denotar o desenvolvimento em todos os sentidos possíveis, a fim de viabilizar todas as potencialidades individuais e coletivas do ser humano. Além do mais, o termo desenvolvimento, no preâmbulo constitucional, assim como em toda a extensão do texto constitucional, deve ser compreendido conjuntamente aos demais objetivos, ligado aos direitos individuais e sociais, ao bem-estar, à segurança, à liberdade, ao pluralismo e a todos os valores assumidos pela Carta Constitucional. Este desenvolvimento só pode ser concebido como sustentável, ou seja, que se mantém, se sustenta, não é episódico, é duradouro, viabilizador dos direitos fundamentais, todos eles, para as gerações presentes e futuras. Em outras palavras, não é o desenvolvimento que favorece apenas o presente, ou o limite temporal de um governo, ou aquele que compromete os direitos fundamentais das gerações futuras, mas o que se realiza no presente com pensamento também no futuro, prospectivamente. E para que assim o seja, o desenvolvimento sustentável tem que articular os âmbitos econômico, social e ambiental, dado que a dignidade humana somente é viabilizada quando realizada por completo.

Após o preâmbulo, e já entrando nos enunciados constitucionais, o art. 3o, II arrola como objetivo fundamental da República Federativa do Brasil garantir o desenvolvimento nacional. Aqui também o desenvolvimento não pode ser outro senão o sustentável, sendo esta a compreensão que se harmoniza com a essência de uma Constituição democrática. A Constituição Federal tem um plano para a nação, visando colocar o país num patamar de realização de direitos fundamentais que hoje não é assegurado a todos os brasileiros. A Constituição veicula valores, faz determinações, acrescenta objetivos, prescreve fundamentos e impõe a concretização de direitos para dirigir os rumos de Estado, governo e sociedade com o escopo maior de reconstruir o país sob a égide dos direitos fundamentais. Todo este plano constitucional somente tem razão de ser se o novo patamar de país for sustentável, se as conquistas perdurarem, ao invés de desmoronarem em pouco tempo em razão do comportamento político errático, de crises econômicas desestabilizadoras e de padrões de consumo devastadores da sociedade e do Estado que comprometam o bem-estar das gerações futuras. Em outras palavras, para realizar os demais objetivos fundamentais da República, o desenvolvimento nacional tem que ser sustentável, dado que somente com políticas duradouras e com olhar no futuro se pode construir uma sociedade livre, justa e solidária, erradicar a pobreza e a marginalização, reduzir as desigualdades sociais e regionais e promover o bem de todos sem qualquer forma de preconceito. Tais objetivos não se 
alcançam de um dia para o outro, nem no limite temporal de um governo ou mandato político, mas na implementação persistente e duradoura de políticas de Estado, como cumprimento das determinações constitucionais, até que, com avanços progressivos, a fruição de direitos fundamentais por todos passa a ser realidade.

A sustentabilidade (ou desenvolvimento nacional sustentável) também tem o viés da economia de recursos materiais para permitir sua renovação, no sentido ambiental da compreensão, ou seja, de consumo racional dos recursos da natureza na intensidade e velocidade que permitam sua regeneração e consequente permanência, para viabilizar sua fruição material e imaterial pelas gerações futuras. Realmente, os recursos da natureza estão umbilicalmente ligados a diversos direitos fundamentais, de maneira que a extração e o consumo sustentável se impõem para a preservação do bem-estar das gerações futuras. Aqui a sustentabilidade está diretamente relacionada a direitos de produção e de consumo, ligada à forma como a economia é realizada, ao modo de produção de bens e serviços e ao padrão social de consumo e descarte destes bens e serviços. Esta dimensão da sustentabilidade não foi deixada de fora das prescrições constitucionais. O art. 170, VI, do texto constitucional é claro ao determinar que a ordem econômica tem como princípio a defesa do meio ambiente. A atividade econômica não pode ser realizada de forma que seja destruído o meio ambiente. A economia deve produzir de maneira sustentável, ou seja, sem extinguir os recursos da natureza, de modo a permitir sua regeneração, permanência, para que não se esgotem e inviabilizem o bem-estar das gerações futuras. E para completar o firme compromisso da Constituição Federal do Brasil com a sustentabilidade, o art. 225 prescreve diretamente o direito de todos ao meio ambiente sadio e equilibrado, para preservação dos direitos das gerações presentes e futuras, sendo dever do Estado e da sociedade defendê-lo.

Os arts. 3ㅜ, II, 170, VI, e 225, caput, da Constituição Federal autorizam, sem qualquer sombra de dúvida, a compreensão do desenvolvimento nacional como sendo somente o sustentável. Este, por sua vez, deverá ser multidimensional (ou pluridimensional) (FREITAS, 2012), o que significa que o desenvolvimento nacional sustentável abrange todas as áreas possíveis da vida, por imposição direta da dignidade humana, que não pode ser realizada de forma fracionada, mas somente em plenitude. Com efeito, não se pode falar em vida digna se apenas uma ou outra dimensão da vida humana tem direitos fundamentais assegurados. Seria absurdo falar de vida digna a quem, embora livre para ir e vir, não tem emprego digno, moradia salubre, assistência à saúde, direito à educação de qualidade. A dignidade humana não aceita fragmentação. Tem que ser plena. Assim se passa com a 
sustentabilidade. Se esta fosse apenas unidimensional, ou bidimensional, seria insuficiente, dada a ausência de fundamentos imprescindíveis. Tem que ser pluridimensional, abrangendo todas as áreas da vida, em especial a econômica, a social e a ambiental ${ }^{19}$.

Em sua dimensão econômica, a sustentabilidade significa, primeiramente, uma nova economia, cujo modo de produção seja racional ao ponto de não consumir os recursos naturais e esgotá-los para as gerações futuras. Significa mudar as relações em torno das atividades de produção e consumo para adotar práticas sustentáveis, na qual as consequências positivas e negativas dos processos adotados sejam ponderadas, a fim de estabelecer padrões racionais de produção e consumo, negando a reificação do ser humano diante das coisas, o consumo como fim em si mesmo, o lucro como medida de tudo. A dimensão econômica da sustentabilidade também significa a regulação racional da economia para evitar a ditadura dos mercados típica do mundo globalizado contemporâneo, para que o comando seja dos direitos fundamentais, submetendo a economia aos princípios da Constituição Federal. A dimensão econômica da sustentabilidade significa ainda a geração de riqueza de forma estável e equilibrada, capaz de manter um padrão de bem-estar e fruição de direitos fundamentais por todos, inclusivamente, o que pressupõe uma economia mais competitiva no mercado global, com inserção em mercados de produtos mais sofisticados, capaz de manter melhores salários, empregos, distribuição de riqueza de forma permanente e não oscilante.

A dimensão social da sustentabilidade significa assegurar a todos, indistintamente, direitos sociais, culturais e econômicos. Trata-se do fim da marginalização social, da erradicação da pobreza e da eliminação das desigualdades, para lembrar aqui os objetivos fundamentais da República Federativa do Brasil. Com efeito, de nada adianta o desenvolvimento se ele não for para todos. Todo cidadão tem que ter acesso livre e pleno ao trabalho, à educação, saúde, alimentação, moradia, bens e serviços, e todos os demais elementos materiais indispensáveis à vida. O desenvolvimento só é sustentável se assegurar a todos, permanentemente, o acesso a este conjunto de direitos sociais, econômicos e culturais, aptos a realizar o estado de bem-estar para as gerações presentes e futuras. São direitos sem os quais o ser humano não consegue realizar suas potencialidades em plenitude. Tal reviravolta

\footnotetext{
${ }^{19}$ Juarez Freitas (2012) sustenta que além das dimensões ambiental, econômica e social, a sustentabilidade tem ainda a dimensão ética e a jurídico-política. A primeira, segundo o autor, significa a adoção da "solidariedade como dever universal de deixar o legado positivo na face da terra (...)", "com o pleno reconhecimento da dignidade intrínseca dos seres vivos em geral” (p. 60-63). A dimensão jurídico-política consiste na "tutela jurídica do direito ao futuro e, assim, apresenta-se como dever constitucional de proteger a liberdade de cada cidadão (titular de cidadania ambiental ou ecológica), nesse status, no processo de estipulação intersubjetiva do conteúdo intertemporal dos direitos e deveres fundamentais das gerações presentes e futuras, sempre que viável diretamente" (p. 67).
} 
na realidade exige que o desenvolvimento condicione a economia ao humano, não o oposto, como se constata no mundo contemporâneo.

Por sua vez, a dimensão ambiental da sustentabilidade está ligada à relação do ser humano com a natureza e os demais seres vivos, à preservação de ambientes naturais e urbanos sadios. O comportamento humano em relação ao meio ambiente deve mudar para que a extração e o uso dos recursos naturais sejam de forma a não os esgotar, permitindo sua renovação para que haja continuidade para as gerações futuras. A ocupação de espaços naturais pelos seres humanos deve buscar o equilíbrio com os ecossistemas, para que não sejam extintos e destruídos. As externalidades do consumo e empreendimentos humanos (lixo industrial e doméstico) devem ter destinação adequada, ser recicladas para evitar a contaminação do solo, das águas e dos ambientes naturais. A poluição do ar e das águas deve ser controlada e alternativas limpas adotadas, evitando a contaminação dos recursos hídricos escassos e a poluição atmosférica que gera o aquecimento global. Fontes de energias limpas devem ser adotadas, com a abolição dos combustíveis fósseis que aceleram a degradação ambiental. Energias solar, eólica e hidroelétrica devem ser as alternativas principais.

Diante de tudo o que se colocou acima sobre a sustentabilidade, pergunta-se: qual o papel do Estado Empreendedor em relação à sustentabilidade? Qual o papel que ciência, tecnologia e inovação possuem em relação ao desenvolvimento sustentável?

Como vimos, a Constituição Federal prescreve que a pesquisa básica buscará o bem público (art. 218, §1ํ) e a pesquisa tecnológica voltar-se-á para a solução dos problemas brasileiros e para o desenvolvimento do sistema produtivo nacional e regional (art. 218, §2º). Por sua vez, o mercado interno integra o patrimônio nacional e será incentivado para viabilizar o desenvolvimento cultural e socioeconômico, o bem-estar da população e a autonomia tecnológica do país (art. 219). Embora o desenvolvimento mencionado no capítulo da Constituição sobre ciência, tecnologia e inovação tenha os adjetivos "cultural" e "socioeconômico", ambos em nada limitam o fato de que este desenvolvimento deve ser sustentável numa perspectiva pluridimensional, dado que o texto constitucional é um só, e como um sistema deve ser interpretado. Portanto, logicamente, o conceito de desenvolvimento aqui apontado é o de desenvolvimento sustentável pleno. Ciência, tecnologia e inovação são, neste contexto, concebidas nas disposições constitucionais como instrumentos a serviço do desenvolvimento nacional sustentável. Exemplos concretos de como ciência, tecnologia e inovação contribuem para todas as dimensões da sustentabilidade são vistos na saúde pública, com novos medicamentos e vacinas produzidos para a melhoria 
das condições de vida (dimensão social); novos materiais podem ser desenvolvidos para a construção de moradias com custo menor, reduzindo o deficit habitacional e empregando recursos menos invasivos ao meio ambiente (dimensões social e ambiental); novos produtos e serviços podem ser desenvolvidos, proporcionando maior competitividade das empresas brasileiras no comércio mundial, levando ao crescimento econômico nacional sustentável, aumentando exportações e a tributação que ajusta as contas públicas (dimensão econômica); processos de produção menos invasivos e sustentáveis podem ser criados para preservar o meio ambiente (dimensão ambiental); práticas inovadoras e sustentáveis de extração dos recursos naturais (dimensão ambiental); agricultura mais eficiente, com preservação dos solos, menos agrotóxicos, maior segurança alimentar da população e aumento nas exportações de produtos primários (dimensões social, ambiental e econômica); incremento em fontes limpas e renováveis de energia, como a eólica, a hidroelétrica, a biomassa e a solar, com pesquisas que criem formas viáveis de utilização destas alternativas energéticas em larga escala, especialmente a solar, em cada casa, em cada prédio público, cabendo aqui a forte atuação do Estado no fomento a tais alternativas energéticas mediante incentivos, especialmente tributários (dimensões ambiental e econômica). Como se pode constatar, ciência, tecnologia e inovação podem gerar novos instrumentos e tornar possíveis estratégias de realização da sustentabilidade. É este o papel que a Constituição lhes reserva no objetivo de realizar a desenvolvimento nacional sustentável.

O Estado Empreendedor, por ser a dimensão do Estado Regulador no setor de CT\&I, tem a missão de conduzir e dirigir o desenvolvimento de novas tecnologias que promovam o desenvolvimento nacional sustentável, seja na esfera ambiental, com a introdução de fontes renováveis de energia, na econômica, com a abertura de novos mercados através da inovação, e na social, solucionando por meios tecnológicos problemas da sociedade para lhe proporcionar bem-estar. No processo de regulação do setor de CT\&I, o Estado Empreendedor deverá levar em consideração o princípio constitucional da sustentabilidade para orientar suas decisões políticas sobre quais pesquisas financiar e com que objetivo. Deverá investir em áreas de incerteza (que afastam o capital privado) para gerar conhecimento que abrirá novos mercados ao país, visando produzir riqueza de forma sustentável. O mercado das energias limpas - solar e eólica, em especial - talvez seja o exemplo mais claro desse papel. O Estado Empreendedor brasileiro tem uma larga fronteira tecnológica a explorar neste setor, em todas as dimensões da sustentabilidade aqui abordadas. $\mathrm{O}$ investimento em pesquisa e inovação em energias renováveis pode ampliar a inserção do país no mercado mundial que 
cresce a cada ano, contribuindo para o aumento da riqueza nacional e da balança comercial favorável (dimensão econômica). Simultaneamente, confere segurança energética ao Brasil que é farto em luz solar e possui regiões com abundância de ventos, sem prejudicar o meio ambiente dado o caráter renovável destas fontes (dimensão ambiental). Paralelamente, por consequência do desenvolvimento nas dimensões econômica e ambiental, socialmente se alcança melhores patamares pela maior circulação de riqueza no país, o acesso mais fácil e barato à energia elétrica, o menor gasto público com energia e a segurança da infraestrutura energética que é base indispensável para a fruição de diversos direitos fundamentais.

Em setembro de 2015, a Assembleia Geral das Nações Unidas se reuniu e produziu a Declaração sobre os Novos Objetivos de Desenvolvimento Sustentável (ONU, 2015), como meta até 2030. Dentre os 17 (dezessete) objetivos estabelecidos, nos quais a inovação tecnológica desempenha papel fundamental, dado o potencial de criar soluções para diversas demandas, os Objetivos 8 e $9^{20}$ estão direta e explicitamente ligados ao desenvolvimento de novas tecnologias. Em outros termos, na linha do que estamos sustentando, a Organização das Nações Unidas considera que inovação e desenvolvimento tecnológico são instrumentos para promoção do desenvolvimento sustentável em todas as suas dimensões ${ }^{21}$.

Por sua vez, a Lei no 10.973, de 2 de dezembro de 2004 (Lei de Inovação), após as alterações realizadas pela Lei no 13.243, de 11 de janeiro de 2016, define inovação como:

Introdução de novidade ou aperfeiçoamento no ambiente produtivo e social que resulte em novos produtos, serviços ou processos ou que compreenda a agregação de novas funcionalidades ou características a produto, serviço ou processo já existente que possa resultar em melhorias e em efetivo ganho de qualidade ou desempenho

Observe-se que a referida lei menciona expressamente o ambiente "social", deixando claro que as inovações não se limitam ao setor produtivo (dimensão econômica), mas também deverão se voltar para a solução dos problemas sociais do país, na esteira da multidimensionalidade da sustentabilidade. Evidentemente, a lei poderia ter ido além e

\footnotetext{
${ }^{20}$ Objetivo 8: Promover o crescimento econômico sustentado, inclusivo e sustentável, emprego pleno e produtivo e trabalho decente para todos. (...) 8.2 Atingir níveis mais elevados de produtividade das economias por meio da diversificação, modernização tecnológica e inovação, inclusive por meio de um foco em setores de alto valor agregado e dos setores intensivos em mão de obra. (...) Objetivo 9: Construir infraestruturas resilientes, promover a industrialização inclusiva e sustentável e fomentar a inovação. (...) 9.5 Fortalecer a pesquisa científica, melhorar as capacidades tecnológicas de setor es industriais em todos os países, particularmente os países em desenvolvimento, inclusive, até 2030, incentivando a inovação e aumentando substancialmente o número de trabalhadores de pesquisa e desenvolvimento por milhão de pessoas e os gastos público e privado em pesquisa e desenvolvimento. (...).
}

${ }^{21}$ A Declaração sobre os Novos Objetivos de Desenvolvimento Sustentável (ONU, 2015) menciona três dimensões da sustentabilidade: a ambiental, a econômica e a social. 
abrangido a dimensão ambiental no conceito de inovação. Esta falta, contudo, não prejudica em nada o aspecto multidimensional da inovação, dado que no sistema constitucional brasileiro é patente a dimensão ambiental na sustentabilidade.

Por tudo isso, o Estado Empreendedor deve ser também sustentável. Se

retornarmos ao conceito de Estado Empreendedor acima apresentado, deveremos inserir a sustentabilidade para que sua configuração seja plena.

Assim o fazendo, Estado Empreendedor, na definição sintética, é aquele que regula (conduz e molda) o setor de ciência, tecnologia e inovação visando à efetivação de direitos fundamentais de forma sustentável.

No conceito mais amplo, Estado Empreendedor é aquele que regula o setor de ciência, tecnologia e inovação para a criação de tecnologias que gerem soluções diversas para o país em termos de efetivação de direitos fundamentais, direitos de produção em destaque, em especial a criação de novos produtos e processos para abertura de mercados e ganhos de competitividade, mediante a assunção de riscos de financiamento de longo prazo a pesquisas cujas incertezas afastam a iniciativa privada, com ênfase em parcerias público-privadas, visando ao desenvolvimento nacional sustentável.

\section{3 - Conclusão do capítulo}

Demonstrado que a Constituição Federal do Brasil contém os pressupostos conceituais do Estado Empreendedor, ou seja, que foi adotado este modelo de Estado para a regulação do setor de ciência, tecnologia e inovação no país, cabe agora voltar a atenção ao direito infraconstitucional, com o escopo de investigar a repercussão das normas constitucionais no direito positivo brasileiro, em especial sobre as normas que regulam as parcerias entre atores públicos e privados em pesquisa e desenvolvimento científico e tecnológico, considerando que tais relações concretizam um dos pressupostos conceituais do Estado Empreendedor e são essenciais para o desenvolvimento do ecossistema de inovação nacional. 


\section{CAPÍTULO 3 - O ECOSSISTEMA DE INOVAÇÃO E O REGIME JURÍDICO- ADMINISTRATIVO DAS PARCERIAS PÚBLICO-PRIVADAS EM CIÊNCIA, TECNOLOGIA E INOVAÇÃO}

Nos capítulos anteriores, foi demonstrada a importância do Estado Empreendedor para o desenvolvimento econômico sustentável através de inovações em produtos, serviços e processos, notadamente mediante financiamento de pesquisas cujo capital de risco afasta o setor privado, e que a Constituição Federal brasileira adotou o modelo do Estado Empreendedor para a ciência, tecnologia e inovação nacionais.

Um dos pressupostos conceituais do Estado Empreendedor, como vimos, é a parceria público-privada ${ }^{22}$ para o desenvolvimento de inovações, segundo o qual, a interação entre o setor público (Estado) e o privado (empresas e sociedade civil organizada) é fundamental para implementar pesquisa e desenvolvimento tecnológico. Isso porque, de um lado, cabe ao setor privado (empresas) realizar a atividade econômica geradora de riqueza, e do outro, ao Estado estimular e regular a produção econômica nacional, sendo que, no âmbito da ciência, tecnologia e inovação, cabe ao ator público primordialmente investir quando riscos e incertezas afastam o capital privado. Cumpre, a partir de agora, aprofundar esse pressuposto conceitual do Estado Empreendedor, porque ele é elemento estruturante do ecossistema de inovação.

Quando se fala em desenvolvimento através de inovações tecnológicas, quase sempre é mencionada a necessidade de fortalecer o ecossistema de inovação nacional (FUERLINGER, FANDL e FUNKE, 2015; MAZZUCATO, 2014). Ecossistema de inovação é o ambiente no qual diversos atores públicos e privados envolvidos no processo de pesquisa científica e tecnológica interagem entre si, intercambiando conhecimentos, ideias, financiamentos, material humano e físico, erros e acertos, influenciando-se reciprocamente e realizando pesquisas e empreendimentos em conjunto. A noção de ecossistema vem da biologia, no qual os diversos seres que compõem um ecossistema interagem entre si até gerar um ambiente autossustentável. A ideia é perfeita para um ambiente que pretende ser fecundo em inovações, porque estas surgirão com mais facilidade e com maior consistência onde os diversos atores envolvidos se alimentam dos conteúdos e experiências uns dos outros e

\footnotetext{
22 Assim como fizemos na Introdução deste trabalho, é importante deixar claro que ao mencionarmos "parcerias públicoprivadas" estaremos usando a expressão em sentido genérico, fazendo referência a qualquer espécie de relação ou negócio jurídico público-privado, sem significar especificamente as parcerias público-privadas previstas na Lei no 11.079 , de 30 de dezembro de 2004, como usualmente são conhecidas as parcerias público-privadas no Brasil.
} 
somam forças em empreendimentos conjuntos. Há inúmeros ecossistemas de inovação no mundo, locais, regionais ou nacionais. O Vale do Silício, na Califórnia, por exemplo, é um notável ecossistema desse tipo porque lá foi constituído um grande celeiro de inovações, onde surgiram empresas inovadoras como Apple e Google.

Nesse cenário, percebe-se que, para trilhar o caminho do desenvolvimento baseado em inovações tecnológicas, será preciso construir e fortalecer o ecossistema de inovação nacional. Fuerlinger, Fandl e Funke (2015) afirmam ser necessária a interação entre governo (Estado), empresas, sociedade civil organizada e universidades (academia) para o desenvolvimento de inovações. Em geral, os atores componentes de um ecossistema de inovação podem ser classificados numa dessas quatro categorias.

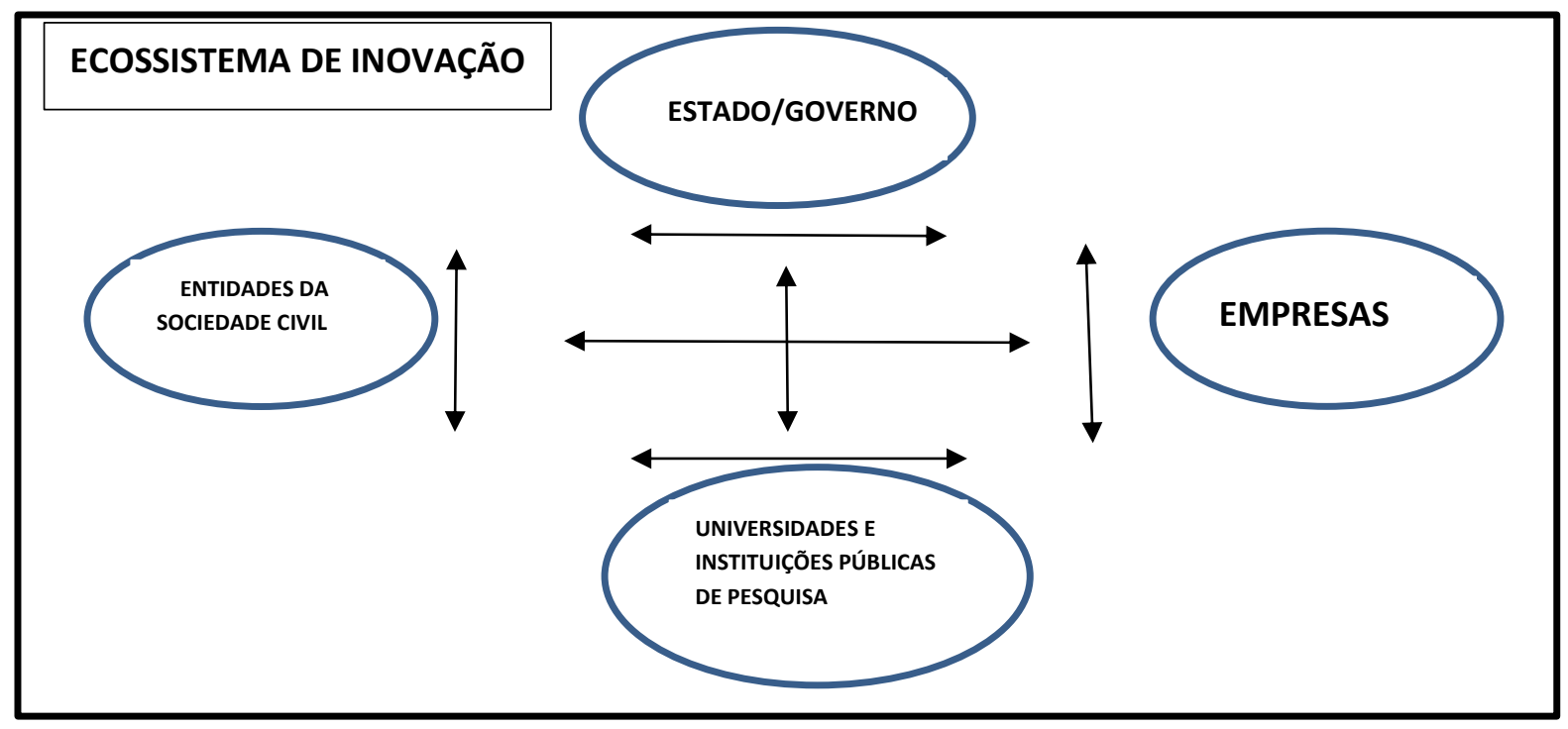

Toda classificação é arbitrária e visa ressaltar aspectos que interessam a quem a elabora. No caso, entendemos que essas quatro categorias bem elucidam a composição de um ecossistema de inovação como o do Brasil. Por certo, determinados atores poderiam ser inseridos em mais de uma categoria, como, por exemplo, uma universidade pública, que é também uma entidade do Estado. É possível que atores ou instituições de mais de uma categoria possam ser enquadrados num mesmo conceito legal relacionado à inovação, como o conceito de Instituição Científica, Tecnológica e de Inovação - ICT $^{23}$. Ou ainda, é possível que atores de classificações distintas desempenhem a mesma função, como uma entidade

\footnotetext{
${ }^{23}$ Nos termos do art. 2o- inciso V, da Lei no 10.973 , de 02 de dezembro de 2004, Instituição Científica, Tecnológica e de Inovação (ICT) é "órgão ou entidade da administração pública direta ou indireta ou pessoa jurídica de direito privado sem fins lucrativos legalmente constituída sob as leis brasileiras, com sede e foro no País, que inclua em sua missão institucion al ou em seu objetivo social ou estatutário a pesquisa básica ou aplicada de caráter científico ou tecnológico ou o desenvolvimento de novos produtos, serviços ou processos".
} 
governamental e uma empresa que financiem pesquisas desenvolvidas numa entidade da sociedade civil. De todo modo, pretendemos ressaltar esses quatro atores do ecossistema de inovação para fornecer uma imagem da qual partir na reflexão sobre as questões envolvidas.

No desenho acima adotado para visualização do ecossistema de inovação aplicável ao Brasil, ${ }^{24}$ pretendemos realçar os atores que podem celebrar negócios jurídicos para formar parcerias em empreendimentos de pesquisa e desenvolvimento tecnológico, por serem as relações jurídicas em projetos de inovação o foco específico desta análise, notadamente as que envolvem atores públicos e privados, como será abordado abaixo. O desenho adotado não significa afirmar que o ecossistema (ou sistema) de inovação não tenha outros elementos. Mazzucato e Penna (2016), por exemplo, adotam uma perspectiva ampla para caracterizar o ecossistema de inovação. Segundo eles, o ecossistema de inovação teria na base o contexto sócio-político, econômico, cultural e do meio ambiente do país, região ou localidade. Na camada seguinte estaria o governo e o aparato estatal, com a função de criar políticas públicas e financiamentos voltados à inovação. Em seguida, na descrição apresentada pelos autores, estaria a camada (ou subsistema) contendo empresas e seus laboratórios de pesquisa, responsáveis pela produção econômica e inovação, e também o subsistema de pesquisa e educação, formado por universidades, laboratórios públicos e instituições de pesquisa e tecnologia. Os autores terminam sua descrição do ecossistema de inovação acrescentando os mercados de bens e serviços, que fornecem insumos e recursos para as pesquisas e são os destinatários dos novos produtos, serviços e processos gerados com a inovação tecnológica, mercados esses que estão ao lado dos mercados financeiros, responsáveis também pelo financiamento a pesquisas e a empresas de inovação. Como se percebe, na descrição apresentada por Mazzucato e Penna (2016) são introduzidos elementos do ecossistema de inovação que não são apenas atores, empresas ou instituições, elementos como mercados e base sócio-político-econômico-cultural. Em nosso desenho, como já afirmado, pretendeu-se apresentar o ecossistema de inovação pelo ângulo dos atores e

\footnotetext{
${ }^{24}$ Em recente estudo (2016) realizado para o Centro de Gestão e Estudos Estratégicos (CGEE), organização social que atua junto ao Ministério da Ciência, Tecnologia, Inovações e Comunicações, Mariana Mazzucato e Caetano Penna mapearam o sistema de inovação brasileiro e procuraram seus problemas e virtudes visando fornecer orientações e recomendações par a a política de inovação nacional. Considerando os principais atores do sistema de inovação brasileiro apontados pelos autores e os colocando no nosso desenho de ecossistema de inovação, podemos reuni-los da seguinte forma, considerando a Administração Pública Federal: 1) Estado/Governo: Governo Federal e Ministérios, empresas (Petrobras, p. ex.) e bancos estatais (BNDES, p. ex.), agências reguladoras, instituições públicas de financiamento à pesquisa (FINEP, p. ex.); 2) Empresas: empresas privadas em geral que invistam em inovações; 3) Entidades da Sociedade civil: instituições privadas de pesquisa e/ou financiamento à pesquisa sem fins lucrativos, associações da indústria, organizações sociais (Embrapii, CGEE, p. ex.), universidades privadas que realizem pesquisas; 4) Universidades e instituições públicas de pesquisa: universidades federais, institutos federais de educação profissional, científica e tecnológica, entidades públicas de pesquisa (Embrapa, p. ex.).
} 
entidades que podem figurar como sujeitos (no sentido jurídico do termo) de negócios jurídicos para formação de parcerias em ciência, tecnologia e inovação.

Para a estruturação do ecossistema de inovação existe uma dimensão objetiva essencial sem a qual o ambiente de interação em prol de inovações não se desenvolve. A dimensão objetiva consiste na infraestrutura necessária para o surgimento de atores interessados em inovação e para que esse interesse se converta em pesquisa e desenvolvimento. Compõem essa infraestrutura as políticas públicas de fomento à inovação, mercados, pesquisadores, laboratórios e instrumentos de pesquisas, mercados para fornecimento de materiais, redes de conexão (Internet) para interligar pessoas e instituições, agentes financiadores, mercados de capitais, marco legal regulatório, recursos públicos, em suma, diversos elementos materiais e humanos sem os quais o ecossistema de inovação não surge. O ponto a ser aqui ressaltado é que o direito é um dos elementos que fazem parte dessa dimensão objetiva e importa para a formação do ecossistema de inovação.

O direito importa para o ecossistema de inovação porque as relações entre os seus diversos atores e instituições são relações jurídicas. Essas relações por meio das quais os diversos atores interagirão entre si serão formalizadas por contratos, convênios, ajustes, termos de cooperação, em outras palavras, por negócios jurídicos bilaterais ou plurilaterais. Os negócios jurídicos são vínculos jurídicos (obrigações) entre dois ou mais sujeitos em torno de um objeto, nos quais direitos e deveres são estabelecidos pelas vontades manifestadas das partes, ora com interesses recíprocos, ora opostos, aos quais o direito atribui força jurídica vinculante. A correspectividade de direitos e deveres é o meio pelo qual é formado o negócio jurídico para a consecução dos objetivos que movem cada um dos atores envolvidos. Através dessas relações jurídicas, formadas pela infinidade de negócios que as partes poderão gerar através da liberdade contratual, as múltiplas relações entre os agentes do ecossistema de inovação são formadas e surgem as parcerias em torno de pesquisas, bem como são definidas outras obrigações e direitos, tais como propriedade industrial, patentes, financiamentos e a colocação de inovações no mercado.

Sendo os negócios jurídicos os instrumentos por meio dos quais são constituídas as relações no ecossistema de inovação, é fundamental trazer ao debate a visão fornecida pela Análise Jurídica da Política Econômica - AJPE (CASTRO, 2014), segundo a qual, a economia de mercado é constituída por uma grande rede de agregados contratuais por meio dos quais os agentes buscam fruir seus direitos fundamentais. Na economia de mercado, segundo a AJPE, toda atividade econômica se realiza mediante contratos, por meio dos quais 
os indivíduos produzem, comercializam, distribuem e consomem bens e serviços. A rede de agregados contratuais é constituída por infinitas possibilidades de contratos (relações jurídicas) que são decisivos para dar acesso a direitos fundamentais ou congelar indivíduos em posições nas quais carecem desses direitos. Os direitos são identificados, segundo a AJPE, como "direitos de consumo ou de produção". No caso do ecossistema de inovação, parece claro que os direitos envolvidos são, imediatamente, de produção, dado que os diversos atores interagem entre si para produzirem novos bens, serviços e processos destinados ao mercado. Os contratos que formam a rede de agregados contratuais podem ter, na visão da AJPE, "conteúdos de interesse privado", estipulados livremente pelas partes, e "conteúdos de interesse público", impostos cogentemente pelo Estado. Essa combinação de conteúdos de interesse privado com conteúdos de interesse público é fundamental para o maior ou menor acesso a direitos fundamentais, sejam eles de produção ou de consumo, eis que poderão fazer com que os agregados contratuais, relativamente a determinado direito fundamental, facilitem ou criem obstáculos ao acesso a esse direito.

Se tomarmos para reflexão o ecossistema de inovação - que por ser uma parte da economia de mercado também tem seu funcionamento submetido à rede de agregados contratuais - veremos que determinados conteúdos de interesse público podem dificultar ou facilitar a fruição concreta do direito fundamental à liberdade de empreender, aqui caracterizada pela liberdade de realizar projetos de pesquisa para inovação de bens e serviços. Realmente, se considerarmos a atividade econômica de uma empresa que pretende inovar, a menor carga tributária (os tributos são um conteúdo de interesse público dos agregados contratuais) em atividades de inovação poderá fomentar pesquisas no ecossistema de inovação nacional.

Por outro lado, determinados conteúdos de interesse público dificultam o florescimento do ecossistema de inovação no país. Se considerarmos o Estado e as universidades públicas como agentes fundamentais do ecossistema de inovação brasileiro, observaremos que o regime jurídico das contratações da Administração Pública no Brasil contém diversas regras imperativas que dificultam e burocratizam a formação de parcerias público-privadas em inovação. A regra de realização de procedimento licitatório para todas as contratações públicas é um fator dificultante da formação de parcerias entre atores públicos e privados para desenvolvimento de pesquisas em inovação, em especial devido ao rito em regra lento de formação dessas parcerias que acaba tornando a relação desinteressante para o parceiro privado, que precisa da agilidade do mundo dos negócios privados. As regras rígidas 
de transferência ou cessão de recursos e bens públicos para instituições privadas também acabam por dificultar a realização de projetos de pesquisa com participação privada, nos quais a dificuldade de renovação para novos recursos atrasa empreendimentos e o melhor desenrolar das pesquisas. Prova desse fato é que as universidades públicas no Brasil, principalmente na esfera federal, recorrem em regra à formação de parcerias com fundações de apoio - entidades privadas sem fins lucrativos - para a realização de projetos de pesquisa, parcerias cuja principal função é jurídica, consistente em permitir uma fuga do regime jurídico administrativo por parte das universidades, dado que as contratações necessárias à realização das pesquisas ficam a cargo das fundações de apoio que, por serem entidades privadas, poderão contratar bens e serviços com maior flexibilidade e mediante procedimentos menos burocráticos.

O ponto que nos interessa destacar é o de como o direito das contratações públicas no Brasil poderá evoluir para facilitar a formação de parcerias público-privadas em inovação, com o fim de estimular o desenvolvimento do ecossistema de inovação nacional. A questão é a seguinte: qual a modelagem que o direito das contratações públicas deverá adotar para estimular a formação de parcerias público-privadas em inovação que ajudem a desenvolver o ecossistema de inovação brasileiro?

Para o enfrentamento dessa questão, adotamos como premissa o já demonstrado pressuposto de que o Estado Empreendedor é fundamental para o desenvolvimento nacional através das inovações e que um dos seus pressupostos conceituais é o da formação de parcerias público-privadas em inovação. Se o Estado e seus agentes (órgãos e instituições públicos) são atores fundamentais do ecossistema de inovação, e precisam interagir com atores privados para a realização de projetos de pesquisa e investimentos em inovações, logicamente as regras jurídicas que moldam essas relações (jurídicas) entre atores públicos e privados precisam ser as melhores possíveis na construção de um marco normativo que forneça segurança jurídica, flexibilidade, agilidade, transparência e controle (accountability). Esse inclusive é o papel que o direito deve exercer nas relações humanas em geral, fornecendo segurança e estabilidade para o desenrolar das diversas relações sociais, inclusive para abrir novos caminhos para o desenvolvimento econômico e social. Aqui é pertinente mencionar a observação de Georges Ripert (2002) que, ao analisar os aspectos jurídicos do capitalismo moderno, identificou que o direito, ao engendrar a figura das sociedades empresárias com personalidade jurídica própria, forneceu o combustível que alimentou o desenvolvimento do capitalismo moderno, ao conferir proteção, segurança, estabilidade e 
previsibilidade a diversos empreendimentos econômicos. O paralelo entre o direito das contratações/parcerias públicas e o das sociedades empresárias no início do desenvolvimento capitalista é pertinente porque ilumina a necessidade de o direito brasileiro superar gargalos burocráticos que dificultam a expansão do ecossistema de inovação nacional. Em outras palavras, o direito deve moldar-se às relações sociais para lhes conferir a regulação jurídica que estimule seu florescimento, ao invés de estabelecer regras que tolham as possibilidades de relacionamento entre os atores sociais. $\mathrm{O}$ direito como elemento apenas proscritivo não se encaixa no mundo contemporâneo de alta mutabilidade e agilidade das relações humanas.

Adotamos ainda como premissa a hipótese de que se deve conferir uma regulação específica para os negócios jurídicos da Administração Pública em matéria de inovação, que não podem ser tratados na regra geral das contratações públicas porque possuem elementos específicos que os singularizam, a exigirem tratamento diferenciado para o fomento do ecossistema de inovação nacional. Buscaremos, portanto, esses elementos específicos que marcam as relações jurídicas em ciência, tecnologia e inovação, e quais as características mínimas que o direito das contratações públicas deve ter quando envolver pesquisa científica para produção de novos conhecimentos e tecnologias.

\section{1 - Aspectos gerais do regime jurídico das contratações públicas}

Conforme colocado acima, as relações entre os diversos atores pertencentes ao ecossistema de inovação serão necessariamente relações jurídicas, porque será preciso uma formalidade jurídica por meio da qual sejam estabelecidos direitos e deveres recíprocos entre as partes para conferir segurança aos empreendimentos conjuntos que resolvam realizar.

Interessam-nos os negócios jurídicos que envolvam os atores públicos, porque consideramos que são as relações que os envolvem que necessitam de estruturação específica e diversa daquela que em regra molda os negócios jurídicos da Administração Pública. Interessa-nos, portanto, o regime jurídico dos negócios da Administração Pública, em outras palavras, quais as características específicas que esses negócios devem ter quando envolvam parcerias sobre ciência, tecnologia e inovação para que a relação dos atores públicos, em especial com atores privados, tenha a dinâmica exigida pelas pesquisas. Por regime jurídicoadministrativo dos negócios da Administração Pública em ciência, tecnologia e inovação entendemos as características específicas e os fatores que os distinguem dos demais negócios 
jurídicos celebrados pela Administração em suas múltiplas funções. São as regras e os princípios que formam uma instituição jurídica específica em relação às demais, as diferenças que singularizam esses negócios no universo dos contratos e parcerias do Poder Público.

Para identificarmos os elementos que particularizam o regime administrativo dos negócios jurídicos da Administração Pública em ciência, tecnologia e inovação, partiremos da observação das características de formação e execução dos negócios jurídicos da Administração Pública em geral, a fim de fazer o contraponto e ressaltar as especificidades que marcam as parcerias em CT\&I. As regras gerais para as contratações públicas estão definidas na atual lei de licitações e contratos (Lei no 8.666, de 21 de junho de 1993), que possui fundamento no art. 37, XXI da Constituição Federal ${ }^{25}$.

Nessa esteira, o regime jurídico-administrativo geral dos negócios da Administração Pública tem como regra fundamental a realização de procedimento seletivo para a escolha de com quem o Poder Público contratará, as licitações públicas. A licitação é o procedimento administrativo por meio do qual a Administração Pública define com quem celebrará um contrato administrativo para alienação, aluguel ou aquisição de bens e/ou prestação de serviços ${ }^{2627}$. Por meio das licitações públicas, busca-se conferir tratamento isonômico a todos os que tenham condições de contratar com a Administração. Ou seja, a Administração tem o dever de oferecer condições objetivas equânimes para todos os potenciais contratantes, sendo-lhe vedada, em regra, a contratação direta de determinadas pessoas em detrimento dos demais sem uma justificativa admitida em lei (inexigibilidade ou dispensa de licitação, por exemplo). Por meio da licitação, pretende-se também alcançar a proposta mais vantajosa para a Administração, mediante estabelecimento de disputa entre os participantes do certame licitatório com vistas à obtenção do melhor preço e/ou dos melhores bens e serviços.

\footnotetext{
25 Além das contratações públicas, a Administração poderá formalizar outras espécies de negócios jurídicos, como, por exemplo, os convênios com organizações da sociedade civil, regidos pela Lei no 13.019 , de 31 de julho de 2014, ou contratos de gestão com organizações sociais, nos termos da Lei n- 9.637, de 15 de maio de 1998. Contudo, por ser a lei de licitações e contratos o principal estatuto relacionado aos negócios jurídicos da Administração Pública, bem como por uma questão de delimitação de objeto de estudo, abordaremos apenas as questões envolvendo a mencionada Lei no 8.666 , de 21 de junho de 1993.

${ }^{26}$ Por meio dos procedimentos licitatórios a Administração também seleciona pessoas para a celebração de contratos com objetivos mais específicos, a exemplo das concessões e permissões de serviços públicos. Contudo, pretendemos ressaltar neste trabalho as contratações mais ordinárias e presentes no dia a dia do funcionamento da Administração Pública, abrangidas pela Lei no -8.666 , de 1993 .

${ }^{27}$ Celso Antônio Bandeira de Mello (2006) define licitação como "um certame que as entidades governamentais devem promover e no qual abrem disputa entre os interessados em com elas travar determinadas relações de conteúdo patrimonial, para escolher a proposta mais vantajosa às conveniências públicas".
} 
É importante ressaltar que através do procedimento licitatório é imposta clara limitação à autonomia da Administração em escolher com quem pretende celebrar contrato. Limitação que, embora justificável em razão da isonomia de tratamento a ser concedida a todos os potenciais contratantes, resulta num cerceamento da liberdade contratual da Administração, que não poderá contratar senão mediante o rito do procedimento licitatório. Esse rito, por sua vez, consome tempo e impõe à Administração uma diminuição da celeridade de formação dos seus negócios jurídicos. Por outro lado, a disputa gerada entre os participantes do processo licitatório busca a aquisição dos melhores bens e serviços ao menor preço possível para a Administração, do que sobressai a preocupação patrimonial e material do processo licitatório.

Da necessidade de atender ao primado da isonomia nas contratações públicas, os procedimentos licitatórios devem ser abertos à ampla concorrência, ou seja, devem ser abertos à participação ampla de todos os que desejem postular a posição de contratados pelo Poder Público, do que resulta a impossibilidade de erigir critérios que bloqueiem arbitraria e injustificadamente a participação ampla das pessoas que queiram ingressar nos certames.

Simultaneamente, as licitações públicas e os contratos administrativos delas gerados são marcados pela regra da vinculação ao instrumento convocatório do certame (edital), no que resulta a impossibilidade de alteração do objeto contratual, seja durante a realização do procedimento licitatório, seja na execução do contrato. Isto implica que as partes contratantes não poderão alterar o objeto contratual (imutabilidade do objeto contratual), dado que tal alteração seria considerada uma burla ao processo de seleção e uma violação ao direito dos demais licitantes vencidos no certame que concorrem para objeto definido.

Outra característica marcante do processo licitatório e dos contratos administrativos submetidos ao regime jurídico geral das contratações públicas é a forte centralização na lei para a definição dos direitos e deveres no negócio jurídico. Há pouca margem para que as partes, no exercício da liberdade contratual, possam estipular direitos e deveres no negócio jurídico. Pelo contrário, a Lei no 8.666, de 1993, é bastante densa na estipulação de regras cogentes (conteúdos de direito público, para utilizar a expressão da Análise Jurídica da Política Econômica) a serem cumpridas pelas partes. Pouco espaço resta para a definiçãa de conteúdos jurídicos contratuais pelas partes, em geral restrita à definição do objeto e a questões expressamente deixadas em aberto para definição dos contratantes. Segundo Marçal Justen Filho (2012), nos processos licitatórios, o princípio da legalidade 
vincula o administrador ao ponto de ele não poder adotar providência ou estabelecer restrição sem prévia autorização legislativa. Além disso, há densa regulamentação da lei geral de licitações, em especial no âmbito da Administração Pública Federal, com decretos, portarias e instruções normativas ${ }^{28}$ que aprofundam regras a serem seguidas pelas partes nas contratações públicas. Essa abundância de normas legais e infralegais que regem os procedimentos licitatórios e os contratos administrativos é causa de intensa burocratização na celebração e execução dos negócios jurídicos do Poder Público. Na metalinguagem dessas normas está a preocupação em cercar os procedimentos administrativos de todas as cautelas para evitar malversação e desvio do dinheiro público, o que resulta numa formalização intensa dos procedimentos de contratação pública.

Daí decorre outra característica peculiar aos processos licitatórios e aos contratos administrativos: o controle e a fiscalização focados na questão patrimonial, na prestação de contas e no cumprimento do objeto contratual. Deve-se comprovar, durante a execução contratual e ao seu término, que os recursos públicos foram devidamente empregados e o objeto contratual plena e adequadamente cumprido. Trata-se, em outras palavras, da avaliação por prestação de contas e pelo cumprimento contratual, a adoção do controle por procedimentos.

É de ser apontado também, por importante, que o regime das contratações públicas definido na lei geral de licitações tem por escopo principal a contratação de bens $e$ serviços como elementos-meio para a Administração Pública realizar suas funções institucionais. O Poder Público, para prestar os serviços e realizar atividades essenciais à comunidade - segurança, saúde, educação, funcionamento do Judiciário, atividade legislativa etc.-, necessita de uma infinidade de bens e serviços sem os quais não terá estrutura material para executar suas funções institucionais. Ou seja, bens e serviços contratados mediante licitações públicas são ferramentas para a prestação dos serviços públicos ${ }^{29}$. São, por exemplo, os materiais e serviços que um órgão público necessita para manter seu funcionamento. Por conseguinte, o regime jurídico-administrativo das contratações públicas volta-se, em regra, para suprir a Administração de bens e serviços, fornecidos por terceiros, necessários à realização do seu mister institucional.

\footnotetext{
${ }^{28}$ A Instrução Normativa no 2, de 30 de abril de 2008, e posteriores alterações, do Ministério do Planejamento, é um exemplo significativo da densidade normativa cogente nas contratações públicas em nível federal.

${ }^{29}$ Nas licitações para a concessão e permissão de serviços públicos, por outro lado, a Administração seleciona pessoas para prestação de serviços que são atividades-fim do Poder Público. Contudo, a sistemática de contratação é peculiar e foge da regra geral porque há com a contratação uma delegação de serviços públicos, e o contrato administrativo, por consequência, tem uma série de regras específicas em razão da delegação, inclusive como a possibilidade de encampação dos serviços pelo Poder Público.
} 
Em suma, na tentativa de sintetizar as características mais marcantes do regime geral de contratações públicas definido no direito brasileiro, pode-se afirmar ele que tem na licitação pública sua regra fundamental, realizada mediante procedimento densamente definido em lei e normas infralegais, que gera uma limitação da autonomia administrativa na medida em que fecha as possibilidades de criação de direitos e deveres pelas partes, obriga o Poder Público a conceder ampla possibilidade de concorrência aos interessados em com ele contratar e a ficar vinculado ao objeto contratual definido no instrumento convocatório, sobressaindo clara preocupação patrimonial, inclusive no controle de procedimentos e por prestação de contas, com a finalidade de adquirir, em regra, bens e serviços como meios de realização de suas funções institucionais.

Posto isso, para que o direito contribua na formação de um ecossistema de inovação robusto no Brasil, o regime administrativo dos negócios jurídicos que envolvam ciência, tecnologia e inovação deverá apresentar uma série de características específicas moldadas para este objeto, a fim de conjugar celeridade na formação de parcerias públicoprivadas, flexibilidade para adaptação dos negócios aos rumos das pesquisas, segurança jurídica na definição e cumprimento dos direitos e deveres estabelecidos, transparência na prestação de contas e controle de resultados. Certamente, esses objetivos somente poderão ser alcançados com elementos específicos que diferenciem os negócios jurídicos em CT\&I dos contratos em geral celebrados pela Administração Pública. Isso se faz com o reconhecimento de que se está a tratar com objetos distintos que, logicamente, exigem regulações jurídicas diversas. O direito deve moldar-se ao fato regulado, não o oposto. Nesse sentido, o regime geral das contratações públicas, marcado pelo excesso de formalismo, deverá apresentar configuração nova para viabilizar os negócios jurídicos em inovação tecnológica.

Aqui é pertinente ressaltar a função promocional do direito apontada por Norberto Bobbio (1977) como provocadora de mudança no status quo. Segundo autor, para além das regras proibitivas típicas do direito liberal, de função conservadora, o direito surgido com o Estado Social assume também a função promocional, resultante da acolhida de novos deveres pelo Estado, a exigirem modificações e inovações inclusive no próprio direito. A função promocional resulta no incentivo a comportamentos desejados pelo Estado e compatíveis com objetivos de interesse público, para cuja finalidade o direito estabelece normas (promocionais) que contribuem para a mudança social. Na linha desse argumento, o próprio direito deve mudar, inovar-se, para fazer frente às suas novas funções. Esse é o ponto a destacar acerca do regime jurídico das contratações públicas, que deverá apresentar elementos novos para melhor 
regular as parcerias público-privadas em CT\&I, qualquer que seja a modalidade de negócio jurídico por meio do qual projetos de pesquisa sejam formalizados.

\section{2 - O regime jurídico-administrativo dos negócios da Administração Pública em ciência, tecnologia e inovação}

Cumpre, a partir de agora, tentar sistematizar os aspectos gerais de um regime jurídico-administrativo próprio para as contratações e demais formas de parcerias entre atores públicos e privados em ciência, tecnologia e inovação. Essas características servirão de marco para delimitar uma área específica de funcionamento administrativo na qual as instituições jurídicas sejam interpretadas e aplicadas conforme as necessidades das pesquisas e da produção de inovações tecnológicas.

O primeiro passo nesse sentido é a definição do que se entende por contratações $e$ parcerias público-privadas em ciência, tecnologia e inovação. Esses negócios jurídicos são aqueles cujo objeto envolva, direta ou indiretamente, pesquisas que tenham por objetivo a inovação tecnológica de produtos, processos e serviços, conforme definidos na introdução deste trabalho, de acordo com o Manual de Oslo. A Lei de Inovação é clara quando considera inovação ${ }^{30}$ aquela que resulta em processos, produtos e serviços novos ou aperfeiçoados, no ambiente social ou produtivo. É a inovação voltada, como prescrito no art. $1^{\text {o3}}{ }^{1}$ da mesma lei, para o desenvolvimento do ambiente produtivo nacional e regional do país, visando à capacitação tecnológica e ao alcance da autonomia tecnológica nacional. Em outras palavras, não é qualquer pesquisa que pode ser classificada como de ciência, tecnologia e inovação, mas tão somente aquelas que visem gerar novos produtos, serviços e processos, ou aperfeiçoar os já existentes para lhes conferir ganho de qualidade ou desempenho, com vistas ao desenvolvimento da indústria e do mercado interno nacional. Dessa forma, ficam fora do conceito de negócio jurídico em CT\&I as pesquisas, projetos ou parcerias que visem a inovação de ensino, extensão, desenvolvimento institucional, práticas de gestão e

\footnotetext{
${ }^{30}$ Lei no 10.973 , de 2004, art. $2^{\circ}$, IV - inovação: “introdução de novidade ou aperfeiçoamento no ambiente produtivo e social que resulte em novos produtos, serviços ou processos ou que compreenda a agregação de novas funcionalidades ou características a produto, serviço ou processo já existente que possa resultar em melhorias e em efetivo ganho de qualidade ou desempenho".

${ }^{31}$ Art. $1^{\circ}$ - Esta Lei estabelece medidas de incentivo à inovação e à pesquisa científica e tecnológica no ambiente produtivo, com vistas à capacitação tecnológica, ao alcance da autonomia tecnológica e ao desenvolvimento do sistema produtivo nacional e regional do País, nos termos dos arts. 23, 24, 167, 200, 213, 218, 219 e 219-A da Constituição Federal.
} 
administração, enfim, qualquer atividade que não caracterize pesquisa e inovação com o escopo de inserir novos produtos, processos e serviços no mercado para o desenvolvimento da indústria nacional.

Esses negócios jurídicos em CT\&I abrangem uma série de arranjos e formas que podem ser contratos de financiamento, de cessão de bens, aquisição de máquinas e instrumentos, utilização de laboratórios e demais imóveis, tudo o que direta ou indiretamente tenha por escopo pesquisa para o desenvolvimento de inovação de produtos, processos e serviços. O ponto de identificação reside no objetivo final do contrato, se este visa ou não à realização ou ao suprimento de recursos para a pesquisa de inovações tecnológicas de produtos, processos e serviços. Com efeito, para a realização de pesquisas, uma enorme quantidade de elementos deve se fazer presente: recursos humanos e materiais, laboratórios, recursos financeiros, máquinas e instrumentos, dentre outros. Os contratos que envolvam a pesquisa propriamente dita e os que abranjam os demais elementos necessários deverão ser considerados de (os primeiros), ou vinculados à (os segundos), ciência, tecnologia e inovação, a merecerem um tratamento jurídico diferenciado.

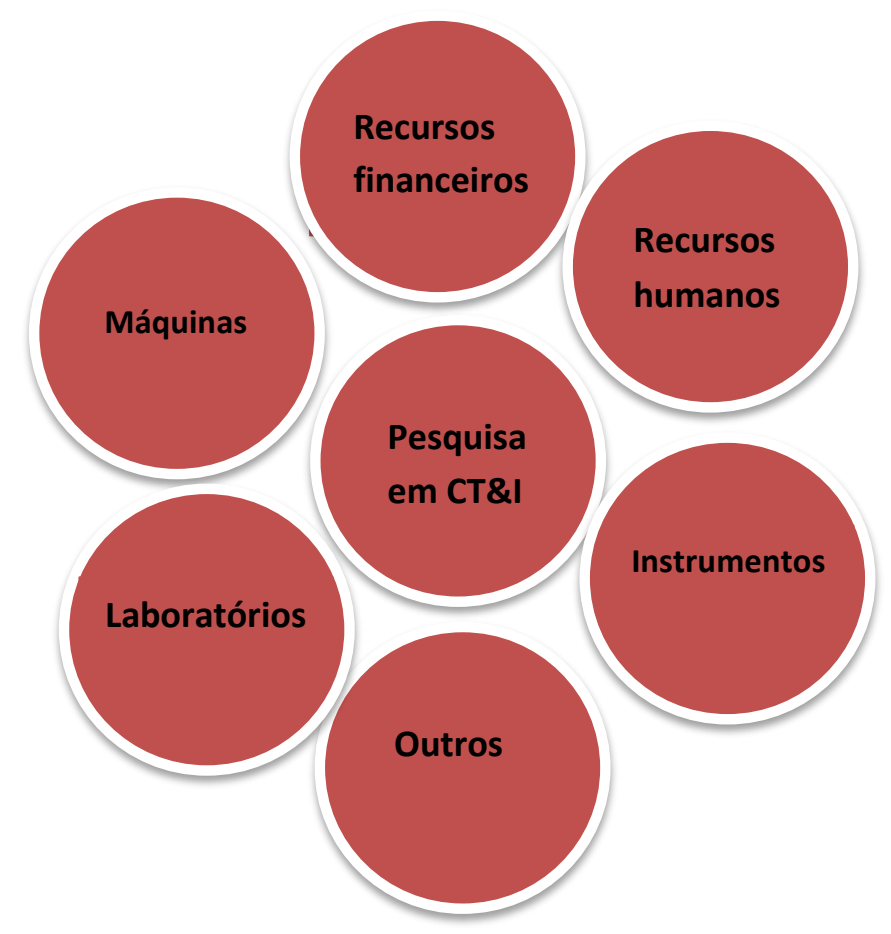

Além do negócio jurídico principal, que diz respeito às pesquisas (básicas ou aplicadas $^{32}$ ) propriamente ditas, outros negócios serão realizados para aquisição e

32 Pesquisa básica é aquela que busca a formação do conhecimento científico novo. A pesquisa aplicada tem por objetivo empregar o conhecimento científico básico na solução de problemas concretos, mediante o desenvolvimento de tecnologias 
fornecimento de bens e serviços, material humano, financiamentos, para suprir as pesquisas de infraestrutura e recursos necessários. Há, portanto, um contrato (ou mais) principal, cujo objeto são as pesquisas, e também contratos acessórios, vinculados finalisticamente aos primeiros porque os tem como objetivo direto, por meio dos quais os atores envolvidos nas pesquisas obterão os elementos necessários para a realização do contrato principal. Em termos práticos, pode-se imaginar um contrato (principal) para a realização de pesquisa básica entre universidade pública e empresa, e contratos acessórios por meio dos quais a universidade comprará máquina e instrumentos para a realização da pesquisa. Todos esses contratos, é importante dizer, são relevantes para a atividade de CT\&I, porque sem a máquina e demais insumos as pesquisas não acontecem. O ponto a ressaltar é que também os contratos acessórios aos das pesquisas devem estar submetidos ao mesmo regime jurídico do contrato principal. Seria incoerente apresentar um regime célere de formação de parcerias públicoprivadas em inovação e manter o regime geral de contratações para os contratos que visam fornecer bens e serviços para o primeiro, engessando a pesquisa em razão da burocracia na aquisição de insumos.

Portanto, deve-se entender como contratos e demais negócios jurídicos em ciência, tecnologia e inovação não só os que tenham como objeto pesquisa básica e aplicada para inovação de produtos, processos e serviços, mas também os demais, vinculados ao primeiro, que tenham por objetivo fornecer insumos e a infraestrutura material e humana para a realização das pesquisas.

Estabelecido esse conceito, o primeiro cânone de um regime jurídicoadministrativo próprio das contratações e parcerias em CT\&I é a não obrigatoriedade de procedimento seletivo para a definição dos parceiros privados, em outras palavras, o afastamento da compulsoriedade de licitação.

É preciso ter em mente, para chegar ao primeiro postulado, que o desenvolvimento nacional sustentável através de inovações é uma das funções institucionais do Estado, que “(...) promoverá e incentivará o desenvolvimento científico, a pesquisa, a capacitação científica e tecnológica e a inovação", segundo o prescrito no art. 218 da Constituição Federal. Isto significa que, ao contrário das demais contratações públicas, que visam à obtenção de bens e serviços como meios para as atividades do Estado, a produção de inovações tecnológicas e/ou sua promoção é dever institucional do Estado brasileiro.

que ofereçam estas soluções. Daí se percebe ser mais difícil a realização da pesquisa básica, pois se parte do zero e o grau de incerteza (no sentido expresso no capítulo primeiro) é maior. 
Inovação tecnológica de produtos, processos e serviços para o desenvolvimento sustentável e do mercado nacional é atividade-fim do Poder Público. Aqui reside o elemento principal distintivo dessas contratações e parcerias em relações às demais regidas pelo regime administrativo geral dos negócios jurídicos do Poder Público. Enquanto nas contratações de bens e serviços para suprir o funcionamento diário da máquina estatal as contratações visam equipar a Administração para suas funções institucionais, em CT\&I essas contratações estão no rol das atividades-fim do Estado. Nas contratações públicas em geral, existem interesses contrapostos entre a Administração, que pretende bens ou serviços, e as empresas contratadas, que buscam auferir lucro. Nas parcerias entre atores públicos e privados em CT\&I, há bem mais clara a presença de interesses convergentes, na conjunção de esforços para a realização de pesquisas.

Em razão de as pesquisas em CT\&I estarem inseridas nas suas atividades institucionais, é que o Estado deverá ter ampla liberdade para formar parcerias diretamente com as entidades privadas, com ou sem fins lucrativos, que reúnam as condições necessárias para a realização de pesquisas. Enquanto nas licitações públicas em geral o objetivo é assegurar a isonomia de tratamento entre os potenciais contratantes com o Poder Público, selecionar a proposta mais vantajosa para a Administração e promover o desenvolvimento nacional sustentável através das contratações públicas (art. 3ำ da Lei $n^{\circ}$ 8.666/93), na formação de parcerias em CT\&I o objetivo é dotar o Poder Público da liberdade de escolha do melhor parceiro privado para a realização de empreendimentos em inovação tecnológica. $\mathrm{O}$ Estado, ou suas entidades vinculadas, estará exercendo sua função institucional de eleger o melhor caminho para promover, realizar e incentivar o desenvolvimento científico e tecnológico. Essa liberdade de contratação abrange tanto os contratos principais quanto os dele derivados, ligados direta ou indiretamente à produção de CT\&I.

A liberdade de formação de parcerias, por outro lado, não se confunde com arbitrariedade, porque o meio legítimo de sua realização deverá ser através da motivação administrativa adequada e suficiente. Em outros termos, o Poder Público poderá formar parceria diretamente com entidade pública ou privada, com ou sem fins lucrativos, contudo deverá apresentar justificativa adequada para tanto, indicando com clareza por quais fundamentos técnicos determinado parceiro foi escolhido. A motivação administrativa é um dos princípios cardeais da Administração Pública, através dela é feita a exteriorização das razões de fato (técnicas, econômicas, políticas etc.) e de direito pelas quais determinado ato 
foi ou será praticado. Como afirma Juarez Freitas (2013), o dever de motivar é essencial para a realização do direito fundamental à boa administração pública.

Há uma série de elementos objetivos por meio dos quais a Administração poderá justificar a escolha de determinado parceiro privado: expertise técnica, capacidade financeira, corpo de pesquisadores reconhecidos, adequação da política de inovação da entidade/empresa aos objetivos da política nacional de ciência, tecnologia e inovação e às demandas do mercado e indústria nacionais, estrutura física de reconhecida qualidade, dentre outros. O planejamento da pesquisa, com demonstração técnica suficiente e adequada, aliado à justificativa (motivação administrativa) plena da opção da Administração, serve de critério balizador e de escrutínio das decisões de formação de parceria, mesmo sem realização de processo seletivo, a permitir a preservação do interesse público, da moralidade e probidade administrativas, atendendo às finalidades institucionais da Administração em ciência, tecnologia e inovação. Mediante a exteriorização, por parte da Administração, dos elementos objetivamente aferíveis que levaram à formação da parceria com determinada empresa ou entidade privada e não outra, condizente com a política pública de inovação, será possível aferir a legitimidade da escolha do Poder Público dentro de sua margem de discricionariedade para decidir o que contratar, com quem, quando e em que termos. Essa discricionariedade, embora confira à Administração Pública a liberdade e agilidade de formar parcerias, por outro lado lhe impõe, através da obrigação de motivação das decisões, os limites que bloqueiam o arbítrio, evitam os privilégios a quem não tem aptidão e permite a sindicância das parceiras pela sociedade e órgãos de controle. Ademais, a formação de parcerias sem a adequada, suficiente, prévia (indicativa de planejamento) e congruente motivação administrativa macula de ilicitude a celebração do negócio jurídico, sendo, portanto, condição de validade do empreendimento.

A não realização de procedimento seletivo para a formação de parceria não impede, obviamente, que a Administração lance mão de seleção de projetos de pesquisa e parceiros para o desenvolvimento de novos produtos, processos e serviços. O chamamento público continua sendo um procedimento importante por meio do qual a Administração procurará bons parceiros privados para a realização de pesquisas. Por outro lado, a não obrigatoriedade de licitação cria a possibilidade de empresas com bons projetos procurarem o Poder Público (universidades públicas em especial) para formarem parcerias, e também de o Poder Público e as universidades procurarem empresas para a constituição de parcerias, evitando que se percam boas oportunidades de empreendimentos conjuntos em razão da vinculação à regra que determina a realização de um procedimento prévio, que consome 
tempo e burocratiza a formação dos negócios. A consequência desse postulado é que o Poder Público, e em especial as instituições públicas voltadas para pesquisa científica, como as universidades, terão mais autonomia para a realização de suas funções.

A segunda característica que marca o regime jurídico das contratações públicas em ciência, tecnologia e inovação é a possibilidade de alteração do objeto contratual, em oposição à regra da vinculação ao instrumento convocatório que impõe a vinculação estrita ao objeto inicial do negócio celebrado.

A possibilidade de alteração do objeto contratual decorre fundamentalmente da incerteza que marca as pesquisas científicas. Como vimos no capítulo primeiro, as pesquisas para a criação de novos produtos, processos e serviços são imprevisíveis em seus resultados. Não há como prever o resultado positivo dos empreendimentos, nem o tempo e os recursos a serem gastos. O sucesso das pesquisas é absolutamente uma incógnita. Nesse cenário, diversas situações podem ocorrer, inclusive a possibilidade concreta de desenvolver produto, processo ou serviço que inicialmente não era o alvo das pesquisas, mas que se apresentou viável em razão das diversas hipóteses, testes e materiais empregados. Faz parte do processo de produção de novos conhecimentos a possibilidade de experiências que buscam confirmar determinadas hipóteses científicas acabarem por revelar outros conhecimentos imprevistos. É conhecida a criação do forno micro-ondas por Percy Spencer quando trabalhava na fabricação de magnetrons para radares, quando percebeu que emitiam ondas. Aplicando-as em alimentos, constatou que o instrumento poderia aquecer vários tipos de comida, o que resultou na invenção do forno micro-ondas. Isso ocorre porque as diversas experiências realizadas podem refutar hipóteses, mas também revelar outras, abrindo caminhos para novas descobertas. Assim, uma pesquisa que inicialmente tinha determinado produto como alvo e que se mostrou inviável, pode dar lugar a outra inovação. Juridicamente, o contrato formado entre o ente público e a empresa/entidade privada deve poder ser ajustável ao novo objetivo, redirecionamento as pesquisas, recursos, pessoal e investimentos ao novo empreendimento. $\mathrm{O}$ direito deve oferecer essa flexibilidade jurídica aos parceiros do empreendimento para adaptar-se à natureza imprevisível das pesquisas científicas. Não teria sentido que um objeto não mais desejado pelas partes em razão de sua inviabilidade constatada não pudesse ser redirecionado para novos objetivos definidos. Seria o direito se negando à possibilidade de se moldar ao fato regulado e impedindo a realização dos empreendimentos humanos. Em razão disso, fato imprevisível consequência de incerteza tecnológica que mude os rumos das pesquisas deve poder dar ensejo à alteração do objeto do contrato/parceria, com o rearranjo 
dos demais elementos e obrigações contratuais decorrentes. Essa alteração pode significar, também, acréscimo no objeto, não apenas mudança para outro alvo. Em outras palavras, pode acontecer que novas possibilidades de pesquisas surjam sem o abandono das pesquisas iniciais, resultando na adição ao objetivo inicial, ou ainda na formação de novas parcerias.

Aqui, mais uma vez, seja na mudança de objeto, ou em seu acréscimo, a motivação administrativa deverá se fazer presente para a demonstração dos elementos técnicos que justifiquem os novos rumos da pesquisa, como condição de validade da alteração contratual, exibindo porque novos alvos são viáveis, e, em sendo o caso, porque a pesquisa inicial não foi bem-sucedida. A motivação administrativa, tal qual na formação do contrato e definição do parceiro privado, servirá de baliza para evitar que a mudança de objeto sem o devido planejamento e fundamento técnico sirva de pretexto para cometimento de arbitrariedades e concessão de privilégios.

As contratações e parcerias em CT\&I precisam apresentar regras desburocratizadas para uso, cessão e compartilhamento de bens públicos móveis e imóveis. $\mathrm{O}$ regime de gestão dos bens públicos, quando direcionados aos contratos de pesquisa e inovação tecnológica, deverá ser o mais flexível e desburocratizado possível, a permitir o emprego do patrimônio público com a celeridade e facilidade que o ecossistema de inovação exige. As pesquisas científicas necessitam de ambientes especializados para sua realização (laboratórios) e de instrumentos, máquinas e insumos sem os quais não é possível a criação do conhecimento básico ou aplicado. Esses recursos são objeto das negociações acessórias aos contratos principais (ou também tratados no próprio contrato principal), devendo estar, portanto, submetidos ao mesmo regime jurídico facilitador das parcerias público-privadas em inovação.

O regime jurídico dos bens públicos aplicados em pesquisa e inovação tecnológica é uma questão essencial porque em muitas parcerias a contrapartida das partes poderá ser definida através da disponibilização de seus bens. No caso, podemos citar o exemplo de uma parceria entre universidade pública e empresa, no qual a contrapartida do ente público seja a disponibilização de seus laboratórios, instrumentos, máquinas e insumos para que os pesquisadores da empresa realizem as pesquisas. $\mathrm{O}$ auxílio material para as pesquisas, nesse caso, não se dá apenas com financiamentos, mas também através do patrimônio público especificamente aplicado em CT\&I.

Esses bens, consequentemente, deverão estar previamente afetados ao emprego em contratos e parcerias de pesquisa e inovação tecnológica para que possam, após a 
celebração de um negócio jurídico principal por uma entidade ou órgão públicos, serem disponibilizados para sua aplicação nas pesquisas, num procedimento simples e rápido. Uma alternativa possível nesse sentido seria conferir força jurídica aos negócios em CT\&I para que, por si sós, já tenham o condão de produzir efeitos sobre o patrimônio público (bens móveis e imóveis) afetado às pesquisas e utilizado, cedido e compartilhado com agentes privados do ecossistema de inovação que firmem parcerias com atores públicos. O regime dos bens públicos destinados à CT\&I seria mais flexível e definido através dos contratos e instrumentos congêneres, em contraposição ao regime geral, marcado pela rigidez e procedimentos previstos em lei. Tal medida permite, inclusive, a utilização do mesmo bem móvel ou imóvel em mais de uma parceria, desde que esses bens comportem mais de um ou vários usuários. De uma forma ou de outra, o importante é salientar a necessidade de que o patrimônio público destinado às pesquisas científicas possa estar disponível sem burocracia para servir às parcerias, sem descurar, por outro lado, do controle e fiscalização adequados.

Outra característica do regime de contratações e negócios jurídicos em CT\&I é a simplificação e desburocratização das formas e mecanismos de controle, inclusive com a adoção do controle por resultados. Sem descuidar da transparência, especialmente no gasto do dinheiro público, as parcerias público-privadas em inovação poderão estabelecer nos negócios jurídicos celebrados regras mais práticas de prestação de contas, formas mais céleres de demonstrar como e porque foi gasto o dinheiro público. Em contraposição ao controle de procedimentos rígidos definidos em lei e normas infralegais característico da execução contratual da Administração Pública, as parcerias em CT\&I poderão lançar mão de procedimentos de controle adotados na esfera privada, com regulamentos desburocratizados, com vistas inclusive a facilitar a aquisição mais rápida de máquinas, instrumentos e insumos para as pesquisas, com possibilidade de comprovação após a aquisição, por exemplo, ou ainda a adoção de recursos da tecnologia da informação para documentar a prestação de contas. Como exercício da liberdade contratual, as partes poderão estabelecer nos documentos de parceria as regras de transparência e prestação de contas. As entidades públicas de pesquisa, a exemplo das universidades, poderão estabelecer regulamentos próprios em que adotem padrão de accountability para suas parcerias com o setor privado. De uma forma ou de outra, embora visando à desburocratização e à celeridade na realização das pesquisas, as parcerias não poderão abrir mão da transparência, da prestação de contas na aplicação dos recursos públicos e da fiscalização pelos diversos órgãos de controle externo, interno e social. 
A adoção de mecanismos de controle por resultados também é adequada às parcerias em CT\&I, tendo em vista a busca de objetivos específicos, no caso a produção de conhecimentos que resultem em bens, serviços e processos inovadores. Nesse processo de pesquisa e criação, é possível pensar em estabelecer critérios objetivamente aferíveis e próprios ao universo das pesquisas que possam indicar seu avanço ou estagnação, com base nos quais se possa avaliar a utilidade em manter ou não a parceria. A eleição de indicadores e metas objetivas permite avaliar os resultados alcançados dentro do processo de evolução da produção científica. É preciso considerar que o ambiente de incerteza que marca a pesquisa tecnológica pode resultar no insucesso da produção de novos bens, serviços ou processos no tempo inicialmente previsto na parceria, mas, contudo, resultar na produção de conhecimentos parciais indicativos de que o objetivo principal, mais cedo ou mais tarde, será alcançado. Nesse contexto, o estabelecimento de metas e indicadores pertinentes poderá fornecer elementos concretos que demonstrem a necessidade de manter a parceria e as pesquisas, mesmo com o insucesso em obter a inovação tecnológica alvo no tempo inicialmente estabelecido. Por essa razão, o controle por resultados, paralelo ao controle do gasto público de forma desburocratizada, é importante para as parcerias em ciência, tecnologia e inovação.

Todas essas características revelam que no regime jurídico das contratações e negócios públicos em ciência, tecnologia e inovação, no qual se busca flexibilidade normativa para atingir maior adaptabilidade às várias possibilidades de pesquisas e parcerias, serão $o s$ contratos e instrumentos congêneres (convênios, acordos, termos de cooperação, dentre outros) a principal fonte normativa das regras que regularão essas relações, ao contrário do regime geral de contratações públicas que tem na lei sua principal fonte de direitos e obrigações.

Com efeito, as partes que firmarão as parcerias público-privadas em CT\&I poderão exercer em maior amplitude a liberdade contratual para criar direitos e deveres que se adaptem às múltiplas possibilidades e peculiaridades das pesquisas, e aos diversos interesses, econômicos em especial, envolvidos nessas relações. Paulo Todescan Lessa Mattos (2009) denomina de "regulação por contrato os instrumentos e arranjos jurídicos-institucionais que dão suporte à atuação do Estado como tomador de risco", caracterizada pela utilização de instituições do direto privado para moldar parcerias, aplicação de recursos e fomento a empreendimentos sem recorrer às formas tradicionais de intervenção do Estado na ordem econômica. A adoção de contratos e demais instrumentos constituídos pela vontade das partes passa a ser o principal mecanismo para induzir a formação de parcerias público-privadas em 
pesquisa e desenvolvimento científico e tecnológico. Esses instrumentos conferem maior maleabilidade às partes na composição de direitos e deveres recíprocos, na construção de empreendimentos conjuntos em inovação, o que pode e deve abranger vários aspectos envolvidos nesses negócios, como alocação dos recursos (financiamentos), contrapartidas materiais, definição dos direitos de propriedade industrial, fiscalização e prestação de contas, gestão de recursos físicos e humanos aplicados às parcerias.

O deslocamento da principal fonte normativa da lei para os contratos e demais negócios jurídicos estabelecidos pelas partes permite a mudança rápida dos regramentos que incidem nas parcerias para abranger novas situações e demandas dos diversos atores do ecossistema de inovação. Como órgãos e instituições públicas serão atores fundamentais nesse processo, eles passam a ser também elementos utilizados pelo Estado para formar parcerias com determinadas regras e objetos que atendam aos objetivos da política nacional de inovação, passando a ser instrumentos regulatórios aos quais o Estado poderá lançar mão para induzir o mercado através de formação de parcerias em pesquisas e concessão de financiamentos. Basta imaginar que as universidades públicas federais, que no Brasil possuem grande potencial de realização de pesquisas, podem ser condicionadas pelo Governo Federal, como condição para recebimento de mais recursos para pesquisas, a adotarem determinadas formas contratuais que induzam parcerias no sentido desejado pela política nacional de inovação. Rapidamente, as universidades poderão adaptar as regras contratuais que regem suas parcerias, e a partir daí o Governo Federal poderá induzir, através de mecanismos contratuais, os rumos das pesquisas no país. Sobressai desse contexto o contrato como instrumento regulatório das políticas de inovação. Observa-se, dessa forma, o papel de destaque dos instrumentos de direito privado, em especial do contrato, que a um só tempo atingem duas finalidades importantes do processo de inovação: de um lado, conferem às partes, através do maior exercício da autonomia da vontade, a possibilidade criativa de formar novas parcerias, com flexibilidade para constituição de diversos arranjos, aliada à celeridade de constituição de negócios exigida pelos parceiros privados; do outro, dão à Administração instrumento novo de alocação de recursos em pesquisas cujas regras poderão servir de instrumentos para induzir atores privados à constituição de novos mercados, segundo os critérios da política nacional de inovação, sem prejudicar sua maior liberdade e das universidades e demais centros de pesquisa para gerirem com autonomia seu processo de inovação. 
Identificadas as caraterísticas básicas do regime jurídico de contratações e demais negócios administrativos em CT\&I, podemos sintetizá-las no seguinte quadro, em contraposição ao regime geral de contratações administrativas:

\begin{tabular}{|c|c|c|}
\hline & $\begin{array}{l}\text { REGIME JURÍDICO-ADMINISTRATIVO } \\
\text { GERAL DE CONTRATAÇÕES PÚBLICAS }\end{array}$ & $\begin{array}{lr}\text { REGIME } & \text { JURÍDICO- } \\
\text { ADMINISTRATIVO } & \text { DE } \\
\text { CONTRATAÇÕES E NEGÓCIOS EM } \\
\text { CT\&I }\end{array}$ \\
\hline $\begin{array}{l}\text { REALIZAÇÃO DE LICITAÇÃO } \\
\text { E DEMAIS PROCEDIMENTOS } \\
\text { SELETIVOS }\end{array}$ & OBRIGATÓRIO EM REGRA & NÃO OBRIGATÓRIO \\
\hline $\begin{array}{l}\text { AUTONOMIA DOS ENTES E } \\
\text { ORGÃOS PÚBLICOS }\end{array}$ & MENOR & MAIOR \\
\hline OBJETO & $\begin{array}{lrr}\text { IMPOSSIBILIDADE } & \text { DE } & \text { ALTERAÇÃO } \\
\text { (VINCULAÇÃO } & \text { AO } & \text { INSTRUMENTO } \\
\text { CONVOCATÓRIO) } & & \\
& & \end{array}$ & $\begin{array}{l}\text { POSSIBILIDADE } \text { DE ALTERAÇÃO } \\
\text { MOTIVADA EM DECORRÊNCIA DE } \\
\text { INCERTEZA TECNOLÓGICA }\end{array}$ \\
\hline CONTROLE & $\begin{array}{llll}\text { BUROCRÁTICO } & \text { E } & \text { DE } & \text { PROCEDIMENTOS } \\
\text { RÍGIDOS } & & & \end{array}$ & SIMPLIFICADO E DE RESULTADOS \\
\hline GESTÃO DE BENS PÚBLICOS & $\begin{array}{l}\text { RÍGIDO E MAIS RESTRITIVO AO USO E } \\
\text { COMPARTILHAMENTO COM AGENTES } \\
\text { PRIVADOS }\end{array}$ & $\begin{array}{lllrr}\text { FLEXÍVEL E PERMITE O USO E } & \text { E } \\
\text { COMPARTILHAMENTO } & & \text { COM } \\
\text { AGENTES PRIVADOS NAS PESQUISAS }\end{array}$ \\
\hline $\begin{array}{l}\text { FONTE NORMATIVA } \\
\text { PRINCIPAL }\end{array}$ & $\begin{array}{l}\text { LEI, DECRETOS } \\
\text { NORMATIVAS }\end{array}$ & $\begin{array}{l}\text { CONTRATOS (INSTRUMENTOS } \\
\text { DIREITO PRIVADO EM GERAL) }\end{array}$ \\
\hline
\end{tabular}

A identificação dessas características dos contratos e demais negócios administrativos em CT\&I é importante para orientar a interpretação e aplicação de modo próprio das normas que formam essas instituições jurídicas, desvinculadas do funcionamento tradicional dos contratos administrativos, que não servem para as pesquisas científicas e de inovação tecnológica em razão de sua rigidez e incapacidade de adaptação célere para atender às necessidades das pesquisa e atores do ecossistema de inovação. Serve ainda para ajudar a consolidar um microssistema jurídico-administrativo específico, com cânones próprios de funcionamento, mesmo quando envolva órgãos e entidades da Administração Pública que em outras funções, distintas da CT\&I, submetem-se ao regime jurídico-administrativo geral, pois o que está em jogo é a necessidade de conferir segurança jurídica a um objeto específico que demanda normas customizadas e abertas a alterações constantes para fazer frente às mutações de sua conjuntura fática. Dessa forma, independentemente do estado da arte do direito positivo no país, com avanços e retrocessos, novidades e ortodoxias nas leis que regulam as parcerias público-privadas em inovação, o importante é definir princípios e postulados gerais 
que tornem bem claras as instituições jurídicas que regulam essas parcerias enquanto fatos da realidade, para que juristas, formuladores de políticas públicas e atores do ecossistema de inovação possam formar as diversas relações jurídicas em CT\&I com segurança, estabilidade e adequação ao objeto empírico envolvido.

\section{3 - A Lei de Inovação brasileira e o regime jurídico-administrativo das parcerias público-privadas em ciência, tecnologia e inovação}

Identificadas as características gerais que deve apresentar o regime jurídicoadministrativo das parcerias público-privadas em inovação, o passo seguinte é analisar se o direito positivo brasileiro as acolhe em suas disposições. Com esse escopo, abordaremos a Lei no 10.973 , de 2 de dezembro de 2004, conhecida como Lei de Inovação, por ser o principal diploma legislativo voltado para a formação de tais parcerias no ecossistema de inovação do Brasil.

Com efeito, desde o início dos anos 2000 têm surgido no direito brasileiro diplomas legislativos voltados para a inovação, com o objetivo de fomentar e desenvolver o ecossistema de inovação nacional, a exemplo da Lei n- 10.168, de 29 de dezembro de 2000, que criou o Programa de Estímulo à Interação Universidade-Empresa para o Apoio à Inovação e a contribuição de intervenção no domínio econômico específica para seu financiamento. Em 21 de novembro de 2005, a Lei n- 11.196 (Lei do Bem) criou incentivos fiscais à inovação tecnológica, no escopo de estimular empresas a investirem em CT\&I. Como vimos no capítulo primeiro, a maior parte dos fundos setoriais para investimento em inovação foi criado a partir dos anos 2000. Mais recentemente, a Emenda Constitucional n85, de 26 de fevereiro de 2015, incorporou novas regras à Constituição Federal, conforme abordado no capítulo segundo, visando ao objetivo maior de robustecer o sistema de inovação nacional e as parcerias público-privadas no setor.

$\mathrm{Na}$ esteira dessa paulatina e constante mutação das normas jurídicas do direito brasileiro sobre ciência, tecnologia e inovação, e especialmente após a referida Emenda Constitucional no 85, de 2015, a Lei no 13.243, de 11 de janeiro de 2016, chamada de Marco Legal da Ciência, Tecnologia e Inovação, fez uma série de alterações e acréscimos na Lei de Inovação (Lei no 10.973 , de 2004), buscando aprimorar a legislação brasileira para facilitar empreendimentos de pesquisa e desenvolvimento científico, em especial através da formação 
de parcerias entre o setor industrial e a academia e instituições públicas de pesquisa. A Lei de Inovação, com as alterações incorporadas pela Lei no 13.243 , de 11 de janeiro de 2016, é o principal estatuto legislativo de caráter nacional que rege as parcerias público-privadas em inovação no Brasil. Por essa razão, procuraremos nessa lei e em alguns pontos da Lei de Licitações (Lei no 8.666, de 1993) - alterados pela Lei no 13.243, de 11 de janeiro de 2016 - a identificação dos cânones fundamentais do regime jurídico-administrativo das parcerias em ciência, tecnologia e inovação: 1) não obrigatoriedade de licitação para formação do negócio jurídico principal e dos negócios acessórios; 2) possibilidade de mudança ou acréscimo ao objeto da parceria; 3) regras especiais para uso, compartilhamento e cessão de bens públicos; 4) controle e prestação de contas mediante procedimentos simplificados e avaliação de resultados; 5) predominância do contrato e negócios congêneres como os principais instrumentos normativos regentes dessas parcerias.

No tocante ao primeiro postulado, referente à não obrigatoriedade de licitação e demais procedimentos seletivos para a formação de empreendimentos entre atores públicos e privados, trata-se da principal regra constitutiva do regime jurídico-administrativo dessas parcerias, porque através dela os órgãos e entidades públicos terão maior autonomia para celebrar negócios jurídicos em CT\&I. A Lei de Inovação, com as alterações realizadas pela Lei no 13.243 , de 2016, traz regras claras que permitem a formação de parcerias públicoprivadas em pesquisa e desenvolvimento tecnológico sem a obrigatoriedade de licitação. Os $\operatorname{artigos} 3^{33}, 9^{34}, 19^{35}$ e $20^{36}$ apresentam as principais disposições nesse sentido.

$\mathrm{O}$ art. 3 trata do estímulo e apoio (financeiro sobretudo) dos entes da administração direta (União, Estados, Distrito Federal e Municípios) e suas agências de fomento a alianças estratégicas e projetos de cooperação envolvendo empresas, instituições

\footnotetext{
${ }^{33}$ Art. 3 - A União, os Estados, o Distrito Federal, os Municípios e as respectivas agências de fomento poderão estimular e apoiar a constituição de alianças estratégicas e o desenvolvimento de projetos de cooperação envolvendo empresas, ICTs e entidades privadas sem fins lucrativos voltados para atividades de pesquisa e desenvolvimento, que objetivem a geração de produtos, processos e serviços inovadores e a transferência e a difusão de tecnologia.

${ }^{34}$ Art. 9 - É facultado à ICT celebrar acordos de parceria com instituições públicas e privadas para realização de atividades conjuntas de pesquisa científica e tecnológica e de desenvolvimento de tecnologia, produto, serviço ou processo.

35 Art. 19 - A União, os Estados, o Distrito Federal, os Municípios, as ICTs e suas agências de fomento promoverão e incentivarão a pesquisa e o desenvolvimento de produtos, serviços e processos inovadores em empresas brasileiras e em entidades brasileiras de direito privado sem fins lucrativos, mediante a concessão de recursos financeiros, humanos, materiai s ou de infraestrutura a serem ajustados em instrumentos específicos e destinados a apoiar atividades de pesquisa, desenvolvimento e inovação, para atender às prioridades das políticas industrial e tecnológica nacional.

${ }^{36}$ Art. 20 - Os órgãos e entidades da administração pública, em matéria de interesse público, poderão contratar diretamente ICT, entidades de direito privado sem fins lucrativos ou empresas, isoladamente ou em consórcios, voltadas para atividades de pesquisa e de reconhecida capacitação tecnológica no setor, visando à realização de atividades de pesquisa, desenvolvimento e inovação que envolvam risco tecnológico, para solução de problema técnico específico ou obtenção de produto, serviço ou processo inovador.
} 
científicas, tecnológicas e de inovação ${ }^{37}$ (ICT) e entidades privadas sem fins lucrativos, quando essas alianças e projetos forem voltados para atividades de pesquisa e desenvolvimento com o objetivo de gerar produtos, processos e serviços inovadores e a transferência e a difusão de tecnologia. Nessas situações, os entes da Administração Direta e suas agências de fomento entram nas alianças e projetos como apoiadores materiais, mormente com o financiamento das pesquisas, cujas atividades serão realizadas por empresas, ICTs e entidades privadas sem fins lucrativos. O principal objetivo da norma é autorizar o financiamento às pesquisas por parte dos entes da Administração Direta e suas agências de fomento, através de apoio e estímulo às alianças e projetos que menciona.

Por sua vez, o art. 9 trata de acordos de parcerias entre ICTs e instituições públicas e privadas. Aqui, as entidades e órgãos públicos formam e realizam as parcerias com outras instituições públicas e/ou privadas, inclusive empresas, para a realização conjunta de pesquisas. São essas parcerias que poderão receber o apoio e o estímulo dos entes da Administração Direta e suas agências de fomento autorizados pelo art. 3 acima abordado.

O art. 19 prescreve o estímulo à inovação nas empresas, com base no qual União, Estados, Distrito Federal, Municípios, ICTs e suas agências de fomento poderão promover e incentivar pesquisa e desenvolvimento de produtos, serviços e processos inovadores em empresas brasileiras e entidades privadas sem fins lucrativos, através de recursos financeiros, humanos, materiais e de infraestrutura, visando, sobretudo, atender à demanda da indústria no país, conforme definido na política industrial e tecnológica nacional.

Por fim, o art. 20 é o que mais expressamente se refere à dispensa de licitação e procedimento seletivo, quando dispõe que órgãos e entidades da Administração Pública poderão contratar diretamente ICTs, entidades privadas sem fins lucrativos ou empresas, isolada ou conjuntamente, que sejam voltadas para atividades de pesquisa e de reconhecida capacitação tecnológica no setor, para a realização de atividades de pesquisa, desenvolvimento e inovação envolvendo risco tecnológico e que tenham por escopo resolver demanda técnica específica ou geração de produtos, processos ou serviços inovadores.

Esses quatro dispositivos normativos contemplam os principais arranjos jurídicos possíveis de formação e financiamento a empreendimentos conjuntos de inovação que envolvam parceiros públicos e privados:

\footnotetext{
${ }^{37}$ Art. 2o-, V - Instituição Científica, Tecnológica e de Inovação (ICT): órgão ou entidade da administração pública direta ou indireta ou pessoa jurídica de direito privado sem fins lucrativos legalmente constituída sob as leis brasileiras, com sede e foro no País, que inclua em sua missão institucional ou em seu objetivo social ou estatutário a pesquisa básica ou aplic ada de caráter científico ou tecnológico ou o desenvolvimento de novos produtos, serviços ou processos.
} 
1) Administração Pública Direta e suas agências de fomento financiando parcerias entre ICTs, empresas e entidades privadas sem fins lucrativos: ESTADO + ENTIDADES DA SOCIEDADE CIVIL, EMPRESAS E UNIVERSIDADES/INSTITUIÇÕES PÚBLICAS DE PESQUISA;

2) Acordos de parceria entre ICTs e instituições públicas e privadas: ESTADO OU UNIVERSIDADES/INSTITUIÇÕES PÚBLICAS DE PESQUISA + UNIVERSIDADES/INSTITUIÇÕES PÚBLICAS DE PESQUISA OU EMPRESAS OU ENTIDADES DA SOCIEDADE CIVIL;

3) Administração Pública Direta, ICTs e agências de fomento concedendo recursos financeiros, humanos, materiais ou de infraestrutura a empresas e entidades privadas sem fins lucrativos: ESTADO OU UNIVERSIDADES/INSTITUIÇÕES PÚBLICAS DE PESQUISA + EMPRESAS OU ENTIDADES DA SOCIEDADE CIVIL;

4) Órgãos e entidades da Administração Pública contratando diretamente ICTs, empresas ou entidades privadas sem fins lucrativos, isolada ou conjuntamente: ESTADO E/OU UNIVERSIDADES/INSTITUIÇÕES PÚBLICAS DE PESQUISA + ESTADO E/OU UNIVERSIDADES/INSTITUIÇÕES PÚBLICAS DE PESQUISA E/OU EMPRESAS E/OU ENTIDADES DA SOCIEDADE CIVIL.

Em todos esses casos, faz-se presente o cânone da não obrigatoriedade de realização de licitação ou qualquer outro procedimento de seleção para a formação da parceria entre as partes envolvidas. No caso do art. 20 da Lei de Inovação, consta no seu caput expressa disposição pela contratação direta, ou seja, sem realização de licitação. Em relação ao art. 3 da mesma lei, o art. 24, XXXI da Lei de Licitações (no 8.666, de 1993), afasta a obrigatoriedade do certame licitatório ${ }^{38}$.

As hipóteses contempladas nos arts. 9 e 19 da Lei de Inovação, embora não constem normas expressas afastando licitação e procedimentos seletivos em relação a elas, também deverão seguir a mesma regra de autonomia dos órgãos e entidades públicos para

\footnotetext{
${ }^{38}$ Comentando sobre o art. 24, XXXI da Lei no - 8.666, de 1993, Marçal Justen Filho (2012) afirma: "A Lei no 10.973 dispôs sobre os incentivos à pesquisa e à inovação e a ela se filiam diversas hipóteses de dispensa de licitação. Adotou-se fórmula ampla para a dispensa de licitações em contratações vinculadas a atividades disciplinadas pelo diploma. Em alguns ca sos, as avenças serão formalizadas por meio de convênios - e o problema da licitação não se colocará. Mas haverá casos de contratação administrativa propriamente dita. Em tais hipóteses, caberá a dispensa de licitação".
} 
escolherem diretamente seus parceiros dos empreendimentos. No caso da hipótese prevista no art. 9 - acordos de parceria entre ICTs e instituições públicas ou privadas -, a falta de menção à dispensa de licitação ou procedimento seletivo se deve ao fato de os acordos (e negócios jurídicos congêneres, como convênios) serem espécie de negócios jurídicos administrativos em que as manifestações de vontade das partes são coincidentes num mesmo objetivo, ou seja, não são contrapostas como num contrato. As partes, nessas situações, somam esforços para a realização de empreendimentos conjuntos de recíproco interesse, em que cada qual emprega seus recursos e esforços para alcançar os objetivos conjuntos. Como há soma de esforços e recursos, não se exige a realização de licitação ou procedimento seletivo, tão somente a aferição da capacidade técnica e patrimonial dos parceiros escolhidos para a realização do empreendimento conjunto. Essa hipótese de parceria público-privada em CT\&I confirma que as atividades de pesquisa e desenvolvimento científico e tecnológico fazem parte da missão institucional do Estado brasileiro, nos termos do art. 218 da Constituição Federal, razão pela qual essas parcerias não podem ser classificadas no regime jurídicoadministrativo geral das contratações públicas, inserindo-se em atividades precípuas do Estado, a permitir a maior autonomia para formação dos negócios jurídicos a elas relativos.

Quanto à hipótese do art. 19 - Administração Pública Direta, ICTs e agências de fomento, de um lado, e do outro, empresas e entidades de direito privado sem fins lucrativos -, o traço peculiar a essas parcerias é que empresas e entidades privadas, desde que brasileiras, poderão receber recursos humanos, financeiros, materiais ou de infraestrutura desde que a parceria tenha por objetivo atender às prioridades das políticas industrial e tecnológica nacional, a serem definidas em regulamento. O objetivo específico dessa forma de parceria é estimular a inovação nas empresas visando atender às demandas da indústria nacional. Em outras palavras, se for identificada empresa que realize ou pretende realizar pesquisa específica compatível com as prioridades da política industrial e tecnológica nacional, essas empresas poderão receber o suporte previsto na Lei de Inovação, dentre eles o financiamento direto (art. 19, §6-o I).

Essas hipóteses de parcerias constituem o negócio jurídico "principal” que tem por missão a realização de empreendimentos em CT\&I. Para os negócios jurídicos acessórios que visam à aquisição de bens, serviços, obras e insumos para a realização das pesquisas, também o direito positivo brasileiro previu a dispensa de licitação, no art. 24, XXI, e art. 6으, XX, ambos da Lei no 8.666, de 1993, após alteração realizada pela Lei no 13.243, de 2016 (Marco Legal da Ciência, Tecnologia e Inovação). Segundo esses dispositivos, entende-se por 
"produtos para pesquisa e desenvolvimento" os "bens, insumos, serviços e obras necessários para atividade de pesquisa científica e tecnológica, desenvolvimento de tecnologia ou inovação tecnológica, discriminados em projeto de pesquisa aprovado pela instituição contratante", cuja aquisição ou contratação pode ser realizada mediante dispensa de licitação. O objetivo dessas normas é claramente desburocratizar o fornecimento dos recursos materiais sem os quais as pesquisas não se desenvolvem. Realmente, na linha do que já havíamos apontado, não teria sentido desburocratizar a formação das parcerias e engessá-las em sua execução com a exigência das formalidades da licitação para aquisição de bens e serviços. Por essa razão, é fundamental a classificação dos negócios jurídicos em principais e acessórios, estes tendo os primeiros como fim, eis que ambos são essenciais para a formação e execução das parcerias em CT\&I, devendo estar submetidos, portanto, ao mesmo regime jurídicoadministrativo.

Nesse contexto, é de ser ressaltado que o critério identificador desses negócios jurídicos, sejam principais ou acessórios, é o fato de estarem direcionados à realização de pesquisas para desenvolvimento científico e tecnológico que gerem novos produtos, processos e serviços. É, por conseguinte, um objeto específico que os caracteriza, aliado à função dos órgãos e entidades públicos de promover, incentivar e realizar o desenvolvimento científico e tecnológico nacional, segundo as atribuições constitucionais do Estado Empreendedor brasileiro.

Para a identificação e delimitação mais precisa das atividades de pesquisa e desenvolvimento tecnológico de novos produtos, processos e serviços, as ICTs públicas deverão (a Lei de Inovação prescreve norma obrigatória) criar Núcleo de Inovação Tecnológica (NIT) próprio ou em conjunto com outras ICTs, para apoio à gestão de sua política de inovação (art. $16^{39}$ da Lei de Inovação). A norma configura notável avanço administrativo na delimitação clara, no universo das ICTs, de uma esfera de atuação direcionada à inovação e pesquisa tecnológica. Sendo constituído núcleo específico na estrutura administrativa das ICTs para a realização de atividades de pesquisa e desenvolvimento tecnológico, tornam-se mais evidentes os negócios jurídicos aos quais aplicar o regime jurídico-administrativo específico em CT\&I, bem como se permite criar especialização funcional e de gestão voltada especificamente para projetos, parcerias e pesquisas nesse setor. O NIT poderá ter personalidade jurídica própria ou não, hipótese em

\footnotetext{
${ }^{39}$ Art. 16. Para apoiar a gestão de sua política de inovação, a ICT pública deverá dispor de Núcleo de Inovação Tecnológica, próprio ou em associação com outras ICTs.
} 
que poderá ser constituído como órgão da ICT. Poderá ser constituído por uma só ICT, ou em conjunto com outras ICTs, o que ficará a critério das entidades. A possibilidade de criação conjunta de NIT por duas ou mais ICTs permite tanto a soma de esforços entre ICTs menores e com poucos recursos, quanto a formação de um NIT regional entre ICTs com proximidade geográfica. O NIT poderá ainda receber delegação para representar a ICT pública no âmbito de sua política de inovação, o que lhe confere competência para formar negócios jurídicos principais e acessórios para a realização das pesquisas, nas hipóteses previstas na Lei de Inovação. Tudo isso vem ressaltar que a atividade administrativa voltada para a promoção, incentivo e realização do desenvolvimento científico e tecnológico nacional ganha mais destaque no universo das atribuições do Estado Empreendedor brasileiro e suas entidades vinculadas, ao ponto de merecer estrutura administrativa específica que lhe confira especialização funcional e de gestão que favorecem o destaque do regime jurídicoadministrativo das parcerias em CT\&I. Inclusive, os NITs poderão, após sua implantação e consolidação, acabarem por tornar desnecessárias as fundações de apoio às quais recorrem atualmente as universidades públicas para obterem procedimentos de contratação e formação de parcerias mais céleres em comparação ao regime jurídico-administrativo das contratações públicas.

Por tudo isso, é identificado no direito positivo brasileiro, especificamente nas regras da Lei de Inovação e em pontos da Lei de Licitações, o postulado segundo o qual os negócios jurídico-administrativos em CT\&I não estão submetidos à regra da obrigatoriedade de licitação e demais procedimentos seletivos para formação das respectivas parcerias público-privadas, em fortalecimento da autonomia administrativa e liberdade contratual dos órgãos e instituições públicos com a missão de realizar o desenvolvimento científico e tecnológico nacional.

Outrossim, a Lei de Inovação contém também regras específicas para o uso, compartilhamento e cessão de bens públicos em projetos e parcerias de CT\&I. O art. 4º40 permite que laboratórios, equipamentos, instrumentos, materiais e demais instalações

\footnotetext{
${ }^{40}$ Art. 4- - A ICT pública poderá, mediante contrapartida financeira ou não financeira e por prazo determinado, nos termos de contrato ou convênio: I - compartilhar seus laboratórios, equipamentos, instrumentos, materiais e demais instalações com ICT ou empresas em ações voltadas à inovação tecnológica para consecução das atividades de incubação, sem prejuízo de sua atividade finalística; II - permitir a utilização de seus laboratórios, equipamentos, instrumentos, materiais e demais instalações existentes em suas próprias dependências por ICT, empresas ou pessoas físicas voltadas a atividades de pesquisa, desenvolvimento e inovação, desde que tal permissão não interfira diretamente em sua atividade-fim nem com ela conflite; III - permitir o uso de seu capital intelectual em projetos de pesquisa, desenvolvimento e inovação. Parágrafo único - O compartilhamento e a permissão de que tratam os incisos I e II do caput obedecerão às prioridades, aos critérios e aos requisitos aprovados e divulgados pela ICT pública, observadas as respectivas disponibilidades e assegurada a igualdade de oportunidades a empresas e demais organizações interessadas.
} 
existentes nas dependências das ICTs sejam compartilhados e utilizados por outras ICTs, empresas e até mesmo pessoas físicas em atividades de pesquisa, desenvolvimento e inovação. Dessa forma, bens móveis e imóveis (laboratórios e instalações) estarão à disposição das parcerias público-privadas. O compartilhamento e o uso desses bens serão estabelecidos em contrato ou convênio, os quais por si sós terão eficácia jurídica incidente sobre a gestão desse patrimônio, que deverá estar submetido às prioridades, critérios e requisitos aprovados pela ICT pública. Além desses bens materiais, a Lei de Inovação permite que o capital intelectual (bem imaterial) das ICTs seja compartilhado com os parceiros nas pesquisas, entendendo-se por capital intelectual, nos termos da própria Lei de Inovação (art. 2º, XIV), o "conhecimento acumulado pelo pessoal da organização, passível de aplicação em projetos de pesquisa, desenvolvimento e inovação". Aqui o objetivo é semear no ecossistema de inovação, através das parcerias com atores públicos e privados, os conhecimentos aplicáveis às pesquisas, como reconhecimento de que deve haver intercâmbio de expertise entre os seus atores para florescimento das pesquisas no país.

A Lei de Inovação ainda prevê, no art. 3--B, §2º , a cessão de imóveis pela União, Estados, Distrito Federal, Municípios, respectivas agências de fomento e ICTs públicas para a instalação e consolidação de ambientes promotores da inovação como parques $^{41}$ e polos $^{42}$ tecnológicos e incubadoras ${ }^{43}$ de empresas. As cessões serão feitas diretamente a empresas e ICTs ou através de entidades sem fins lucrativos que tenham por missão institucional a gestão de parques e polos tecnológicos e de incubadoras de empresas. $\mathrm{O}$ objetivo dessas cessões de bens imóveis públicos é o estímulo à formação de ambientes especializados e cooperativos à inovação.

Ademais, em busca de identificar na Lei de Inovação brasileira os cânones fundamentais do regime jurídico-administrativo específico para as parcerias público-privadas em ciência, tecnologia e inovação, encontram-se também normas que tratam do controle e prestação de contas mediante procedimentos simplificados e por avaliação de resultados. Logo nos princípios gerais da lei, consta a "simplificação de procedimentos para gestão de

\footnotetext{
${ }^{41}$ Art. 2o, X - parque tecnológico: complexo planejado de desenvolvimento empresarial e tecnológico, promotor da cultura de inovação, da competitividade industrial, da capacitação empresarial e da promoção de sinergias em atividades de pesquisa científica, de desenvolvimento tecnológico e de inovação, entre empresas e uma ou mais ICTs, com ou sem vínculo entre si;

${ }^{42}$ Art. 20-, XI - polo tecnológico: ambiente industrial e tecnológico caracterizado pela presença dominante de micro, pequenas e médias empresas com áreas correlatas de atuação em determinado espaço geográfico, com vínculos operacionais com ICT, recursos humanos, laboratórios e equipamentos organizados e com predisposição ao intercâmbio entre os entes envolvidos para consolidação, marketing e comercialização de novas tecnologias;

43 Art. 2º, III-A - incubadora de empresas: organização ou estrutura que objetiva estimular ou prestar apoio logístico, gerencial e tecnológico ao empreendedorismo inovador e intensivo em conhecimento, com o objetivo de facilitar a criação e o desenvolvimento de empresas que tenham como diferencial a realização de atividades voltadas à inovação;
} 
projetos de ciência, tecnologia e inovação e adoção de controle por resultados em sua avaliação $^{44 "}$. Ao final da Lei, consta previsão segundo a qual a mesma regra deverá ser aplicada a todo o disposto no diploma legal, do que se depreende que em todos os contratos, convênios e demais negócios jurídicos firmados com o objetivo de pesquisa científica e desenvolvimento tecnológico para inovação de produtos, serviços e processos se deverá adotar procedimentos simplificados e desburocratizados de controle e prestação de contas, inclusive na comprovação da aplicação de recursos públicos repassados. Do que não se pode abrir mão é da adoção de mecanismos de controle eficazes e capazes de mapear toda a aplicação dos recursos, a fim de evitar desvios e malversação. Os princípios da transparência e ampla sindicabilidade da gestão das parcerias continuam inafastáveis. $\mathrm{O}$ art. 70 da Constituição Federal ${ }^{45}$ não poderia deixar de produzir efeitos sobre essas parcerias, de modo que deverá ser realizada a fiscalização contábil, financeira, orçamentária, operacional e patrimonial, sob os aspectos da legalidade, legitimidade, economicidade, aplicação das subvenções e renúncia de receitas, ao que se submete qualquer pessoa física ou jurídica, pública ou privada, que participe dessas parcerias. $O$ objetivo, quando se fala em simplificação do controle por procedimentos, é a adoção de mecanismos mais céleres e desburocratizados de transparência e prestação de contas. A Lei de Inovação ${ }^{46}$, nesse sentido, também aponta a preferência (sem obrigatoriedade) pelo emprego de recursos da tecnologia da informação para registro e envio eletrônico das informações, com o que se pretende que as atividades de prestação de contas e controle não atrapalhem o fluxo de realização das pesquisas.

Também prescrita na Lei de Inovação, a avaliação por resultados não é uma forma alternativa de controle em relação à prestação de contas, mas sim complementar. Mostra-se adequada aos projetos e pesquisas em CT\&I porque aqui se está perseguindo a realização de algo novo (inovação), em que a possibilidade de sucesso é incerta. Diferentemente dos contratos administrativos em geral, cujo objeto é sabido e o sucesso do contrato pode ser aferido com a prestação do serviço ou a entrega da obra ou produto, nas

\footnotetext{
${ }^{44}$ Art. 1o, parágrafo único, XII.

45 Art. 70, CF - A fiscalização contábil, financeira, orçamentária, operacional e patrimonial da União e das entidades da administração direta e indireta, quanto à legalidade, legitimidade, economicidade, aplicação das subvenções e renúncia de receitas, será exercida pelo Congresso Nacional, mediante controle externo, e pelo sistema de controle interno de cada Poder. Parágrafo único - Prestará contas qualquer pessoa física ou jurídica, pública ou privada, que utilize, arrecade, guarde, gerencie ou administre dinheiros, bens e valores públicos ou pelos quais a União responda, ou que, em nome desta, assuma obrigações de natureza pecuniária.

46 Art. 27-A. Os procedimentos de prestação de contas dos recursos repassados com base nesta Lei deverão seguir formas simplificadas e uniformizadas e, de forma a garantir a governança e a transparência das informações, ser realizados anualmente, preferencialmente, mediante envio eletrônico de informações, nos termos de regulamento.
} 
parcerias para desenvolvimento de inovação não se tem garantia da consecução do objetivo final, nem quanto tempo e recursos serão empregados. Por essa razão, é pertinente a criação de mecanismos de aferição da evolução dos trabalhos, como forma de tentar mensurar a viabilidade técnica de continuação do empreendimento, de correção de rumos, para fazer prognósticos de tempo e orçamento, enfim, avaliar se os resultados estão chegando, ainda que parciais, e se eles são indicativos da possibilidade de sucesso, mesmo no longo prazo.

No direito brasileiro, um exemplo de avaliação por resultados (ou de desempenho) está nas organizações sociais, criadas com a Lei no 9.637, de 15 de maio de 1998, que expressamente prescreve, em relação aos contratos de gestão dessas entidades, a “(...) estipulação das metas a serem atingidas e os respectivos prazos de execução, bem como previsão expressa dos critérios objetivos de avaliação de desempenho a serem utilizados, mediante indicadores de qualidade e produtividade ${ }^{47}$ ". Segundo o Caderno Mare no 2 (1998), do então Ministério da Administração e Reforma do Estado - MARE, a avaliação de resultados depende da definição de objetivos estratégicos, que "são resultados de dimensão mais geral pretendidos pela instituição", e de metas de desempenho, "ações mais concretas e objetivas, necessárias ao atingimento dos objetivos estratégicos e que vão constituir a matériaprima da avaliação (e mensuração) do desempenho institucional”. Simultaneamente, deve-se estabelecer indicadores de desempenho, entendidos como elementos concretos, compatíveis com os objetivos e metas estabelecidos, que servirão para aferir o grau de realização destes últimos. O estabelecimento dos indicadores fica a critério das partes, conforme os elementos que considerem importantes dentro do projeto, desde que adequados para medir o grau de consecução dos objetivos e metas e capazes de fornecer elementos aferíveis do sucesso do empreendimento. A avaliação de resultados, portanto, consiste na "comparação dos resultados alcançados (descritos pelos indicadores de desempenho) com o desempenho pretendido (descrito pelos objetivos estratégicos e metas definidas)" (MARE, 1998).

Em relação à predominância do contrato e demais arranjos de direito privado como os principais instrumentos normativos regentes dos negócios jurídicos em inovação, observa-se na Lei de Inovação que não só na formação das parcerias, mas também em diversas questões essenciais, deixa-se abertura para o exercício da liberdade contratual por

\footnotetext{
${ }^{47}$ Lei n- 9.637, de 15 de maio de 1998, Art. 7o - Na elaboração do contrato de gestão, devem ser observados os princípios da legalidade, impessoalidade, moralidade, publicidade, economicidade e, também, os seguintes preceitos: I - especificação do programa de trabalho proposto pela organização social, a estipulação das metas a serem atingidas e os respectivos prazos de execução, bem como previsão expressa dos critérios objetivos de avaliação de desempenho a serem utilizados, mediante indicadores de qualidade e produtividade;
} 
meio da qual as partes exerçam autorregramento e possam criar vários tipos de negócios jurídicos. Questões como uso e compartilhamento de bens públicos (art. 4º , I e II), uso de capital intelectual (art. 4º , III), cláusula de exclusividade em contratos de transferência de tecnologia (art. 6-, §1ㅇ-A), estabelecimento da titularidade da propriedade intelectual e a participação nos resultados da exploração das criações resultantes da parceria (art. 9oㅡㄹ §2º) e previsão de recursos para cobertura de despesas operacionais e administrativas (art. 10) são pontos importantes das parcerias que expressamente a lei deixa para as partes estabelecerem em seus negócios jurídicos. Constata-se, dessa forma, que nas parcerias envolvendo CT\&I está nos contratos, convênios e instrumentos congêneres a principal fonte normativa que rege esses negócios jurídicos, ao contrário do regime jurídico-administrativo geral das contratações públicas, em que a lei impõe uma série de normas vinculantes limitadoras da autonomia da vontade das partes.

A colocação dos contratos e convênios como o principal centro normativo dessas parcerias concede a possibilidade de criação de múltiplos arranjos jurídicos entre os atores públicos e privados do ecossistema de inovação, o que abre a possibilidade de aumento das interações entre as partes. A maior liberdade para constituição de novos arranjos contratuais confere às parcerias flexibilidade jurídica para atender às novas demandas das pesquisas e aos diversos interesses das partes. Confere ainda a agilidade que os negócios em CT\&I necessitam para a realização das pesquisas. Além das características da liberdade, flexibilidade e celeridade, os contratos apresentam a virtude de servirem como instrumentos maleáveis face às diretrizes da política nacional de inovação, que poderá, através das ICTs públicas em especial, oferecer mais incentivos para pesquisas em determinados setores da indústria, o que poderá ser facilmente adaptado nos contratos. Por meio das ICTs e através dos contratos, o Estado poderá estimular e influir no setor privado que pretenda formar parcerias com órgãos e entidades públicas, visando atingir determinados objetivos da política nacional de inovação, como a criação ou fortalecimento de mercados específicos (outro pressuposto conceitual do Estado Empreendedor).

$\mathrm{Na}$ esteira desse argumento, observa-se que o art. 15-A ${ }^{48}$ da Lei de Inovação prescreve que as ICTs públicas deverão instituir sua política de inovação conforme "as prioridades da política nacional de ciência, tecnologia e inovação e com a política industrial e tecnológica nacional". O objetivo é estabelecer vínculo entre o governo central do Estado

\footnotetext{
${ }^{48}$ Art. 15-A. A ICT de direito público deverá instituir sua política de inovação, dispondo sobre a organização e a gestão dos processos que orientam a transferência de tecnologia e a geração de inovação no ambiente produtivo, em consonância com as prioridades da política nacional de ciência, tecnologia e inovação e com a política industrial e tecnológica nacional .
} 
Empreendedor (Ministérios, por exemplo) e ICTs e, através destas, com o setor produtivo mediante as parcerias público-privadas formadas. Como as ICTs deverão afinar sua política de inovação às prioridades e objetivos da política nacional, as parcerias com o setor produtivo reproduzirão, espera-se, as metas da política nacional. Nesse contexto, as disposições contratuais das parcerias refletirão os incentivos e estímulos do Estado Empreendedor, tornando contratos e demais formas de parcerias, de certa maneira, em instrumentos da política de inovação nacional, por serem um dos canais por meio dos quais se pode influenciar comportamentos público-privados e moldar mercados. É nesse sentido que Paulo Todescan Lessa Mattos (2009) fala em "regulação por contrato", que significa, segundo o autor, a utilização de instrumentos de direito privado em substituição aos mecanismos tradicionais de intervenção do Estado sobre os âmbitos social e econômico. Na verdade, o que se tem é o contrato como instrumento flexível de transmissão da regulação estatal sobre os atores do ecossistema de inovação, notadamente através de mecanismos promocionais como financiamentos, bens e incentivos à formação de parcerias em CT\&I.

Por fim, o último dos cinco cânones apontados do regime jurídico-administrativo das parcerias público-privadas em inovação - possibilidade de mudança ou acréscimo ao objeto das pesquisas -, embora não esteja expressamente previsto na Lei de Inovação, não deixa de ser aplicável aos negócios jurídicos prescritos na mesma, por consequência da própria liberdade contratual que marca essas parcerias. Se as partes podem formar novos arranjos contratuais e dispor sobre questões essenciais das parcerias, consequentemente poderão readequar o objeto contratual em razão de fatos técnicos imprevisíveis que apontem novos rumos para as pesquisas e/ou mostrem a inviabilidade dos objetivos inicialmente traçados. Certamente, para realinhar as pesquisas será necessária fundamentação técnica adequada que demonstre objetivamente as razões da mudança, com o fim de atender aos princípios da motivação administrativa e da transparência e às exigências de controle e prestação de contas.

\section{4 - Conclusão do capítulo}

A partir da análise da Lei de Inovação, pode-se constatar que o direito positivo brasileiro apresenta normas específicas para os negócios jurídicos e parcerias públicoprivadas em CT\&I, a autorizar a afirmação de que há um regime jurídico-administrativo 
específico para essas parcerias, destacado das demais contratações do Poder Público, normas cuja modelagem visa atender às necessidades e características específicas das pesquisas, como flexibilidade dos arranjos jurídico-contratuais, celeridade na formação de novos empreendimentos e desburocratização no relacionamento entre os atores públicos e privados.

Cumpre, portanto, dar destaque tanto às características das pesquisas científicas enquanto objeto juridicamente regulado, quanto aos cânones do regime jurídicoadministrativo próprio das parcerias em CT\&I, a fim de consolidar um microssistema jurídico-administrativo específico e delimitado que resulte em interpretação e aplicação adequadas por juristas, formuladores de políticas públicas e atores do ecossistema de inovação. 


\section{CAPÍtUlO 4 - OS CONVÊNIOS DE EDUCAÇÃO, CIÊNCIA, TECNOLOGIA E INOVAÇÃO}

Conforme abordado no capítulo anterior, o direito é elemento fundamental para o desenvolvimento do ecossistema de inovação nacional, porque o marco regulatório das relações jurídicas entre atores públicos e privados poderá facilitar e estimular a formação dessas parcerias, ou criar óbices burocráticos que as desestimulem. Em relação ao ecossistema de inovação, o direito poderá servir de ferramenta aplicada para superar pontos fracos e buscar seu desenvolvimento através dos pontos fortes ${ }^{49}$.

Interessa-nos aqui, como já ficou claro, o segmento do ecossistema de inovação nacional que abrange as relações entre atores públicos e privados, e como o direito poderá viabilizar essas parcerias de forma desburocratizada, com segurança jurídica e de modo a atender às necessidades do objeto regulado, no caso a pesquisa e desenvolvimento científico e tecnológico de novos produtos, processos e serviços.

Para tanto, é essencial considerar que, no conjunto das relações público-privadas em CT\&I, as instituições públicas de pesquisa, especialmente as universidades públicas, desempenham papel fundamental nessas parcerias. Isso porque as universidades públicas, notadamente as federais, apresentam duas características marcantes: concentram grande número de pesquisadores e estão presentes em todas as unidades da federação brasileira. As universidades, além de direcionadas ao ensino, têm por missão institucional também a pesquisa, por direta previsão constitucional ${ }^{50}$. Essas características das universidades abrem a possibilidade para que contribuam largamente para o ecossistema de inovação nacional, inclusive, por consequência de sua presença em todas as regiões do país, permitindo a regionalização das pesquisas, para atendimento a demandas locais e com conhecimento mais específico das potencialidades de cada região. Com efeito, no tocante ao ecossistema de inovação brasileiro, Mazzucato e Penna (2016) apontam como um dos seus pontos fortes a infraestrutura de ciência e pesquisa existente no país, no qual se destacam, ao lado de entidades como Fiocruz, Embrapa e Petrobras, para citar algumas, também as universidades.

\footnotetext{
${ }^{49}$ Conforme abordado ao longo deste trabalho, em especial neste capítulo, são pontos fortes do ecossistema de inovação brasileiro a infraestrutura científica e de pesquisa existente no país e a difusão das universidades públicas por todas as re giões do Brasil, em especial das universidades federais. Como pontos fracos, tem-se o isolamento da academia (universidades) do setor empresarial e industrial, o ainda pequeno número de fontes e volume de financiamentos a pesquisas e a falta de uma política permanente e coerente de longo prazo para pesquisa e desenvolvimento.

$50 \mathrm{CF}$, Art. 207. As universidades gozam de autonomia didático-científica, administrativa e de gestão financeira e patrimonial, e obedecerão ao princípio de indissociabilidade entre ensino, pesquisa e extensão.
} 
Por outro lado, Mazzucato e Penna (2016) apontam o isolamento da academia em relação à sociedade e às empresas como um dos pontos fracos do ecossistema de inovação brasileiro. Esse distanciamento identificado na maior parte do funcionamento das universidades brasileiras significa que essas entidades, enquanto instituições de pesquisa, desenvolvem suas atividades sem ter como alvo a criação de inovações que atendam às necessidades da indústria e mercado nacionais, nem os problemas da sociedade como um todo. Em outras palavras, há, em sua maior parte, pesquisas sem ter como alvo específico a inovação tecnológica voltada para o mercado, que atendam às demandas da indústria nacional e gerem conhecimentos aplicados para novos produtos, processos e serviços. Essa característica das universidades brasileiras é um gargalo grave no ecossistema de inovação nacional porque tais instituições, enquanto atores públicos que concentram pesquisadores, podem ser canais de financiamento às pesquisas em todo o país ao receberem recursos das instituições públicas de financiamento, e têm o potencial de estimular os demais atores, em especial as empresas, desde que apresentem boas perspectivas de parcerias em pesquisa e desenvolvimento. Ademais, a aproximação entre as universidades, o mercado e a indústria para focar suas pesquisas na criação de produtos, processos e serviços gera benefícios também para as próprias universidades, que poderão se beneficiar da exploração comercial das inovações que desenvolverem, obtendo novas fontes de recursos que mantenham seu funcionamento de forma mais autônoma do governo central.

Nesse contexto, um dos caminhos para o desenvolvimento do ecossistema de inovação brasileiro é por meio da ativação das universidades como atores mais participativos nesse processo. É preciso fazer com que as universidades tenham mais envolvimento em pesquisa e desenvolvimento de inovações tecnológicas direcionadas à indústria nacional, ao mercado, às exportações e para oferecer soluções aos problemas da sociedade. Em outras palavras, as universidades devem se reconhecer como atores fundamentais do desenvolvimento econômico e social sustentável do país e passarem a direcionar seus esforços científicos em conjunto com a indústria e empresariado nacionais para alavancar a economia nacional. Com essa consciência, poder-se-á romper o isolamento da academia e fazer com que sua atuação seja um vetor de estímulo para a realização de projetos e parcerias entre os demais atores do ecossistema de inovação brasileiro.

Desde o início dos anos 2000, como já mencionado neste trabalho, o direito positivo brasileiro vem passando por alterações específicas voltadas para ciência, tecnologia e inovação, inclusive para aperfeiçoar as normas que regulam as parcerias público-privadas 
neste setor. A Lei de Inovação (no 10.973, de 2 de dezembro de 2004) apresentou diversas normas no sentido de viabilizar a relação entre atores públicos e privados em inovação. Mais recentemente, a Emenda Constitucional no 85, de 2015, e a Lei no 13.243, de 11 de janeiro de 2016 (Marco Legal da Ciência, Tecnologia e Inovação), implementaram mudanças mais profundas nas normas sobre as relações público-privadas em inovação, com o claro objetivo de estimular e viabilizar a formação dessas parcerias de forma mais célere e desburocratizada. Essas alterações atingem as universidades públicas ${ }^{51}$ e lhes permitem firmar parcerias com empresas mediante regras específicas e distintas daquelas que caracterizam os negócios jurídicos da Administração Pública. O direito positivo brasileiro passou por um considerável aperfeiçoamento no escopo de viabilizar parcerias entre os atores do ecossistema de inovação nacional, de modo que as universidades públicas, atualmente, já contam com instrumentos jurídicos que lhes permitem sair do isolamento em relação à indústria e ao setor empresarial nacional.

Além dessas inovações jurídicas acontecidas no direito brasileiro, outras alterações surgiram que repercutem na esfera de atuação das universidades. A Lei no 8.958, de 20 de dezembro de 1994 (Lei das Fundações de Apoio), que trata da relação entre as instituições federais de ensino superior e as fundações de apoio, foi alterada pela Lei n12.863, de 24 de setembro de 2013. Um dos decretos que regulamentam a Lei das Fundações de Apoio, após sua alteração pela Lei no 12.863, de 2013, o Decreto no 8.240, de 21 de maio de 2014, trata especificamente da formação de parcerias entre universidades federais, fundações de apoio, empresas e demais atores para o desenvolvimento de pesquisa e inovação tecnológica, regulando o convênio que formaliza essa parceria e os critérios de habilitação de empresas. O referido decreto cria os Convênios de Educação, Ciência, Tecnológica e Inovação (Convênios ECTI), na esteira do aperfeiçoamento dos instrumentos jurídicos que viabilizem a formação de parcerias entre as universidades federais e o setor produtivo nacional.

\footnotetext{
51 Abre-se a possibilidade de pesquisa empírica sobre os efeitos dessas alterações do direito positivo brasileiro sobre o comportamento das universidades públicas, especialmente sobre seus negócios jurídicos e parcerias em ciência e tecnolog ia com empresas após a Emenda Constitucional no 85, de 2015, e a Lei no 13.243, de 11 de janeiro de 2016 (Marco Legal da Ciência, Tecnologia e Inovação), com o fim de averiguar os efeitos práticos antes e depois dessas inovações jurídicas. Tal pesquisa não foi realizada neste trabalho em razão da opção metodológica de analisar as mutações do direito positivo e sua repercussão no regime jurídico das parcerias público-privadas em pesquisa e desenvolvimento sob o aspecto normativo, sem aprofundar-se sobre os efeitos práticos dessas inovações, o que poderá será objeto de pesquisas futuras. Ademais, o recente início de vigência dessas alterações no direito positivo exige maior transcurso de tempo para que se tenham dados sobre as mudanças concretas que provocaram no comportamento das universidades públicas.
} 
O objetivo deste capítulo é apontar as características e inovações trazidas com os convênios ECTI do Decreto no 8.240, de 21 de maio de 2014, e as inovações que este Decreto e a lei por ele regulamentada (Lei das Fundações de Apoio, com as alterações da Lei no 12.863, de 24 de setembro de 2013) promoveram nas organizações sociais e fundações de apoio enquanto atores do ecossistema de inovação nacional, notadamente enquanto parceiras das universidades públicas federais. Buscar-se-á identificar quais foram essas inovações jurídicas e submetê-las ao crivo crítico à luz da Lei de Inovação enquanto norma principal que dá substrato a um microssistema jurídico de ciência, tecnologia e inovação no direito positivo brasileiro.

\section{1 - Convênios de educação, ciência, tecnologia e inovação e fundações de apoio}

A Lei no 8.958 , de 20 de dezembro de 1994, que trata das fundações de apoio ${ }^{52}$, após as alterações implementadas pela Lei no 12.863, de 24 de setembro de 2013, estabeleceu hipóteses em que essas entidades privadas sem fins lucrativos poderão firmar convênios e contratos com outras entidades, públicas ou privadas, com a finalidade de dar apoio às Instituições Federais de Ensino Superior (IFES) e demais Instituições Científicas, Tecnológicas e de Inovação (ICT) em projetos de ensino, pesquisa, extensão, desenvolvimento institucional, científico e tecnológico e estímulo à inovação, inclusive na gestão administrativa e financeira necessária à execução desses projetos.

No art. 1--B, a Lei das Fundações de Apoio previu a celebração desses convênios e contratos entre as fundações de apoio e organizações sociais e entidades privadas, com a mesma finalidade de conferir apoio às IFES e ICTs. Foi com base nesse art. 1 - $-\mathrm{B}^{53}$ da referida Lei que o Decreto no 8.240, de 21 de maio de 2014, regulamentou os Convênios de Educação, Ciência, Tecnologia e Inovação (ECTI).

Antes de tudo, convém mencionar que convênios são negócios jurídicos (acordos, ajustes etc.) envolvendo órgãos ou entidades públicas ou estes e entes privados por meio dos

\footnotetext{
52 Fundações de apoio são entidades privadas sem fins lucrativos, constituídas sob a forma de fundações de direito privado, e tem como missão institucional dar apoio às Instituições Federais de Ensino Superior (IFES) em projetos de ensino, pesquisa, extensão, desenvolvimento institucional, científico e tecnológico e estímulo à inovação, inclusive na gestão administrativa e financeira necessária à execução desses projetos.

53 Art. 1--B, caput. As organizações sociais e entidades privadas poderão realizar convênios e contratos, por prazo determinado, com as fundações de apoio, com a finalidade de dar apoio às IFES e às demais ICTs, inclusive na gestão administrativa e financeira dos projetos mencionados no caput do art. 10, com a anuência expressa das instituições apoiadas.
} 
quais se perseguem objetivos de interesse público comuns a todas as partes (CARVALHO FILHO, 2015) ${ }^{54}$. O traço distintivo dos convênios em relação aos contratos é que, enquanto nos contratos os interesses das partes são opostos e cada uma busca um bem específico, nos convênios os interesses são convergentes e cada partícipe busca o mesmo que os demais, do que resulta a soma de esforços em prol de objetivo comum. Juridicamente, contudo, contratos e convênios são espécies de negócios jurídicos, ou seja, vínculos jurídicos formados entre os partícipes aos quais o direito atribui força vinculante de direitos e deveres envolvendo determinado objeto.

Os Convênios ECTI criados pelo Decreto no 8.240, de 21 de maio de 2014, em regulamentação ao art. $1^{\circ}$-B da Lei das Fundações de Apoio, são convênios multilaterais que têm como claro objetivo a formação de parcerias entre diversos atores do ecossistema de inovação e as Instituições Federais de Ensino Superior (universidades) e demais ICTs, notadamente empresas e universidades ${ }^{55}$. São convênios multilaterais porque poderão ter como partícipes, além das IFES e demais ICTs, fundações de apoio, empresas públicas, sociedades de economia mista, suas subsidiárias e controladas, entidades privadas com ou sem fins lucrativos, e organizações sociais com contrato de gestão firmado com a União (art. 3-, caput), sendo que necessariamente deverão ter a participação de, no mínimo, fundação de apoio, IFES ou demais ICTs apoiadas e um dos demais partícipes de outra natureza, uma empresa por exemplo (art. 3ำ, parágrafo único).

O objeto dos convênios ECTI pode conter tanto a finalidade de pesquisa científica, desenvolvimento tecnológico, estímulo e fomento à inovação quanto o apoio a projetos de ensino, pesquisa, extensão e desenvolvimento institucional, ou seja, não se restringe especificamente ao desenvolvimento científico e tecnológicos de novos bens, produtos e serviços, mas também a outras finalidades de interesse das IFES e ICTs. Em

\footnotetext{
54 O Decreto Federal no 6.170 , de 25 de julho de 2007, prescreve convênios como "acordo, ajuste ou qualquer outro instrumento que discipline a transferência de recursos financeiros de dotações consignadas nos Orçamentos Fiscal e da Seguridade Social da União e tenha como partícipe, de um lado, órgão ou entidade da administração pública federal, direta ou indireta, e, de outro lado, órgão ou entidade da administração pública estadual, distrital ou municipal, direta ou indireta, ou ainda, entidades privadas sem fins lucrativos, visando a execução de programa de governo, envolvendo a realização de projeto, atividade, serviço, aquisição de bens ou evento de interesse recíproco, em regime de mútua cooperação" (art. $1^{\circ}$, $§ 1^{\circ}$, I).

55 O Decreto $n^{\circ}$ 8.240, de 21 de maio de 2014, prescreve os convênios ECTI como: "convênios de educação, ciência, tecnologia e inovação - ECTI - instrumentos que tenham como partícipes Instituição Federal de Ensino Superior - IFES ou demais ICT - Instituição Científica e Tecnológica - ICT, fundações de apoio, e empresas públicas ou sociedades de economia mista, suas subsidiárias e controladas, visando às finalidades de pesquisa científica, desenvolvimento tecnológico, estímulo e fomento à inovação, e apoio a projetos de ensino, pesquisa, extensão e desenvolvimento institucional, com transferência de recursos financeiros ou não financeiros, em parceria com entidades privadas, com ou sem fins lucrativos, envolvendo a execução de projetos de interesse recíproco, podendo contar ainda com a participação de organizações sociais, que tenham contrato de gestão firmado com a União, na forma da Lei no 8.958 , de 1994”.
} 
relação ao objeto desses convênios, é interessante perceber que o Decreto no 8.240, de 2014, prevê expressamente a possibilidade de sua alteração em razão de fato imprevisível decorrente de incerteza tecnológica, como abordado no capítulo anterior em relação aos cânones do regime jurídico-administrativo das parcerias público-privadas em pesquisa e desenvolvimento tecnológico (art. 13, II).

As empresas poderão participar dos projetos nos convênios ECTI por meio de recursos financeiros, bens ou serviços, desde que economicamente mensuráveis (art. 7º). Poderão também executar as pesquisas e gerir o projeto, de acordo com o que ficar estabelecido no convênio (art. 4º). Para a celebração dos convênios ECTI as empresas deverão atender a critérios de habilitação definidos no decreto, que em geral se limitam à comprovação de regularidade jurídica, fiscal e previdenciária.

A marca principal desses convênios, contudo, é a necessária presença das fundações de apoio. Como se trata de Decreto que regulamenta a Lei das Fundações de Apoio, a presença dessas entidades é uma constante. Esse, porém, é o ponto fraco dessa modalidade de convênio. Isso porque, após as alterações da Lei de Inovação pelo Marco Legal da Ciência, Tecnologia e Inovação (Lei no 13.243, de 11 de janeiro de 2016), as ICTs, dentre as quais estão as IFES (universidades federais, por exemplo), passaram a ter um regime jurídico-administrativo mais desburocratizado para a celebração de contratos e demais negócios jurídicos com entidades privadas, sem necessidade de licitação e procedimentos seletivos, como visto no capítulo anterior. As ICTs deverão também constituir Núcleo de Inovação Tecnológica (NIT) em sua estrutura administrativa para tratar especificamente de sua política de inovação. Em outras palavras, as ICTs, em relação às suas atividades voltadas à ciência, tecnologia e inovação, possuem regime jurídico-administrativo diferenciado que lhes confere maior celeridade e autonomia da vontade para a celebração de negócios jurídicos que tenham como objeto projetos de pesquisa e desenvolvimento científico e tecnológico. Isso torna desnecessária a presença das fundações de apoio, que têm como uma de suas principais funções oferecer às entidades apoiadas (IFES e ICTs) formas mais desburocratizadas de relacionamento jurídico.

Como demonstra Maria Sylvia Zanella Di Pietro (2012), as fundações de apoio têm sido marcadas pela característica de fornecerem às instituições públicas que apoiam a possibilidade de realizarem uma espécie de "fuga" do regime jurídico-administrativo ao qual se submetem os órgãos e entidades da Administração Pública. Isso porque, ao firmarem convênios com as entidades apoiadas, as fundações de apoio passam a ser o canal por meio do 
qual se contratam bens e serviços e pessoal para a realização de atividades direcionadas às IFES e demais ICTs nos projetos envolvidos nas parcerias. A par de uma enorme gama de problemas jurídicos e administrativos que ao longo do tempo vêm sendo imputados às fundações de $\operatorname{apoio}^{56}$, o fato é que essas instituições, com sérios questionamentos de legalidade, oferecem a possibilidade de que órgãos e entidades públicos com quem formam parceria encontrem meios mais desburocratizados de contratação de bens e serviços, inclusive para seus projetos de pesquisa e desenvolvimento, dado que através das fundações de apoio podem lançar mão do regime jurídico de direito privado que dispensa, por exemplo, o procedimento licitatório. Em outras palavras, ao celebrar convênios com as fundações de apoio, IFES e ICTs passam a contratar através dessas entidades bens e serviços para os projetos envolvidos na parceria firmada, mediante seu regime de direito privado, de forma mais fácil em relação ao regime jurídico-administrativo ao qual estão, como entidades públicas, submetidas.

Nessa esteira, como já foi mencionado acima, a Lei de Inovação, com as alterações realizadas pelo Marco Legal da Ciência, Tecnologia e Inovação, prescreve a obrigatoriedade de criação de Núcleo de Inovação Tecnológica nas ICTs para a gestão da política de inovação da entidade, sendo possível a delegação da representação da ICT pública, no âmbito de sua política de inovação, ao gestor do Núcleo ${ }^{57}$. Isso permite que no âmbito das IFES e demais ICTs haja uma esfera de atuação jurídico-administrativa regida pelas regras específicas dos negócios em ciência, tecnologia e inovação, conforme abordado no capítulo anterior. Ora, se esse regime jurídico diferenciado contém as características exigidas pelas atividades de pesquisa e desenvolvimento, aptas à celebração de negócios jurídicos principais e acessórios de forma desburocratizada e semelhante ao regime de direito privado, por consequência deixa de ser necessária a celebração de convênios com fundações de apoio para a "fuga" do regime jurídico-administrativo, dado que a construção de um regime jurídicoadministrativo próprio para as contratações e convênios em CT\&I capacita (juridicamente) IFES e ICTs para o melhor relacionamento jurídico com atores privados do ecossistema de inovação.

Tal situação demonstra que a Lei de Inovação vem se consolidando como a norma estruturante de um microssistema jurídico voltado para as contratações e negócios jurídicos da Administração Pública em pesquisa e desenvolvimento tecnológico. As alterações

\footnotetext{
${ }^{56}$ Ver, por exemplo, o Acórdão no 2.731/2008 do Tribunal de Contas da União.

${ }^{57}$ Art. 16 da Lei n- 10.973, de 2 de dezembro de 2004.
} 
realizadas na Lei de Inovação pelo Marco Legal da Ciência, Tecnologia e Inovação foram posteriores às alterações da Lei das Fundações de Apoio e à sua regulamentação pelo Decreto no 8.240, de 21 de maio de 2014, que criou os Convênios ECTI. Comparada com a Lei de Inovação, a referida espécie de convênio, embora tenha o objetivo de aproximar, no ecossistema de inovação brasileiro, a academia (universidades) do setor empresarial, já se encontra ultrapassada pelo novo regime de contratações estabelecido com o Marco Legal da Ciência, Tecnologia e Inovação, porque este confere maior autonomia às IFES e ICTs na realização de suas atividades de pesquisa e desenvolvimento, tornando desnecessária a presença das fundações de apoio em razão dos Núcleos de Inovação Tecnológica, que dispensam o suporte jurídico oferecido por aquelas entidades.

\section{2 - Convênios de educação, ciência, tecnologia e inovação e organizações sociais}

Organização social é uma qualificação jurídica concedida à entidade privada sem fins lucrativos que atua nas áreas de ensino, pesquisa científica, desenvolvimento tecnológico, proteção e preservação do meio ambiente, cultura ou saúde, qualificação com a qual estará a entidade privada habilitada a celebrar contrato de gestão com o Poder Público para o desenvolvimento de atividades nas respectivas áreas de atuação, podendo receber, em razão desse contrato, recursos orçamentários, bens e servidores públicos cedidos (FERREIRA DA ROCHA, 2006).

Trata-se de forma de parceria criada no direito brasileiro na reforma administrativa da década de 1990 pela Lei no 9.637, de 15 de maio 1998. Seu objetivo é instaurar modalidade de parceria com a sociedade civil organizada para a realização de atividades sociais de interesse público. Segundo o Plano Diretor da Reforma do Aparelho do Estado (MARE, 1998), o objetivo é transferir para as organizações sociais atividades públicas não estatais, assim consideradas aquelas que atendem ao interesse público, mas não são realizadas exclusivamente pelo Estado, a quem caberia apenas realizar as atividades típicas e exclusivas de Estado (atividade judicial, poder de polícia, tributação, dentre outras). Às organizações sociais caberia a realização de atividades que, na perspectiva do citado Plano Diretor, seriam melhor realizadas pela sociedade civil organizada, de forma a diminuir o tamanho do Estado em áreas em que não precisaria atuar, contribuindo dessa maneira para a redução do aparelho estatal, medida imprescindível, segundo a lógica da citada reforma administrativa, para superar a crise fiscal e obter ganhos de eficiência nos serviços públicos. 
O vínculo de uma organização social como o Poder Público é mais profundo que o das demais entidades privadas parceiras. Mediante contrato de gestão, a entidade qualificada como organização social passa a receber diretamente recursos orçamentários para fomento das atividades pactuadas, podendo receber bens e servidores públicos cedidos com a mesma finalidade de fomento. Além disso, membros do conselho de administração da organização social são indicados pelo Poder Público contratante, de maneira que o Estado se faz presente no órgão máximo da entidade privada, cujo estatuto social deve ser reformado para atender às imposições da Lei 9.637/1998, condição prévia para a qualificação como organização social.

O fomento das organizações sociais é aquele que o Estado presta à entidade privada que tenha esta qualificação, ou seja, o apoio financeiro e recursos (bens e servidores) que o Estado concede às organizações sociais para que prestem os serviços que lhes foram transferidos via contrato de gestão. Não se trata de fomento das organizações sociais para atividades realizadas por terceiros. A distinção se baseia na classificação realizada pelo Plano Diretor da Reforma do Aparelho do Estado, segundo o qual, existem atividades públicas não estatais, que, embora sejam de interesse público, podem ser realizadas por entes da esfera privada, e atividades exclusivas de Estado, que não podem ser exercidas por pessoas de direito privado. Na concepção do referido Plano Diretor, a atividade de fomento é exclusiva e típica de Estado, de modo que não poderia ser realizada pelas organizações sociais.

Por fomento público entende-se a atividade pela qual o Estado estimula comportamentos desejados, geralmente concedendo algum incentivo (prêmio) ou retirando obstáculos (tributários, por exemplo), com o fim levar as pessoas a adotarem o comportamento pretendido que atende ao interesse público. Célia Cunha Mello (2003) afirma que atualmente o fomento é compreendido como a função administrativa por meio da qual o Estado, atuando sem compulsoriedade, promove determinado objeto para realizar indiretamente necessidades públicas.

O fomento do Estado para a organização social com a qual mantém contrato de gestão é realizado através de recursos públicos, bens e servidores cedidos, de modo que sejam empregados em atividades públicas não estatais realizadas pela própria organização social, por meio das quais as necessidades públicas sejam atendidas.

O contrato de gestão é o negócio jurídico em que são firmados os termos das atividades a serem desenvolvidas pela organização social, definindo-se as metas e indicadores de desempenho e avaliação, bem como o fomento do Poder Público contratante para as atividades da organização social. O contrato de gestão opera mediante a lógica de resultados, 
no qual o controle não é prévio e de procedimentos, mas sim focado nas metas alcançadas (resultados). Por essa razão, o núcleo fundamental do contrato de gestão são os objetivos e metas traçados para as atividades da organização social, cujo papel não deve ser o de uma mera prestadora de serviços para a Administração Pública, mas sim de executora de plano que visa alcançar sempre um patamar qualitativo melhor nos serviços públicos, em busca da eficiência administrativa. Em outros termos, a função da organização social através do contrato de gestão é realizar o que outrora fazia um órgão público prestador de serviços, a fim de que nessas áreas sociais haja a progressiva substituição do Estado pela sociedade civil organizada. O Estado, antes prestador do serviço público, passa a ser regulador e fomentador dos serviços a cargo das entidades privadas.

A Lei das Fundações de Apoio (no 8.958, de 20 de dezembro de 1994), com as alterações implementadas pela Lei no 12.863, de 24 de setembro de 2013, previu que as organizações sociais podem realizar convênios e contratos com outras entidades privadas (empresas, por exemplo) e fundações de apoio, com a finalidade de dar apoio às IFES e demais ICTs, inclusive na gestão administrativa e financeira dos projetos de ensino, pesquisa, extensão, desenvolvimento institucional, científico e tecnológico e estímulo à inovação (art. $\left.1^{\circ}-\mathrm{B}\right)^{58}$. Previu ainda, no parágrafo único do art. $1^{\circ}$-B, que IFES ou demais ICTs apoiadas, fundação de apoio, entidades privadas, empresas públicas ou sociedades de economia mista, suas subsidiárias ou controladas, poderão celebrar convênios com organizações sociais para finalidades de pesquisa, desenvolvimento, estímulo e fomento à inovação.

Aqui, apesar da redação um pouco confusa e da inserção da disposição normativa num parágrafo (teria sido mais adequada a alteração da própria lei das organizações sociais, Lei no 9.637/1998), criou-se a possibilidade jurídica de as organizações sociais realizarem fomento à pesquisa e desenvolvimento de inovações científicas e tecnológicas. Ou seja, inovando o regime jurídico das organizações sociais idealizado com a Reforma do Aparelho do Estado na década de 1990, que considerou a atividade de fomento exclusiva de Estado e, portanto, não transferível para as organizações sociais, a Lei no 12.863 , de 24 de setembro de

\footnotetext{
58 Art. 1--B. As organizações sociais e entidades privadas poderão realizar convênios e contratos, por prazo determinado, com as fundações de apoio, com a finalidade de dar apoio às IFES e às demais ICTs, inclusive na gestão administrativa e financeira dos projetos mencionados no caput do art. 1ำ, com a anuência expressa das instituições apoiadas.

Parágrafo único. A celebração de convênios entre a IFES ou demais ICTs apoiadas, fundação de apoio, entidades privadas, empresas públicas ou sociedades de economia mista, suas subsidiárias ou controladas, e organizações sociais, para finalidades de pesquisa, desenvolvimento, estímulo e fomento à inovação, será realizada mediante critérios de habilitação das empresas, regulamentados em ato do Poder Executivo federal, não se aplicando nesses casos a legislação federal que institui normas para licitações e contratos da administração pública para a identificação e escolha das empresas convenentes.
} 
2013, ao alterar a Lei das Fundações de Apoio, mudou o regime jurídico das organizações sociais, permitindo que, em convênios com IFES, ICTs, fundações de apoio, entidades privadas, empresas inclusive, as organizações sociais possam realizar fomento à inovação, isto é, transferir recursos (oriundos do contrato de gestão) para financiar pesquisa e desenvolvimento de inovação tecnológica. Essa mutação no regime jurídico de atuação das organizações sociais faz com que essas entidades passem a ter no rol de suas atividades, desde que previsto em contrato de gestão, o fomento à pesquisa e desenvolvimento de inovação científica e tecnológica, sendo mais um canal ou instrumento de financiamento da política de CT\&I do qual pode lançar mão o Estado Empreendedor ${ }^{59}$.

No Decreto no 8.240, de 2014, existe a previsão de participação de organizações sociais nos Convênios ECTI (art. 3\%). Como as demais entidades partícipes, as organizações sociais poderão, nos termos do art. 4ำ do decreto, exercer cumulativamente as funções de gestão, execução e financiamento parcial ou integral dos convênios conforme definido em cada instrumento. Tais disposições corroboram o entendimento aqui exposto, segundo o qual houve mudança no regime jurídico das organizações sociais para que no rol de suas atribuições esteja o fomento à pesquisa e desenvolvimento científico e tecnológico, entendido como financiamento mesmo aos projetos firmados entre as partes convenentes, de modo a superar a classificação adotada pelo Plano Diretor da Reforma do Aparelho do Estado que

\footnotetext{
59 Em 2013, a União qualificou como organização social a Associação Brasileira de Pesquisa e Inovação Industrial EMBRAPII, através do Decreto de 2 de dezembro de 2013, publicado no Diário Oficial da União de 3 de dezembro de 2013, para a finalidade de "promover e incentivar a realização de projetos empresariais de pesquisa, desenvolvimento e inovação voltados para setores industriais por meio de cooperação com instituições de pesquisa tecnológica, mediante celebração de contrato de gestão firmado com o Ministério da Ciência, Tecnologia e Inovação, na qualidade de órgão supervisor, e com o Ministério da Educação". No mesmo ano, a União celebrou contrato de gestão com essa organização social. O objetivo principal da EMBRAPII é unir instituições de pesquisa tecnológica e empresas industriais, com o escopo de criar sinergias em projetos de pesquisa e desenvolvimento de inovações tecnológicas. A EMBRAPII também tem por missão financiar parte desses projetos de formar compartilhada com os demais partícipes visando dividir os riscos e incertezas da fase précompetitiva dos projetos, a pesquisa básica. Os recursos aportados pela EMBRAPII nos projetos que seleciona são oriundos do contrato de gestão firmado com o Ministério da Ciência, Tecnologia, Inovações e Comunicações e com o Ministério da Educação. Através de suas atividades, a EMBRAPII contribui para superar dois gargalos da pesquisa e desenvolvimento brasileiro: a falta de sinergia e interação em projetos de CT\&I entre as instituições de pesquisa, em especial as universidad es, e as empresas industriais; e a ainda pequena fonte de financiamento para pesquisas nas fases de incerteza. Com a EMBRAPII, tem-se um exemplo concreto de organização social que, após a mutação realizada no regime jurídico das organizações sociais pela Lei n- 12.863, de 24 de setembro de 2013, que alterou a Lei das Fundações de Apoio (n- 8.958/1994), realiza fomento a atividades de terceiros, isto é, recebe recursos via contrato de gestão do Estado e os repassa para projetos realizados por terceiros, no caso as instituições públicas ou privadas de pesquisa tecnológica em parceria com empresas industriais em projetos de pesquisa e desenvolvimento tecnológico credenciados por ela EMBRAPII. Inovando o regime jurídico pensado para as organizações sociais no Plano Diretor da Reforma do Aparelho do Estado, tem-se uma organização social realizando fomento e o próprio fomento como atividade não mais exclusiva de Estado, ao menos quando relacionado a projetos de pesquisa e desenvolvimento científico e tecnológico. Por fim, tem-se ainda as organizações sociais como mais um instrumento jurídico do Estado Empreendedor para formação de parceria com o setor privado.
} 
colocava o fomento como atividade exclusiva de Estado e, por consequência, vedava sua transferência às organizações sociais.

Essa alteração no regime jurídico das organizações sociais não fica restrita apenas aos convênios ECTI, porque o parágrafo único do art. 1--B da Lei das Fundações de Apoio não faz essa limitação. Na prática, embora inserido na Lei das Fundações de Apoio, tal disposição normativa afeta o regime jurídico das organizações sociais (por isso nossa crítica no sentido de que tal disposição deveria ter sido inserida na própria Lei das Organizações Sociais), de modo a poderem fomentar projetos de pesquisa e desenvolvimento, com recursos do contrato de gestão, em parcerias não restritas aos convênios ECTI.

\section{3 - Conclusão do capítulo}

A principal conclusão sobre o convênio de educação, ciência, tecnologia e inovação (ECTI) previsto no Decreto no 8.240, de 21 de maio de 2014, e a Lei das Fundações de Apoio, quando analisados face à Lei de Inovação com as alterações realizadas pelo Marco Legal da Ciência, Tecnologia e Inovação, é que, de fato, a Lei de Inovação se consolida como a principal norma no direito positivo brasileiro na disciplina dos negócios jurídicos entre atores públicos e privados em pesquisa e desenvolvimento científico e tecnológico.

Isso porque, embora os convênios ECTI tenham a boa pretensão de viabilizar convênios e parcerias entre instituições públicas de pesquisa, em especial universidades federais, e o setor empresarial em projetos de PD\&I, a presença obrigatória das fundações de apoio nesses convênios os deixa um passo atrás da Lei de Inovação, se considerarmos que esta prevê a criação dos Núcleos de Inovação Tecnológica no âmbito das ICTs, com capacidade jurídica para gerir a política e os negócios em CT\&I no âmbito dessas entidades, podendo celebrar negócios jurídicos principais e acessórios com regras próprias e mais adequadas às parcerias público-privadas em PD\&I, sem as limitações do regime jurídico das contratações públicas em geral.

Foi justamente para contornar as limitações do regime jurídico dos negócios e contratações administrativas que foram criadas as fundações de apoio, as quais, com personalidade jurídica de direito privado, podem contratar bens e serviços para os projetos das entidades apoiadas (universidades públicas) de forma desburocratizada e sem necessidade de atender ao regime jurídico público de contratações. As mudanças na Lei de Inovação vindas 
com o Marco Legal da Ciência, Tecnologia e Inovação na prática tornam desnecessário o suporte jurídico prestado às IFES pelas fundações de apoio, dado que agora as próprias entidades apoiadas estarão submetidas a um regime jurídico adequado à realização de sua política e negócios em pesquisa e desenvolvimento tecnológico.

O principal ganho institucional decorrente da Lei das Fundações de Apoio e dos Convênios ECTI foi o de consolidar as organizações sociais como realizadoras de fomento a projetos de CT\&I, superando a visão de que o fomento é atividade exclusiva do Estado. As organizações sociais passam a ser, quando assim conste em contrato de gestão e apenas nas atividades de ciência, tecnologia e inovação, mais um instrumento de parceria do Estado Empreendedor com o setor privado, em especial no âmbito na Administração Pública Federal, que já consta com organização social qualificada e com contrato de gestão firmado atuando no financiamento a projetos de pesquisa e desenvolvimento tecnológico, compartilhando os riscos e incertezas das pesquisas com a iniciativa privada e contribuindo para a interação universidade-empresa em matéria de PD\&I. 


\section{CONCLUSÃO}

Este trabalho teve como objetivo identificar os pressupostos conceituais do Estado Empreendedor e analisar se a Constituição Federal do Brasil os adotou em suas disposições sobre ciência, tecnologia e inovação. A compreensão do Estado Empreendedor é essencial para lançar um olhar crítico sobre políticas industriais e de promoção ao desenvolvimento científico e tecnológico. Significa também a percepção do real papel que o Estado desempenhou e pode realizar na condução do progresso tecnológico e econômico através da inovação.

A visão econômica predominante, que exerce influência sobre a política e os meios de comunicação de massa, sustenta o afastamento do Estado dos mercados e lhe reserva apenas a função de corrigir falhas de mercado e assegurar a estrutura essencial - educação, por exemplo - para que os agentes privados realizem inovações promotoras do desenvolvimento econômico. Contudo, neste trabalho foi demonstrado que, a partir da abordagem de experiências internacionais e do próprio Brasil, ao Estado coube papel essencial na inovação tecnológica da indústria, com a consequente formação de novos mercados. O setor privado, ao contrário do que comumente se imagina, tende a se afastar de investimentos de longo prazo em inovação cujos resultados são incertos. Aqui reside a importância do Estado Empreendedor, ao assumir a função de investir em pesquisa básica e aplicada em ambientes de incerteza visando à geração de inovações que permitam o acesso a novos mercados, competitividade internacional e desenvolvimento econômico e social para o país. Demonstrou-se, ademais, que a função do Estado Empreendedor não é subsidiária à do setor privado, mas sim de condução dos rumos da inovação tecnológica segundo as necessidades da indústria nacional e as demandas sociais do país, com o escopo de promover o desenvolvimento econômico sustentável e a concretização dos direitos humanos fundamentais.

Com esses fundamentos, foram identificados quatro pressupostos conceituais do Estado Empreendedor: (1) financiador de pesquisas quando as incertezas de resultados afastam a iniciativa privada; (2) condutor e orientador do desenvolvimento do setor de ciência, tecnologia e inovação nacional; (3) a orientação da política de pesquisa, desenvolvimento e inovação para a criação de novos produtos e serviços e respectivos mercados para a economia nacional; (4) a valorização de parcerias público-privadas para o desenvolvimento da inovação nacional. Esses pressupostos autorizam a afirmação de que o 
Estado Empreendedor é uma dimensão do Estado Regulador, aquela que se volta para o setor de ciência, tecnologia e inovação. A regulação que caracteriza o Estado Regulador significa a permanente aplicação (e reaplicação, consoante a mudança conjuntural da realidade multifacetada) de instrumentos de intervenção sobre os setores econômicos e sociais para conduzi-los à realização dos direitos fundamentais. O Estado Empreendedor é, nesse contexto, parte do Estado Regulador na medida em que gerencia o setor de ciência, tecnologia e inovação, ajustando e reajustando seus instrumentos de promoção do desenvolvimento científico e tecnológico.

Identificados os pressupostos conceituais do Estado Empreendedor, demonstrouse que foram acolhidos pela Constituição Federal do Brasil, em cujas disposições são encontradas normas que dão ao Estado brasileiro a modelagem que o caracteriza como Estado Empreendedor, mormente após as alterações realizadas no capítulo constitucional da ciência, tecnologia e inovação pela Emenda Constitucional no 85, de 2015.

A compreensão de que a Constituição Federal adotou o modelo do Estado Empreendedor para o setor de ciência, tecnologia e inovação é fundamental para a orientação de políticas públicas e reformas institucionais que visem ao desenvolvimento nacional. Significa que não é possível qualquer política pública ou qualquer reforma institucional, mas tão somente aquelas que respeitem a moldura constitucional definida, dentro da qual infinitas possibilidades e arranjos institucionais são viáveis. Mais especificamente, significa que não poderão prosperar políticas públicas e reformas institucionais que adotem a retirada da regulação do Estado sobre os diversos setores e mercados, por irem contra as premissas constitucionais adotadas. Este ponto é atual e de grande importância, eis que estão em curso propostas de reformas que põem cada vez mais nas mãos do mercado de capitais, em detrimento do Estado, a função de impulsionar o desenvolvimento econômico. Este pensamento fere o pacto constitucional brasileiro, que deposita no Estado papel relevante de condutor (nos termos empregado neste trabalho) do desenvolvimento econômico sustentável. O modelo constitucional brasileiro de Estado Empreendedor é institucionalista, baseia-se nas instituições do Estado para a promoção do desenvolvimento. Não concebe que este se dê apenas pelo fortalecimento das instituições do mercado de capitais. Pelo contrário, o desenvolvimento nacional pressupõe a regulação do Estado, em atuação conjunta com o setor privado, mediante instituições que valorizem as peculiaridades nacionais e políticas públicas que visem superar deficiências do setor produtivo nacional, em especial pelo emprego da inovação. 
Paralelamente, aflora a preocupação do Estado Empreendedor com a sustentabilidade, por direta imposição constitucional. Na própria definição do modelo de Estado, ficou definido constitucionalmente que este deverá promover a sustentabilidade em suas múltiplas dimensões, para fruição estável e institucionalizada de direitos fundamentais pelas gerações do presente e as futuras. O desenvolvimento tecnológico e as inovações foram concebidos no texto constitucional como caminhos pelos quais os problemas nacionais poderão ser solucionados, cabendo ao Estado Empreendedor regular o setor de CT\&I para conduzir o processo de desenvolvimento em parceria com atores privados. É nesse contexto que o Estado Empreendedor ganha relevo e a identificação dos seus pressupostos conceituais serve de baliza para afastar políticas e reformas contrárias ao modelo constitucional brasileiro. O Estado Empreendedor tem a missão de regular o setor de CT\&I para produzir inovações que ampliem os horizontes da economia nacional, mediante políticas públicas e reformas institucionais que, adaptadas à realidade brasileira, abram novos mercados, gerem inovações e acima de tudo permitam a fruição sustentável de direitos fundamentais pela população.

Em consequência, transformações têm acontecido no direito positivo brasileiro em resposta às atribuições do Estado Empreendedor. A realidade setorial cada vez mais complexa e exigente de especialização técnica conduz à demanda por especialização da regulação jurídica. O setor de ciência, tecnologia e inovação, no qual a relação público-privada é essencial, exigiu do direito brasileiro mutações para atualização e especialização regulatória, o que culminou nas novas disposições da Lei de Inovação, em especial aquelas que tratam da maior agilidade na formação de parcerias público-privadas em pesquisa e desenvolvimento científico e tecnológico. A Lei de Inovação, com as alterações do Marco Legal da Ciência, Tecnologia e Inovação, instaura novo regime jurídico-administrativo para as contratações e demais negócios jurídicos entre atores públicos e privados que tenham como objeto projetos em $\mathrm{P} \& \mathrm{D}$ para inovação de bens, processos e serviços.

Nessa esteira, foi aprofundado o quarto pressuposto conceitual do Estado Empreendedor (valorização de parcerias público-privadas para o desenvolvimento da inovação nacional), por ser a relação público-privada em projetos de pesquisa e desenvolvimento tecnológico um dos gargalos do ecossistema de inovação brasileiro, marcado pela pouca sinergia entre instituições de pesquisa, notadamente as universidades (academia), e a indústria. Adotou-se a premissa de que o direito é elemento que importa para o ecossistema de inovação nacional, porque as relações (parcerias) entre atores públicos e privados serão necessariamente relações jurídicas. Desse modo, as normas jurídicas que 
regulam tais relações poderão facilitar e estimular a formação dessas parcerias e o florescimento dos projetos de pesquisa, ou criar entraves que os dificultam. Por essa razão, há a necessidade de um regime jurídico específico para as parcerias público-privadas em CT\&I, eis que o regime geral de contratações públicas previsto na Lei de Licitações (no 8.666, de 1993) apresenta regras inadequadas a tais parcerias, com formalidades demasiadas que engessam sua formação e execução.

A partir da análise da Lei de Inovação (Lei no 10.973, de 2004), especialmente após as alterações realizadas pelo Marco Legal da Ciência, Tecnologia e Inovação (Lei no 13.243, de 2016), sustentou-se a existência de regime jurídico-administrativo específico para as parcerias público-privadas em CT\&I. Tal regime tem as seguintes regras fundamentais: 1) não obrigatoriedade de licitação para formação do negócio jurídico principal e dos negócios acessórios que envolvam pesquisa e desenvolvimento de novos produtos, processos e serviços para o mercado; 2) possibilidade de mudança ou acréscimo ao objeto da parceria; 3) regras especiais para uso, compartilhamento e cessão de bens públicos; 4) controle e prestação de contas mediante procedimentos simplificados e avaliação de resultados; 5) predominância do contrato e negócios congêneres como os principais instrumentos normativos regentes dessas parcerias. Demonstrou-que a Lei de Inovação contém essas regras específicas (diversas do regime jurídico da Lei de Licitações) para os negócios jurídicos envolvendo atores públicos e privados em projetos de inovação, a permitir a interação entre academia e indústria de forma mais simples e célere, viabilizando financiamentos e soma de esforços para o desenvolvimento e inovações através dos mais variados arranjos contratuais que as partes necessitarem realizar com o exercício da liberdade contratual.

A Lei de Inovação contém ainda, como apontado neste trabalho, a previsão dos Núcleos de Inovação Tecnológica (NIT), a serem obrigatoriamente constituídos nas Instituições Científica, Tecnológica e de Inovação (ICT) públicas, para gestão da política de inovação dessas entidades. Esses Núcleos significam uma estrutura jurídico-administrativa específica nas ICTs públicas, que servirão para o destaque das atividades de pesquisa e desenvolvimento tecnológico em relação às demais atividades da entidade, a fim de que os negócios jurídicos em CT\&I tenham espaço institucional e gestão delimitados, com maior especialização.

É a gênese de um novo regime jurídico-administrativo para as relações do Estado Empreendedor com o setor privado em CT\&I, formado por princípios e regras próprios, voltados para atender às demandas dos projetos de pesquisa tecnológica. Novos postulados 
que deverão ser aplicados por juristas, profissionais e formuladores de políticas públicas quando tratarem dos negócios jurídicos entre atores públicos e privados envolvendo pesquisa e desenvolvimento tecnológico, afastando as regras gerais do regime público de contratações típico da Lei no 8.666, de 1993, que tantos gargalos levanta aos projetos de PD\&I. É preciso, portanto, reconhecer que o direito positivo brasileiro mudou, transformou-se na regulação setorial das parcerias público-privadas em inovação tecnológica para, a partir daí, não só aplicar tais regras de modo apropriado, como buscar sempre aperfeiçoá-las, tendo em mira uma regulação mais técnica, com segurança jurídica e desburocratizada, face à conjuntura setorial sempre em modificação.

Ao final do trabalho, foi abordado o Convênio de Educação, Ciência, Tecnologia e Inovação, criado pelo Decreto no 8.240, de 21 de maio de 2014, que regulamenta o art. 1--B da Lei no 8.958, de 20 de dezembro de 1994 (Lei das Fundações de Apoio). Esse decreto surgiu com o objetivo de aprimorar os mecanismos jurídicos para promoção da relação universidade-empresa em matéria de inovação. Ao ser feita análise crítica dessa modalidade de convênio, em especial face à Lei de Inovação, concluiu-se que esta lei deixa tais convênios um passo atrás no incremento das parcerias público-privadas em inovação, especialmente porque exigem a presença das fundações de apoio, de cujo suporte jurídico as ICTs públicas (universidades em especial), espera-se, tenderão a não necessitar mais, com a criação dos Núcleos de Inovação Tecnológica e o novo regime jurídico-administrativo das parcerias público-privadas da Lei de Inovação.

Por outro lado, a análise do Decreto no 8.240, de 21 de maio de 2014, e da Lei no 8.958, de 20 de dezembro de 1994 (Lei das Fundações de Apoio), revelou que o regime jurídico das organizações sociais foi alterado para permitir que essas entidades passem a formar parcerias em projetos de pesquisa e desenvolvimento tecnológico de produtos, processos e serviços com autorização para fomentá-los, isto é, financiar tais projetos com recursos do contrato de gestão firmado como Poder Público, compartilhando com os demais parceiros dos projetos os riscos das pesquisas. Tal fato é importante porque, quando do surgimento das organizações sociais na última década do século 20 , essas entidades foram consideradas no Plano Diretor da Reforma do Aparelho do Estado como responsáveis pela absorção das atividades públicas não estatais, ou seja, aquelas consideradas de interesse público, porém não exclusivas do Estado, e que poderiam, portanto, ser repassadas para o setor privado, neste incluídas as organizações sociais. O fomento público era considerado atividade típica e exclusiva de Estado, e como tal, não poderia ser transferido para as 
organizações sociais. Contudo, com as alterações na Lei das Fundações de Apoio realizadas pela Lei no 12.863 , de 24 de setembro de 2013, é permitido que as organizações sociais ingressem em projetos de pesquisa e desenvolvimento de produtos, processos e serviços com outros atores públicos ou privados do ecossistema de inovação para fomentar tais projetos com recursos do contrato de gestão. As organizações sociais, por conseguinte, passam a ter função a mais como instrumento do Estado Empreendedor em parcerias público-privadas envolvendo ciência, tecnologia e inovação.

Por tudo o que se apontou e concluiu neste trabalho, é preciso reconhecer que o Estado Empreendedor é uma realidade no direito positivo brasileiro, inclusive na Constituição Federal, e tem provocado alterações no direito infraconstitucional em resposta às demandas por normas jurídicas mais adequadas e especializadas para a regulação da ciência, tecnologia e inovação, em especial aquelas que tratam da formação de parceiras público-privadas no setor. Cumpre aperfeiçoar tais regras constantemente, em razão da realidade sempre mutante do mundo contemporâneo. Em especial, cumpre formatar as políticas industrial e de promoção do desenvolvimento cientifico e tecnológico para que tenham objetivos claros, coerência em seus fundamentos, persistência ao longo do tempo, articulação eficiente entre os órgãos do Estado e entre estes e o setor privado, recursos que não sejam contingenciados por políticas de ajuste fiscal, enfim, é preciso que os governos que administram o Estado Empreendedor realizem o papel que a Constituição Federal lhe reservou. Finalmente, é preciso reconhecer de uma vez por todas que a inovação tecnológica é um dos caminhos mais seguros e sólidos de desenvolvimento econômico e social sustentável para o país. Só assim o Estado Empreendedor brasileiro, através de regulação setorial consistente em CT\&I, poderá consolidar no longo prazo um ecossistema de inovação robusto e ativo no Brasil. 


\section{REFERÊNCIAS BIBLIOGRÁFICAS}

1. ARANHA, M. I. Manual de Direito Regulatório. 3- ed., London: Laccademia Publishing, 2015.

2. ARBIX, G. Inovar ou Inovar. A indústria brasileira entre o passado e o presente. São Paulo: Papagaio, 2007.

3. ARBIX, G. et al (Orgs). Inovação: Estratégia de sete países. Série Cadernos da Indústria ABDI. v. XV, Brasília: Agência Brasileira de Desenvolvimento Industrial, 2010.

4. ARBIX, G.; VARON, J. Finlândia: O salto para uma economia baseada no conhecimento. In: ARBIX, G. et al (Orgs). Inovação: Estratégia de sete países. Série Cadernos da Indústria ABDI. v. XV, Brasília: Agência Brasileira de Desenvolvimento Industrial, 2010.

5. BANDEIRA DE MELlO, C. A. Curso de Direito Administrativo. 21 a ed., São Paulo: Malheiros, 2006.

6. BOBBIO, N. Dalla struttura alla funzione. Nuovi studi di teoria del diritto. Milano: Edizioni di Comunità, 1977.

7. BRASIL. Ministério do Desenvolvimento, Indústria e Comércio Exterior. Balança Comercial Brasileira. Dados Consolidados. 2014. Disponível em: <http://www.desenvolvimento.gov.br//arquivos/dwnl_1423144482.pdf>. Acesso em: 18 mai. 2015.

8. Ministério da Administração Federal e Reforma do Estado. Organizações sociais. Cadernos MARE da reforma do estado; v. 2. Brasília: 1998.

9. __ Instituto Brasileiro de Geografia e Estatística. PINTEC 2011. Disponível em:<http://www.pintec.ibge.gov.br/downloads/pintec2011\%20publicacao\%20complet a.pdf>. Acesso em: 01 jun. 2015.

10. BRUM, A. J. O desenvolvimento econômico brasileiro. 18 a ed., Petrópolis e Ijuí: Editora Vozes e Editora Unijuí, 1998.

11. BUAINAIN, A. M. et al (Editores Técnicos). O mundo rural no Brasil do século 21: a formação de um novo padrão agrário e agrícola. Brasília: Embrapa, 2014. 
12. CARVAlHO FILHO, J. S. Manual de Direito Administrativo. 28a ed., São Paulo: Editora Atlas, 2015.

13. CASTRO, M. F. Novas perspectivas jurídicas sobre a reforma de políticas públicas no Brasil. Revista de Direito da Universidade de Brasília, v. 01, n. 01, p. 32-64, junho de 2014.

14. CHANG, H. The political economy of industrial policy in Korea. Cambridge Journal of Economics, n. 17, p. 131-157, 1993.

15. DI PIETRO, M. S. Z. Parcerias na Administração Pública: concessão, permissão, franquia, terceirização, parceria público-privada e outras formas. 9a ed., São Paulo: Editora Atlas, 2012.

16. FERREIRA DA ROCHA, S. L. Terceiro Setor. 2- ed., São Paulo: Malheiros, 2006.

17. FREITAS, J. Sustentabilidade. Direito ao Futuro. 2a ed., Belo Horizonte: Fórum, 2012.

18. . O controle dos atos administrativos e os princípios fundamentais. $5^{\mathrm{a}}$ ed., São Paulo: Malheiros, 2013.

19. FUERLINGER, G.; FANDL, U.; e FUNKE, T. The role of the state in the entrepreneurship ecosystem: insights from Germany. Triple Helix (2015) 2:3. Disponível em: <https://triplehelixjournal.springeropen.com/articles/10.1186/s40604014-0015-9>. Acesso em: 18 jul. 2016.

20. GRAU, E. R. A Ordem Econômica na Constituição de 1988. Interpretação e Crítica. 16a ed., São Paulo: Malheiros Editores, 2014.

21. HAYEK, F. A. The Use of Knowledge in Society. In: Individualism and Economic Order. Chicago: The University of Chicago Press, 1980.

22. HUNT, E. K. História do Pensamento Econômico: Uma perspectiva crítica. Rio de Janeiro: Elsevier, 2005.

23. JUSTEN FILHO, M. Comentários à Lei de Licitações e Contratos Administrativos. 15- ed., São Paulo: Dialética, 2012.

24. KENNEDY, D. Some Caution about Property Rights as a Recipe for Economic Development. Accounting, Economics, and Law, v. 1, n. 1, 2011.

25. KNIGHT, F. Risco, Incerteza e Lucro. Rio de Janeiro: Expressão e Cultura, 1972. 
26. LA PORTA, R. et al. Law and Finance. Journal of Political Economy, v. 106, n. 6, 1998.

27. LESSA MATTOS, P. T. O sistema jurídico-institucional de investimentos públicoprivados em inovação no Brasil. Revista de Direito Público da Economia - RDPE, Belo Horizonte, ano 7, n- 28, p. 101-126, out./dez. 2009.

28. MARQUES, C. L. Da Ciência e Tecnologia. In: GOMES CANOTILHO, J. J.; MENDES, G. F.; SARLET, I. W.; STRECK, L.L. (Coord. Técnicos); LEONCY, L. F. (Coord. Executiva). Comentários à Constituição do Brasil. São Paulo: Saraiva/Almedina, 2013.

29. MARQUES, C. L.; CAVALLAZZI, R.; MIRAGEM, B. Da Ciência e Tecnologia. In: GOMES CANOTILHO, J. J.; MENDES, G. F.; SARLET, I. W.; STRECK, L.L. (Coord. Técnicos); LEONCY, L. F. (Coord. Executiva). Comentários à Constituição do Brasil. São Paulo: Saraiva/Almedina, 2013.

30. MATTEI, L. Gênese e agenda do novo desenvolvimentismo brasileiro. Revista de Economia Política, vol. 33, n- 1 (130), p. 41-59, janeiro-março/2013.

31. MAZZUCATO, M. O Estado Empreendedor. Desmascarando o mito do setor público vs. setor privado. São Paulo: Portfolio Penguin, 2014.

32. MAZZUCATO, M.; PENNA, C. The Brazilian Innovation System: A MissionOriented Policy Proposal. Brasília: Centro de Gestão e Estudos Estratégicos, 2016.

33. MELlo, C. C. O fomento da Administração Pública. Belo Horizonte: Del Rey, 2003.

34. MUSACCHIO, A.; LAZZARINI, S. G. Reinventando o Capitalismo de Estado. O Leviatã nos negócios: Brasil e outros países. São Paulo: Portfolio Penguin, 2015.

35. NORTH, D. Institutions, Institutional Change and Economic Performance. Cambridge: Cambridge University Press, 1991.

36. OCDE - ORGANIZAÇÃO PARA COOPERAÇÃO E DESENVOLVIMENTO ECONÔMICO. Manual de Oslo. Proposta de Diretrizes para Coleta e Interpretação de Dados sobre Inovação Tecnológica. FINEP, 2004. Disponível em: <http://www.finep.gov.br/images/a-finep/biblioteca/manual_de_oslo.pdf >.Acesso em: 25 mai. 2015.

37. ORGANIZAÇÃO DAS NAÇÕES UNIDAS. Transformando Nosso Mundo. A Agenda 2030 para o Desenvolvimento Sustentável. 2015. Disponível em: <http://nacoesunidas.org/wp-content/uploads/2015/10/agenda2030-ptbr.pdf >. Acesso em: 20 nov. 2015. 
38. PARGENDLER, M. Evolução do Direito Societário. Lições do Brasil. São Paulo: Saraiva, 2013.

39. POLANYI, K. A Grande Transformação. As origens de nossa época. $2^{2}$ ed. Rio de Janeiro: Elsevier, 2012.

40. POLIDO, F.; ROSINA, M.; GUIMARÃES CÉSAR, P. Propriedade intelectual: potencialidades e fragilidades do ambiente jurídico-institucional brasileiro para inovação. In: SCHAPIRO, M. G.; TRUBEK, D. (orgs). Direito e Desenvolvimento. Um diálogo entre os BRICS. São Paulo: Saraiva, 2012.

41. RIPERT, G. Aspectos Jurídicos do capitalismo moderno. Campinas: Red Livros, 2002.

42. RODRIK, D. Industrial Policy for the Twenty-First Century. Harvard University. Faculty Research Working Papers Series, novembro/2004. Disponível em: <http://ssrn.com/abstract=617544>. Acesso em: 20 mai. 2015.

43. SCHAPIRO, M. G. Repensando a relação entre Estado, Direito e Desenvolvimento: os limites do paradigma Rule of Law e a relevância das alternativas institucionais. Revista Direito GV, São Paulo, jan-jun 2010.

44. _. Banco de desenvolvimento, regulação e autorregulação: complementaridade regulatória no mercado brasileiro de capital de risco. In: SCHAPIRO, M. G.; TRUBEK, D. (orgs). Direito e Desenvolvimento. Um diálogo entre os BRICS. São Paulo: Saraiva, 2012.

45. SCHAPIRO, M. G.; TRUBEK, D. Redescobrindo o Direito e Desenvolvimento: experimentalismo, pragmatismo democrático e diálogo horizontal. In: SCHAPIRO, M. G.; TRUBEK, D. (orgs). Direito e Desenvolvimento. Um diálogo entre os BRICS. São Paulo: Saraiva, 2012.

46. SCHOLZE, S. H. C. (2016). Pesquisa, desenvolvimento e inovação em tecnologias da informação e comunicação: Lei de Informática e incentivos fiscais à luz das novas teorias regulatórias. Tese de Doutorado em Direito, Faculdade de Direito, Universidade de Brasília, Brasília, DF, 270 p.

47. SCHUMPETER, J. A. Capitalism, Socialism and Democracy. 3- ed., New York: Harper Perennial Modern Thought, 2008.

48. TEIXEIRA, N. O Mercado de Capitais Brasileiro à Luz de seus Avanços e Desafios. In: BACHA, E. L.; OLIVEIRA FILHO, L. C. (Orgs.). Mercado de Capitais e 
Crescimento Econômico, Rio de Janeiro / São Paulo: Contracapa Livraria / Anbid, 2007.

49. WALDO, D. The Administrative State. A Study of the Political Theory of American Public Administration. New Brunswick (USA): Transaction Publishers, 2007.

50. WILSON, E. J. The Information Revolution and Developing Countries. Cambridge, Massachusetts: The MIT Press, 2006.

51. WORLD BANK GROUP. About Doing Business. Disponível em: <http://www.doingbusiness.org/about-us>. Acesso em: 20 nov. 2015. 